UNIVERSIDADE DE SÃO PAULO

ESCOLA DE ENFERMAGEM

SORAYA EL HAKIM REIS

A VIVÊNCIA DE MULHERES GRÁVIDAS MORADORAS EM UMA INSTITUIÇÃO SOCIAL E DE SAÚDE

São Paulo

2007 


\title{
A VIVÊNCIA DE MULHERES GRÁVIDAS MORADORAS EM UMA INSTITUIÇÃO SOCIAL E DE SAÚDE
}

\author{
Tese apresentada ao Programa de Pós- \\ Graduação em Enfermagem da Escola de \\ Enfermagem da Universidade de São \\ Paulo para a obtenção do título de Doutor
}

Orientadora:

Prof $^{\mathrm{a}}$. Dra . Isabel Cristina Bonadio

São Paulo

2007 
Reis, Soraya El Hakim.

A vivência de mulheres grávidas moradoras em uma instituição social de saúde. / Soraya El Hakim Reis. - São Paulo, 2007.

$135 \mathrm{p}$.

Tese (Doutorado) - Escola de Enfermagem da Universidade de São Paulo.

Orientadora: Prof. ${ }^{a}$ Dr. ${ }^{a}$ Isabel Cristina Bonadio.

1. Assistência pré-natal 2. Fenomenologia 3. Enfermagem materno-infantil 4. Serviços de saúde materna I. Título. 


\section{DEDICATÓRIA}

A todas as mulheres do Alojamento Social do Amparo Maternal, que contribuíram com muito carinho para a realização deste estudo, e que me fizeram lembrar que o sonho não deve morrer...

À Madre Domineuc, pela luta, coragem e dedicação na construção do Amparo Maternal, deixando seus sucessores, personificados nos profissionais, que ainda hoje atuam para manter os ideais de sua fundadora, assim, possibilitando a realização desta pesquisa. 


\section{AGRADECIMENTOS}

A meus filhos Guilherme e Mariane, a quem não canso de dizer o quanto os amo, e que sempre estarão em primeiro lugar em minha vida.

A minha família, por entender todos os momentos em que estive ausente.

À Professora Doutora Isabel Cristina Bonadio, pela orientação deste trabalho, pelo seu entendimento nos momentos em que precisei atender à solicitação de meus filhos, deixando de cumprir algumas tarefas determinadas.

À Professora Doutora Maria Alice Tsunechiro, pela confiança depositada.

À Professora Doutora Miriam Aparecida Barbosa Merighi, pela orientação precisa e segura na definição do referencial teórico de Alfred Schütz que fundamentou este estudo.

À Diretoria Executiva e a todos os funcionários do Amparo Maternal, especialmente, a enfermeira obstétrica Eneida de Fátima Pereira de Araújo, a auxiliar de enfermagem Vera Lúcia Duarte de Lima e as escriturarias Maria do Carmo Silva e Tatiane Maria Paiva pelo carinho e atenção.

A todas as assistentes sociais que contribuíram diretamente com este estudo, oferecendo-me as informações necessárias sobre o Alojamento Social.

Ao Departamento de Enfermagem Materno-Infantil e Psiquiátrica da EEUSP, pela oportunidade de realizar este sonho. 
Reis SEH. A vivência de mulheres grávidas moradoras em uma instituição social e de saúde. São Paulo; 2007. 135 p. [Tese]. São Paulo (SP): Escola de Enfermagem da USP; 2007.

\section{RESUMO}

Estudo qualitativo, realizado no Amparo Maternal, maternidade social do Município de São Paulo que oferece alojamento e atendimento à saúde para gestantes em situação de risco social. O objetivo foi compreender como as mulheres vivenciam o processo gravídico e o cuidado de saúde morando nessa instituição. O depoimento de dez mulheres foi obtido por meio de entrevista fenomenológica, com as seguintes questões: qual era sua expectativa ao vir para cá? Como é viver aqui neste período, estando grávida? Como está sendo o cuidado à saúde que você recebe? Foi como você esperava? O que você pretende fazer quando for embora? O referencial teórico da fenomenologia social de Alfred Schütz foi usado. A análise dos depoimentos resultou nas subcategorias que convergiram para quatro categorias concretas do vivido: buscando soluções, o dia-a-dia no Alojamento Social do Amparo, o cuidado à saúde no Amparo Maternal e retornando ao cotidiano com novos projetos. A análise das categorias concretas permitiu a compreensão do tipo vivido mulheres que vivenciaram o processo gravídico, morando em uma instituição social e de saúde, como aquele grupo social que, buscando soluções, procurou acolhimento e mudança na condição de vida, vivenciou o dia-a-dia no Alojamento Social do Amparo, conviveu positiva e negativamente com a experiência do outro, julgou-se em casa, mas também sentiu solidão, privação da liberdade e percebeu possibilidades de aprendizado. No que diz respeito à experiência do cuidado de saúde, vivenciou-a positivamente, considerou que a atenção recebida no parto foi de qualidade, superou as expectativas e pôde criticar o cuidado oferecido. Após vivenciarem o dia-a-dia na instituição, pretendem retornar ao cotidiano com novos projetos. Os resultados obtidos revelaram a importância do Amparo Maternal que atende mulheres grávidas em situação de risco social atenuando angústia, incerteza e medo que podem influenciar os indicadores biológicos de saúde e proporcionar condições reintegração social.

Descritores: gestante, condição social, assistência social, cuidado de enfermagem,

pesquisa qualitativa. 
Reis SEH. Pregnant women experience at a social and health institution. São Paulo; 2007. 135 p. Dissertation (Doctorate) - Escola de Enfermagem. Universidade de São Paulo.

\begin{abstract}
Qualitative study, carried through at the Amparo Maternal, a social maternity of the City of São Paulo that offers lodging and health assistance for pregnant women in social risk situation. The purpose was to understand how the women deeply live the pregnancy process and the health care when they live in this institution. The deposition of ten women was gotten using a phenomenological interview, with the following questions: what were your expectations when you came to this institution? How is to live in this institution, being pregnant? How is the health care that you are receiving? Was it what you expected? What do you intend to do when you leave the institution? The theoretical framework was Alfred Schütz social phenomenology. The depositions analysis resulted in the subcategories converged to four concrete categories of experienced: searching solutions, daily life in the Amparo Social in Amparo Maternal, health care in Amparo Maternal overcamed the espectations and coming back to the daily activities with new projects. The concrete categories analysis allowed to understand the experienced type women who lived the pregnancy process, living in a social and health institution, as the social group which, searching for solutions, looked for shelter and change in the life condition, lived the daily life at the Amparo Social in Amparo Maternal, coexisted negative and positively with the experience of other, judged itself at home, but also felt solitude, freedom privation and perceived learning possibilities. Concern to the experience of health care, the social group lived it positively, and they considered that the attention received during the childbirth was of quality and could criticize the offered care. The results disclosed the importance of Amparo Maternal institution for taking care of pregnant women in social risk situation, for attenuating affliction, and uncertain and fear that can influence the biological health indicators and to provide conditions for social reintegration.
\end{abstract}

Keywords: pregnant woman, social conditions, social assistance, nursing care, qualitative research 


\section{SUMÁRIO}

1 A PESQUISADORA E O OBJETO DO ESTUDO............................................... 11

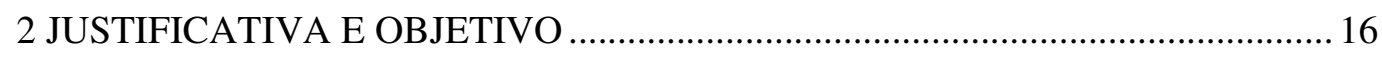

3 O CAMINHO PARA O DESENVOLVIMENTO DA PESQUISA........................28

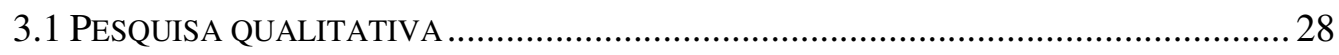

3.2 O REFERENCIAL TEÓRICO-METODOLÓGICO DE ALFRED SCHÜTZ .......................... 30

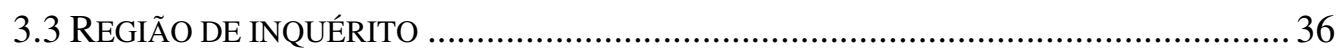

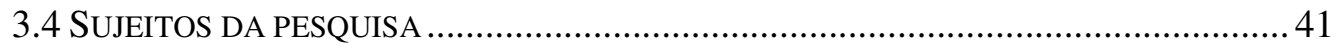

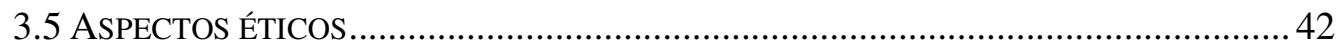

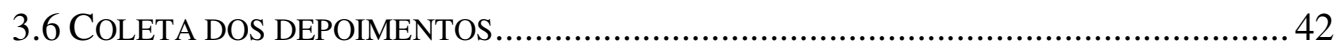

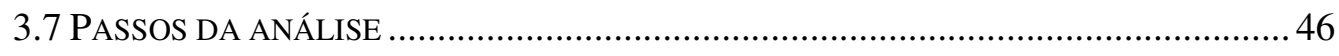

4 AS MULHERES MORADORAS DO AMPARO MATERNAL ........................... 49

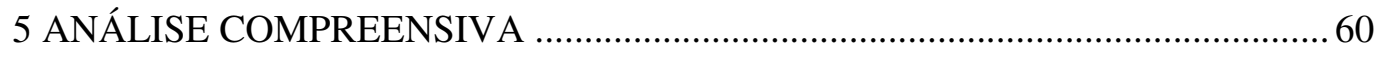

5.1 ESQUEMA DAS CATEGORIAS CONCRETAS DO VIVIDO ...................................... 60

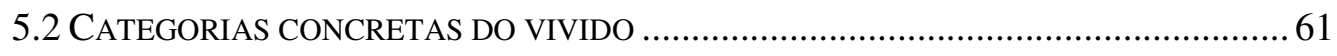

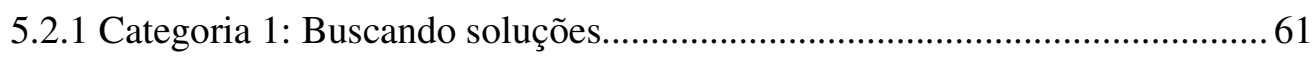

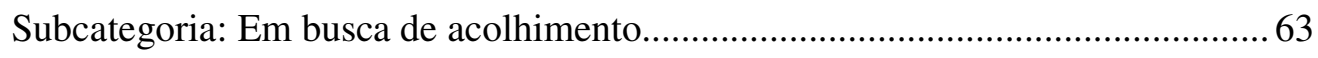

Subcategoria: Querendo mudança na condição de vida...................................... 64

5.2.2 Categoria 2: O dia-a-dia no Alojamento Social do Amparo ........................ 65

Subcategoria: Convivendo positivamente com a experiência do outro .................66 66

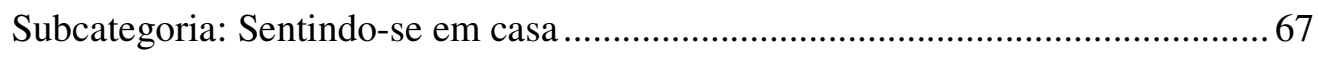

Subcategoria: Convivendo negativamente com a experiência do outro ................ 68

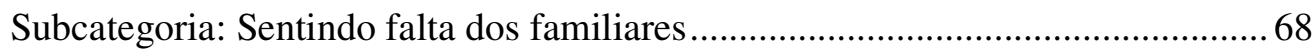




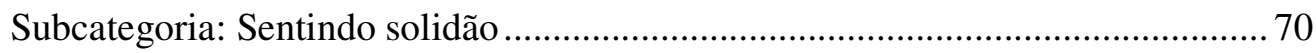

Subcategoria: Sentindo-se privada de liberdade ............................................ 70

Subcategoria: Percebendo receber apoio durante a gestação ................................. 71

Subcategoria: Percebendo a possibilidade de aprendizado ................................. 74

5.2.3 Categoria 3: O Cuidado à saúde no Amparo Maternal ............................... 75

Subcategoria: Vivenciando positivamente a atenção à saúde .............................. 78

Subcategoria: O cuidado à saúde durante a gravidez superando expectativas....... 79

Subcategoria: Qualificando a atenção recebida no parto ................................... 81

Subcategoria: Criticando o cuidado à saúde oferecido .................................... 82

5.2.4 Categoria 4: Retornando ao cotidiano com novos projetos ....................... 83

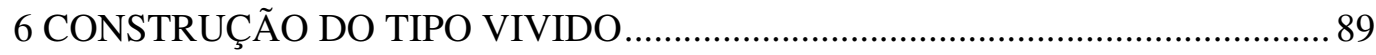

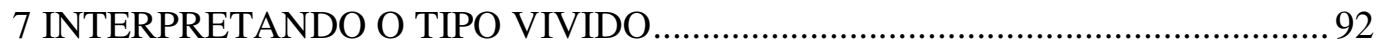

7.1 MULHERES QUE VIVENCIAM O PROCESSO GRAVÍDICO, MORANDO EM UMA

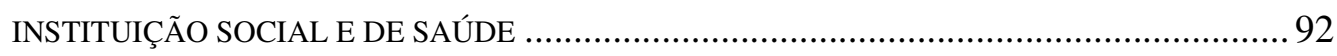

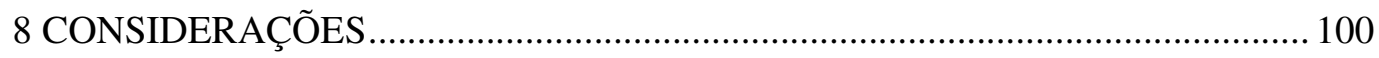

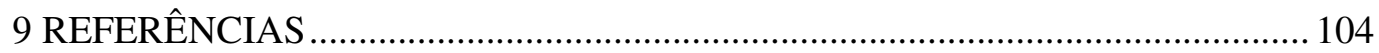

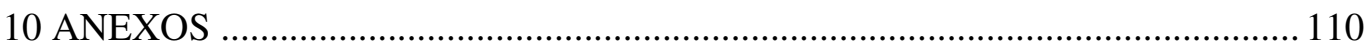


1 A PESQUISADORA

E O OBJETO DO ESTUDO 


\section{A PESQUISADORA E O OBJETO DO ESTUDO}

O interesse em estudar mulheres grávidas, moradoras no Alojamento Social do Amparo Maternal, iniciou-se no decorrer do curso de mestrado. Ao realizar a coleta de dados para a dissertação, tive a oportunidade de observar mais de perto o dia-a-dia dessas mulheres, pois algumas entrevistas aconteceram nesse local.

Em geral as mulheres abrigadas na entidade, caracterizam-se pela gravidez que não foi aceita pelos familiares; são vítimas de violência doméstica; com situação econômica desfavorável; moradoras em outros estados, que vêm a São Paulo na expectativa de obter emprego, e a gravidez inesperada inviabilizou a manutenção de seu vínculo empregatício. Com ausência de vínculo familiar na cidade, ou mesmo, que o possuam, por vários motivos, são impossibilitadas de continuarem morando com os familiares durante a gravidez. Há, também, as moradoras na rua e adolescentes que são encaminhadas pelo Conselho Tutelar.

Após o término do mestrado, continuei integrando a equipe de profissionais do pré-natal desenvolvendo grupos de gestantes, com a finalidade de prepará-las para reconhecerem os sinais e sintomas do trabalho de parto, procurando, assim, a maternidade no momento oportuno. Mantive, também, o atendimento nas consultas individuais, no período da manhã. Até hoje, em uma tarde da semana, supervisiono as atividades de ensino teórico-práticas dos alunos do Curso de Especialização em Enfermagem Obstétrica de uma Universidade privada da cidade de São Paulo. Nesse período, a maior demanda é constituída por gestantes do Alojamento Social do Amparo. 
A situação permitiu-me um contato maior com essa clientela de mulheres, possibilitando, aproximar-me de suas histórias pessoais, como a situação escolar, motivos de abandono da escola, o tipo de trabalho realizado, o relacionamento afetivo, as situações de conflitos sejam elas sociais, emocionais ou econômicos; o dever desempenhado por elas nas relações familiares como filha, mãe, esposa, irmã, neta, sobrinha, amiga, enfim, cada papel exercido por elas no contexto familiar.

Estar disponível para ouvir sobre suas ansiedades e dificuldades decorrentes da gravidez não planejada, mas, muitas vezes aceita e, também, aquelas não aceitas pelas próprias mulheres, companheiros ou familiares favoreceu a formação do vínculo de confiança entre nós. Este após estabelecido proporcionou liberdade às mulheres para relatarem fatos de suas vidas, tais como: os motivos do retorno à instituição, uma vez já terem vivenciado a mesma situação em gestações anteriores; suas expectativas futuras como mãe, alegrias, sonhos em relação a si mesma e ao filho, as preocupações com os outros membros da família, especialmente, com os filhos e todo o contexto social em que vivem. Em conseqüência à gravidez, temporariamente, vêem-se obrigadas a afastarem-se do convívio diário de seu núcleo familiar e social.

Continuar atuando no Pré-Natal do Amparo possibilitou-me, também, conhecer o dia-a-dia dessas gestantes diante das rotinas da instituição, atentando-me para o relacionamento entre elas, considerando as semelhanças e as diversidades do grupo; o olhar pessoal das mulheres em relação às normas e às rotinas estabelecidas pela instituição que, para algumas, têm a conotação de não liberdade, a dinâmica na realização do trabalho diário, as atividades que menos e as que mais gostam de realizar. 
Percebi o relacionamento estabelecido entre as mulheres e os profissionais que participam do atendimento à saúde e à preferência de cada mulher, por alguns profissionais, alertou-me também a relação estabelecida entre nós nos momentos assistenciais, sejam estes individuais ou em grupo, ou quando as mulheres procuramme fora do dia estabelecido para a consulta. Os motivos são diversos, não só relacionados às suas condições de saúde, mas também aos aspectos sociais de cada uma. Sendo assim, não é raro que me procurem para mostrar seus filhos, para relatarem suas experiências como mães e seus planos futuros.

Destacam-se, também, a ansiedade de muitas delas à espera da visita dos familiares, dos amigos e dos pais dos respectivos filhos esperados nos finais de semana. Os motivos particulares que as levam a deixar a instituição por um período e a participação nos momentos festivos. Enfim, inúmeras outras situações do cotidiano de cada mulher que no período gravídico, reside em uma instituição que, simultaneamente, presta atendimento social e de saúde.

Frente a este maior contato com mulheres gestantes do Alojamento Social do Amparo Maternal e minha percepção dos momentos distintos vividos por elas, antes e após irem morar na instituição, temporariamente, foi aumentando meu interesse ao querer atendê-las com maior compreensão de suas experiências.

De certa forma, as histórias de vida dessas mulheres sensibilizam-me e como profissional de saúde questiono-me sobre qual enfoque deve-se prestar atenção, considerando a situação particular que estão vivenciando.

Minha experiência no cuidar dessas mulheres, como enfermeira e docente, ampliaram minhas inquietações a respeito desta temática despertando-me indagações: Como é o cotidiano das mulheres gestantes nesse contexto? Como vivenciam o 
processo gravídico dentro deste particular cenário institucional considerando que, normalmente, a gestação é um período de vulnerabilidade fisiológica e psicológica? Como as mulheres percebem e vivenciam a assistência à saúde que lhes é oferecida na instituição? 
2 JUSTIFICATIVA E OBJETIVO

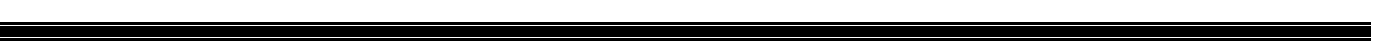




\section{JUSTIFICATIVA E OBJETIVO}

A gestação, o parto e o puerpério são saberes especiais no universo da mulher, do parceiro, da família e de sua comunidade. O processo constitui uma experiência humana das mais significativas, com forte potencial positivo e enriquecedor a todos que dela participam (Brasil, 2001).

A reação da mulher diante da gestação irá depender também do contexto que ela está vivendo, pois fatores sociais, econômicos, familiares e a situação conjugal poderão influenciar na resposta da mulher frente à gravidez.

Inicialmente, a gestação é o desejo de um homem e de uma mulher, e do encontro destes dois desejos nasce um projeto, que é o nascimento do filho. Este projeto fará parte da pré-história desse novo ser. Como ele foi concebido? Em que contexto foi previsto? Ardentemente desejado? Longamente esperado? Foi uma surpresa divina ou uma amarga decepção? Uma fonte de angustia? De euforia? (Szejer, Stewart, 1997). Dependendo da resposta a estas questões, a mulher passa a vivenciar a gravidez de uma determinada maneira.

Diante da confirmação da gravidez, a mulher expressa algumas reações positivas como felicidade e alegria; entre os motivos para estes sentimentos, estão o tempo de espera para engravidar e o desejo de ser mãe (Silva, 1999).

Confirmada a gravidez, a mulher, parceiro e os familiares podem vivenciar diferentes reações diante da novidade. A reação inicial dependerá de ser a gravidez desejada ou planejada ou acidental, não sendo planejada e, até mesmo, indesejada (Bonadio, Tsunechiro, 2006). 
Durante a gestação, sentimentos ambivalentes podem ocorrer como aqueles encontrados por Amazarray, Machado, Oliveira, Gomes (1998), que descrevem a experiência de ser mãe adolescente vivida por jovens que assumiram a gestação. A alegria de ser mãe, sentindo o bebê movimentar-se em seu ventre, só adquiriu seu verdadeiro sentido após a superação da tristeza de se perceber gorda e feia como gestante.

Para a mulher, a gestação pode gerar sentimentos diversos, tais como: surpresa, castigo, prêmio, motivação para continuar a viver, realização de um projeto antigo, competição em família, problema, estorvo, descuido ou irresponsabilidade. O impacto causado pela gravidez dá origem a inúmeras manifestações que vão desde euforia a sentimentos, como: frustração, temor da censura, preocupação com o corpo, rejeição familiar, bem como da sociedade, do marido ou do namorado. Em relação ao contexto biopsicossocial, a necessária mudança de papel leva à incerteza e medo do futuro (Ávila, 1999, Jeneral, 2000).

Não podemos esperar que todo processo de gestação seja de experiências gratificantes no mundo da mulher. Em várias ocasiões, como profissional encontramos situações inversas; portanto, devemos estar preparados para entender cada mulher diante de seus sentimentos, em particular, quando se encontra grávida, sejam eles positivos ou negativos.

Compreender as diferentes reações que as pessoas podem manifestar em relação à gestação nos possibilita não julgar os sentimentos e atitudes da mulher diante desse processo.

No contexto familiar, a chegada de cada filho tem implicações diferentes, pois o nascimento de cada um se dá em momentos e situações distintos. O nascimento 
implica um processo de ajuste e acomodação, tanto individual como familiar podendo ser positivo ou negativo, dependendo da estrutura e funcionamento do sistema familiar (Velásquez, 1997).

A gravidez é uma transição que envolve a necessidade de reestruturação e reajustamento a um novo papel diante de si e da sociedade, esta mudança serve tanto para as primíparas que de filhas passam a ser mães como às multíparas, pois ser mãe de um outro filho é diferente de ser mãe de um único filho (Maldonado, 2000).

Um filho na vida do casal pode ter vários significados, desde um projeto de vida, uma realização, uma auto-afirmação, como também poderá significar um transtorno, um rival, uma ameaça à liberdade; por isso, sentimentos de dúvidas, inseguranças e raiva podem se misturar o tempo todo (Ávila, 1999).

As dúvidas e os sentimentos ambíguos devem ser discutidos com o companheiro, família e profissionais, para que a mulher entenda a naturalidade dos sentimentos diminuindo, assim, sua culpa.

A relação que o parceiro tem com a mulher e com a gravidez contribui para sua aceitação ou rejeição e influencia na forma que ela vai vivenciar as mudanças desse período. Sendo assim, a atitude do parceiro quanto à sua participação neste processo contribuirá para atenuar ou intensificar sentimentos de abandono. A interação por parte dos familiares é de fundamental importância na medida em que cada membro sofre transformação sob o impacto da gravidez (Dessen, Braz, 2000).

Embora alguns pais demonstrem dificuldades em atender a um novo papel paterno, há indícios de uma profunda modificação quanto a seu envolvimento no período da gestação que parece não se encontrar restrita só ao universo feminino. Tal envolvimento é demonstrado com base na preocupação e ansiedade dos pais em 
relação ao apoio material e emocional prestado à gestante (Piccinini, Silva, Gonçalves, Lopes, Tudge, 2004).

Dessen, Braz (2000) descrevem que as mudanças decorrentes do período de transição familiar na gravidez, podem ser experenciadas pela mulher de forma positiva, ou negativa. Dentre as vivências positivas, encontram-se o apoio psicológico, cuidados físicos e as orientações sobre a gravidez, a ajuda financeira nas tarefas domésticas e no cuidado com os filhos e melhoria no relacionamento com o marido e a família. Nas alterações negativas, estão falta do apoio psicológico esperado, afastamento de amigos, dificuldade no relacionamento com o marido e familiares, alteração de humor, afastamento do trabalho e mudanças nas atividades de lazer.

Da mesma forma, Dias e Deslandes (2006) referem que, às mulheres o apoio do companheiro e da família durante a gestação é importante, pois consideram que é um momento de fragilidade emocional e física da mulher. Para elas o apoio se manifesta-se de diversas formas, como o comportamento mais afetivo, pela ajuda nos afazeres da casa e com os outros filhos; ajuda material com o enxoval ou alimentação.

Quando a gravidez é desejada e a mulher pode contar com o apoio e a participação da família favorece o sentimento de felicidade, possibilitando que a gravidez transcorra com mais tranqüilidade emocional (Bonadio, Tsunechiro, 2006).

Nos casos das adolescentes, muitas procuram apoio inicial do companheiro, porém não partem do princípio que é dever do mesmo assumir o filho. A gravidez é tratada como sendo de responsabilidade só delas e, ao se depararem com o abandono, procuram o apoio familiar. Quando a família da adolescente não oferece suporte emocional, poderão desencadear vários problemas associados com o sofrimento 
psíquico, contribuindo com sentimento de negação (Godinho, Schelp, Parada, Bertoncello, 2000; Sabroza, Leal, Souza, Gama, 2004).

O apoio tem a função de interação entre as pessoas ou grupos de pessoas que, por meio do contato sistemático, estabelecem vínculo de amizade e de troca de informação, recebendo ajuda material, emocional e afetiva. O apoio social atua reduzindo o impacto da resposta ao estresse, tanto em seu componente fisiológico como no psicológico. O envolvimento comunitário pode ser um fator psicossocial significativo no aumento da confiança pessoal e satisfação com a vida e da capacidade de enfrentar problemas (Paéz et al, 1986; Valla, 1998).

A dificuldade econômica, a falta de parceiros e de suporte familiar e social são fatores de risco para depressão na gravidez (Zucchi, 1999).

Nas situações de crise, receber ajuda colabora na prevenção e manutenção da saúde, reforça fatores positivos, fortalecendo o indivíduo para a resolução do problemas do cotidiano.

Independente de ser a primeira gestação, adolescente ou não, o apoio familiar é muito importante na vida da mulher grávida, proporcionando suporte emocional, educativo, econômico e social imprescindível nesse período de transição. A família poderá contribuir para a diminuição da ansiedade, angústia e medo durante o processo da maternidade.

Por outro lado, nem sempre a família ou pessoas do contexto social em que a mulher vive consegue dar o suporte necessário no processo da gravidez, pois o desgaste familiar, seja ele de ordem emocional, social ou econômica, impossibilita a relação de ajuda que a mulher precisa. Nesta situação, muitas vezes, as mulheres se 
encontram-se desamparadas, pois não existe uma política de saúde que garanta este suporte.

A dificuldade no convívio familiar é resultado da injustiça social e da miserabilidade em que as estão sujeitas, favorecendo o desequilíbrio das relações e a desagregação familiar (Gomes, Pereira, 2005).

Em conseqüência desta desagregação, muitas vezes, ocorre violência contra a mulher e está inserida na relação dos indivíduos com o mundo das coisas e na relação com o outro e presente em todas as comunidades. Existem vários tipos de violência que são classificadas, como agressão física, sexual, psicológica, social e patrimonial (Caravante, 2000; Alves, Coura-Filho, 2001; Silva, Coelho, Caponi, 2007).

A situação apresentada dificulta o convívio familiar harmonioso resultando em abandono ou afastamento do lar, pela gestante. Nessas condições tornam-se mais vulneráveis a problemas de saúde, apresentando um aumento do índice de mortalidade e morbidade devido à falta de recursos humanos, sociais e fatores de risco, entre eles. As causas de mortalidade estão relacionadas a problemas crônicos de saúde como doenças cardíacas, abuso de substância, alcoolismo e traumas físicos, esta população sofre por discriminação e marginalização (Strehlow, Amos-Jones, 1999; Tuten, Jones, Svikis, 2003).

Ao estudarem as diferentes características de saúde ou mães sem lar, Weinreb, Goldberg, Perloff (1998) fizeram comparações com mães com moradia, sendo ambas de baixa renda, concluíram que as duas populações têm suas condições de saúde agravadas. Os resultados sugerem que mulheres sem lar apresentam maior risco de resultados de saúde adversos, por terem mais vulnerabilidade para HIV, maior possibilidade de doença e maior índice de emergência e hospitalização. Já Bassuk, 
Weinreb, Buckner, Browne, Salomon, Bassuk (1996) concluíram que mães sem lar têm recursos econômicos e suporte social deficientes, estando mais sujeitas aos ataques, violência durante a vida e problemas de saúde mental, tendo a depressão resultado significativo.

A violência é um fenômeno complexo que exige uma inspeção cuidadosa de seus diversos componentes. Castro, Ruiz (2004) referem que a violência emocional durante a gestação está acima da violência física e sexual, pois as mulheres que já sofriam violência física e sexual de seus parceiros antes da gravidez, continuaram sendo agredidas na mesma proporção, porém existe um aumento significativo de mulheres que são agredidas emocionalmente.

Os autores concluíram que a vulnerabilidade psicológica ocorrida durante a gestação, sendo quando agravada pela falta de moradia é percebida no grupo de gestantes que vivencia a gestação fora de seu lar, morando em uma instituição social e de saúde. Na oportunidade de se expressarem no grupo, algumas gestantes citam que a instabilidade emocional própria da gestação é agravada pelos problemas sociais e conflitos familiares que experimentam, tendo como resultado o choro constante, tristeza, sentimento de solidão que geram angústia e carência afetiva.

O estudo de Gomes (1994) mostra que adolescentes moradoras de rua ou que permanecem na rua, porém, com laços familiares e as que estavam em rompimento com a família, de modo geral, sofrem violência sexual, como também gestação precoce indesejada, abortos e doenças sexualmente transmissíveis. Uma proporção muita alta de adolescentes grávidas é resultado de relação sexual forçada por adultos ou membros da família. As mulheres em situação de abuso sexual têm pior saúde física e mental (OPAS, 1998). 
Quando a situação de falta de moradia acontece durante a gravidez, a vulnerabilidade à saúde biopsicossocial é ainda maior, pois envolve, também, as complicações obstétricas, perinatais e neonatais.

Embora a gestação seja uma condição de saúde normal, é um período de vulnerabilidade fisiológica e psicológica para à mulher e ao feto. Quando a mulher engravida e não tem moradia, a situação torna-se particularmente instável. Nesta fase crítica da vida, a mulher precisa de um abrigo adequado para superar esta instabilidade (Killion, 1995).

A mulher desprovida de um lar pode sentir-se fragilizada para enfrentar o mundo e para determinar seu futuro. Entretanto, precisa ter habilidade para perceber que necessita de ajuda, para aceitar a ajuda e tornar-se uma boa mãe (Ovrebo, Ryan, Jackson, Hutchinson, 1994).

O cuidado pré-natal é necessário à saúde da mulher e da criança e para obtenção de resultados adequados; está associado com a redução da mortalidade infantil, incidência reduzida de prematuridade, baixo peso ao nascer e reduzido custo do cuidado intensivo neonatal (Balcazar, Hartner, 1993).

Nas situações em que a mulher encontra-se desprovida de apoio, também, ocorrem complicações e resultados perinatais adversos.

Dentre as complicações, destacam-se corrimento vaginal, cefaléia, infecção do trato urinário, anemia, hipertensão e toxemia. Dentre as doenças sexualmente transmissíveis, as de maior incidência são Clamídia tracomatis, herpes genital, HIV, condiloma, sífilis e Trichomonas vaginalis (Stein, Lu, Gelberg, 2000). Os resultados de um estudo realizado no Chile, nas cidades de Santiago, San Felipe e nos Andes indicaram que a população de mulheres grávidas de nível socioeconômico baixo 
apresentou mais complicações obstétricas, sendo infecção urinária, hipertensão arterial e anemia as mais freqüentes (Alvarado, Medina, Aranda, 2002). O estudo de Rocha, Netto, Priore, Lima, Rosado, Franceschini (2005) realizado em Viçosa, (MG) encontrou $21,4 \%$ de gestantes de baixa renda com anemia, ganho de peso inadequado durante a gestação que se correlaciona com o peso de nascimento.

Os resultados perinatais adversos relevantes, de uma população desprovida de moradia são o baixo peso ao nascer e a prematuridade (Stein, Lu, Gelberg, 2000). Considerando a baixa renda como fator de desigualdade na saúde perinatal, o estudo de Andrade, Szwarcwald, Gama, Leal (2004) demonstrou maior índice de resultados adversos perinatais como baixo peso e mortalidade perinatal na população de baixa renda do Município do Rio de Janeiro.

De modo geral, no Brasil, as mulheres enfrentam uma série de barreiras para obtenção de cuidado pré-natal, particularmente, nas situações de gravidez inesperada, dificuldades econômicas ou quando desprovidas de moradia.

Mulheres grávidas da Florida nos Estados Unidos da América, que não possuem moradia fixa ou vivem em abrigos improvisados, em casa de estranhos, na rua, ou trocam de moradia duas a três vezes no período de um ano enfrentam dificuldades para o cuidado pré-natal. Entre elas, destacam-se o tempo de espera para o atendimento da consulta, distância e transporte (Bloom, Bednarzyk, Devitt, Renault, Teaman, Loock, 2004). Situação semelhante ocorre entre mulheres grávidas da Nicarágua que vivem no campo e procuram ou são encaminhadas as casas maternas em razão da grande distância entre suas moradias e o centro de saúde, para a realização do pré-natal (Guilhermin, Rieubland, Fioretta, Luisier, 1999). 
Estudo realizado entre mulheres afro-americanas de baixa renda, na Califórnia, também aponta a dificuldade de transporte e distância como barreiras para o cuidado pré-natal, incluindo ainda o fato de algumas mulheres não acharem necessário a realização deste cuidado. Outros impedimentos encontrados referem-se ao relacionamento entre o profissional e as mulheres como medo de revelar o uso de certas substâncias tais como bebidas alcoólicas e fumo, medo do exame médico e confirmação da gravidez (Curry, 1990 e Mikhail, 1999).

Além disso, ocorrem preconceitos e julgamentos feitos pelos profissionais de saúde em relação às atitudes da mulher, afastando-a dos cuidados de saúde, que implicando em resultados obstétricos negativos.

Para Killion (1995), as mulheres gestantes sem lar são heterogêneas, embora vivenciem a mesma situação não significa que sejam iguais. Diante disso, as enfermeiras e toda equipe multidisciplinar devem ter um repertório de estratégias e alternativas para que o cuidado seja individualizado.

Entendo que as mulheres abrigadas no Alojamento do Amparo Maternal encontram-se em situação de vulnerabilidade social, afetiva e econômica associada à gestação e com necessidades diferenciadas. Por isso, para o cuidado à saúde demandam ações distintas.

Investigar e compreender a vivência de mulheres no processo gravídico como moradoras temporárias em uma instituição social e de saúde, resultará em subsídios para proposição de ações específicas no cuidado à saúde materna que envolvam os âmbitos biológico, psicológico e social. Medidas que atenuem angústias, tensões, incertezas e medos podem influenciar os indicadores biológicos de saúde e, também, proporcionar condições de reintegração social a essas mulheres. 
Desta forma, senti a necessidade de buscar a significação neste fenômeno definindo os seguintes objetivos para esta investigação:

Compreender como as mulheres vivenciam o processo gravídico, morando em uma instituição social e de saúde;

Compreender a vivência dos cuidados de saúde dessas mulheres durante esse período de suas vidas. 
3 O CAMINHO PARA O DESENVOLVIMENTO DA PESQUISA 


\section{O CAMINHO PARA O DESENVOLVIMENTO DA PESQUISA}

\subsection{Pesquisa Qualitativa}

Este estudo trata da experiência de mulheres que vivenciam o processo gravídico morando em uma instituição social e de saúde. Portanto, a escolha metodológica para investigar, descrever e compreender esta particular realidade social recai sobre a pesquisa qualitativa.

O estudo qualitativo é definido como aquele que se desenvolve numa situação natural, é rico em dados descritivos, tem um plano aberto e flexível e focaliza a realidade de forma complexa e contextualizada. Busca na realidade informações e dados que possam ser manipulados cientificamente, permitindo sua melhor compreensão. Os dados são, sobretudo, “construídos” e não apenas “colhidos”, pois esta abordagem parte do fundamento de que há uma relação dinâmica entre o mundo real e o subjetivo, uma interdependência viva entre o mundo objetivo e a subjetividade do sujeito (Bogdan, Taylor, 1984; Lüdke, André, 1986; Chizzotti, 2003; Demo, 2004).

Dentre as modalidades da pesquisa qualitativa, a fenomenologia possibilita a investigação do cotidiano para explicar a realidade concreta. A fenomenologia é o estudo ou a ciência do fenômeno, aqui entendido como tudo aquilo que se mostra ou aparece. O termo fenomenologia deriva de duas outras palavras, de raiz grega: Phainomenon, aquilo que se mostra a partir de si mesmo e logos ciência ou estudo. Esta ciência estuda a realidade cognitiva incorporada aos processos da experiência humana subjetiva, possibilitando a compreensão do fenômeno em função das 
experiências vividas e do mundo cotidiano (Wagner, 1979; Moreira, 2002, Dartingues, 2005).

$\mathrm{Na}$ fenomenologia, o sujeito e objeto não se distingue radicalmente, o que conta é distingue radicalmente o sujeito e o objeto, o que conta é a relação intencional entre os dois, portanto, o sujeito que está em relação com o objeto (Bello, 2004).

Todas as experiências diretas de seres humanos são experiências “em e de seu mundo da vida". O mundo da vida é simplesmente toda a esfera das experiências cotidianas do homem. Viver no mundo da vida cotidiana significa conviver em envolvimento interativo com muitas pessoas, em complexas redes de relacionamentos sociais.

O homem nasce em um mundo onde se relaciona com seus semelhantes, dá conta de sua existência, não questiona, apenas vivencia. O compartilhar com o outro as experiências é o modo que o indivíduo situa-se no mundo. Por meio da intersubjetividade é que ele conhece o mundo do outro e vice-versa, portanto, o mundo da vida não é privado e, sim, compartilhado, experimentado e interpretado por outros, sendo assim, vivenciam o mundo comum. O homem assume uma "atitude natural", que significa a postura natural frente aos problemas diários. (Schütz, 1974a; Wagner, 1979).

A experiência de mulheres, que vivem o processo gravídico, moradoras no Amparo Maternal, instituição social e de saúde, embora seja singular, elas não a vivenciam sozinhas, compartilham seus conhecimentos com outras. Deste modo, podem situar-se no mundo.

$\mathrm{Na}$ busca pela compreensão do fenômeno - a realidade concreta de mulheres que vivenciam o processo gravídico morando no Amparo Maternal - entendendo que 
ele não é individual, mas de um grupo de pessoas que o vivencia em um mesmo contexto social, ou seja, morando em uma instituição social e de saúde, compreendi ser adequado utilizar o referencial da fenomenologia social de Alfred Schütz.

Apropriei-me desse referencial para compreender, como as mulheres vivenciam o processo gravídico e quais são as experiências do cuidado de saúde, estando privadas do convívio familiar. Lembro que o referencial de Alfred Schütz busca a vivência do cotidiano dos sujeitos que interagem e se compreendem no mundo social, como também os motivos de suas ações, sendo assim, este referencial é apropriado para responder aos objetivos deste estudo.

\subsection{O REFERENCIAL TEÓRICO-METODOLÓGICO DE ALFRED SCHÜTZ}

Quando observo o grupo social de mulheres moradoras em uma instituição social e de saúde, estou percebendo um de seus aspectos, pois é isto que é me dado. Tenho consciência do que efetivamente é mostrado, mas percebo também que existem aspectos que não são dados que tenho a intenção de investigar, isto é, ir além do que é dada a minha consciência.

A abordagem fenomenológica da sociologia compreensiva de Alfred Schütz dará suporte à compreensão da realidade social de um grupo de mulheres moradoras temporárias em uma instituição social e de saúde, dentro do mundo-vida.

Alfred Schütz nasceu em Viena na Áustria, em 1899. Estudou direito e ciências sociais na própria cidade em que nasceu. Em razão da ameaça de ocupação da Áustria pelos nazistas, emigrou para Paris em 1938. Um ano depois chega aos Estados 
Unidos da América, onde ingressa na Universidade e fundou a Sociedade Internacional de Fenomenologia.

The Phenomenology of the Social World, título traduzido para o inglês, é o único estudo que Schütz publicou enquanto ainda vivia na Europa. Foi nos Estados Unidos da América que começou sua carreira como escritor, com o ensaio "Phenomenology and the social sciences", ao todo foram 32 títulos, a maioria, em inglês. Alfred Schütz morre em Nova York em 1959 (Wagner, 1979).

Durante os anos de estudo, teve grande interesse pelo trabalho de Edmund Husserl e Max Weber. Sucintamente, descrevo as posições destes dois estudiosos que constituíram a base do pensamento de Schütz.

Husserl nasceu em 8 de abril de 1859, na cidade de Prossnitz, Moravia, pertencente ao império Austro-Húngaro, hoje República Tcheca. Iniciou sua carreira como professor, na Universidade de Berlim. Foi o primeiro a conceber e a divulgar a fenomenologia, como a ciência das estruturas essenciais da consciência pura, como também propôs o método fenomenológico de investigação filosófica.

Para Husserl, seu ponto de partida são as experiências do ser humano consciente, que vive e age em um "mundo" que ele percebe, interpreta e que faz sentido para ele. A intencionalidade é um ponto forte na fenomenologia, é a característica da consciência de ser consciente a algo. É a consciência intencional que faz o mundo aparecer como fenômeno (Wagner, 1979; Moreira, 2002).

Max Weber nasceu na Alemanha em 21 de abril de 1864. Em 1882, começou o estudo superior, dedicando-se simultaneamente à economia, à história, à filosofia e ao direito. Define a sociologia como sendo uma ciência que tenta compreender de modo interpretativo a ação social e por meio desta explicá-la causalmente em termos de 
curso e efeito. O relacionamento social é descrito por ele como a conduta de várias pessoas que, conforme um dado contexto de significado, se dirigem e orientam umas com relação as outras (Wagner, 1979).

O trabalho de Schütz pode ser considerado a síntese de Husserl e Weber, porém este resumo foi realizado, após longos processos de seleção, adaptação e modificação de componentes relevantes das teorias de ambos. Portanto, como pensador tinha o propósito de estabelecer os fundamentos de uma sociologia fenomenológica. Ele confrontou a filosofia não com a sociologia como um todo, mas como uma visão sociológica: a sociologia da ação e compreensão de Max Weber (Wagner, 1979).

$\mathrm{O}$ conceito do mundo vida foi elaborado e aos poucos incorporado à terminologia filosófica. O mundo da vida tem como conceito um universo empírico, descritível e como o mundo das vivências, ações e escolhas (Stein, 2004).

O homem está situado no mundo da vida, e neste mundo ele deve agir (Capalbo, 1979).

Na relação face a face tenho experiência imediata de meu semelhante. E esta é vivenciada em diversos níveis de intimidade, porém qualquer que seja a diferença e distanciamento com o outro, a experiência face a face é essencialmente direta (Schütz, 1974b).

$\mathrm{Na}$ relação face a face que a vida de meu semelhante aparece melhor para mim, pois é nesta relação de reciprocidade que melhor percebo tudo o que o outro quer exprimir consciente e explicitamente. No entanto, há gestos, entonação de voz e outros índices que ele não coloca claramente, mas que me mostram, e que fazem parte das indicações que posso ter de sua consciência (Capalbo, 1979). 
No mundo intersubjetivo, para o homem da atitude natural que vive sua vida cotidiana, é coisa certa e evidente que há outros seres humanos que são dotados de inteligência, sentimentos, e que são capazes de conhecer e de agir (Capalbo, 1998).

Cada indivíduo se situa na vida de uma maneira específica. O mundo é transposto ao mundo do sujeito de acordo com os elementos significativos de sua situação biográfica. Nascer no mundo significa nascer de um pai e de uma mãe, que nos são exclusivos, ser criados por adultos contribui para nossa bagagem de conhecimento e estar no mundo significa estar situado biograficamente com os seus semelhantes (Schütz, 1974a).

Durante a trajetória do homem no mundo, ele adquiriu conhecimento por meio de suas experiências vividas, como também de seus familiares, mestres e de pessoas mais velhas, este conhecimento adquirido é denominado por Schütz de bagagem de conhecimento disponível. Desta bagagem de conhecimento fazem parte as recomendações de comportamento social, herança e tradição, hábitos adquiridos, o que aprendemos e também, o que esquecemos, mas que podem ser reativados (Capalbo, 1998).

O homem usa seu estoque de conhecimento como um código de interpretação de suas experiências passadas, presentes e futuras. A experiência em curso pode ser identificada como um conhecimento anterior, igual que se repete ou que seja modificado, ou ainda, como uma experiência de um tipo semelhante a alguma outra já identificada, ou experiência em curso aparece como estranha (Wagner, 1979).

Se investigarmos os impulsos subjetivos por trás da ação humana, iremos encontrar a teoria da motivação. Para Bello (2004), os homens agem em função de motivações dirigidas a objetivos que apontam para o futuro, denominadas por Schütz 
de motivo a fim de ou motivos para. Por outro lado, os homens têm razões para suas ações e preocupam-se com elas. Estas razões estão enraizadas em experiências passadas. Schütz denominou-as de motivos por que (Wagner, 1979).

As coisas sociais só são compreensíveis, se puderem ser reduzidas à atividade humana, e esta será compreensível somente mostrando os motivos para e os motivos por que (Schütz, 1974b).

Qualquer momento da vida prática de um homem não se esgota em uma situação específica, contendo limitações, condições e oportunidades com relação a seus objetivos, esta situação é apenas um episódio na corrente de sua vida. Sua posição diante dela é de uma pessoa que atravessou toda uma longa cadeia de experiência de vidas anteriores, sendo exclusiva do homem. Assim sendo, duas pessoas jamais poderiam vivenciar a mesma situação do mesmo modo (Wagner, 1979).

Entendo que cada mulher moradora no Amparo Maternal vivencia esta situação como sendo única, singular, daquele momento e que faz parte de sua história de vida. Este grupo de mulheres, embora vivendo experiências específicas possui reciprocidade entre elas que merece ser buscada pelos profissionais. No mundo da vida diária, o homem sempre tem um estoque de conhecimento que lhe serve como código de interpretação de suas experiências passadas e presentes e, também, determina sua antecipação das coisas que virão.

O intuito desta pesquisa é conhecer a realidade de mulheres que vivenciam o processo gravídico situando-as na atitude natural, portanto, em seu mundo vida, para compreender as diversas práticas interpretativas por meio das quais a realidade é construída na perspectiva pessoal e social. A compreensão dessas práticas 
interpretativas, por meio das quais a realidade é constituída, é expressa por ações socialmente vividas, tanto individual como coletivamente, sendo estas ações intencionais de significados subjetivos.

$\mathrm{Na}$ relação social, os atores desempenham tipos que não são vistos individualmente, pois se relacionam dentro de um grupo social; sendo assim, o comportamento vivido dos atores sociais apresenta características típicas daquele grupo social. Neste sentido pretendo por meio da compreensão do comportamento social de mulheres que vivem a mesma experiência, ou seja, que estão vivendo o processo gravídico morando em uma instituição social e de saúde, construir o tipo vivido deste grupo.

$\mathrm{Na}$ vida cotidiana realizamos tipificações, mas isto não modifica nossa atitude em relação à vida e às suas exigências práticas. Não somos tipos fixados, há uma margem de liberdade, sendo assim podemos parar de desempenhar o papel que o tipo nos havia imposto. A tipificação possibilita a apreensão da consciência do outro, que não é apenas apreensão individual, porque vivemos com outro na relação social. É a partir da análise das relações sociais que chegamos ao tipo vivido (Capalbo,1979; Merighi, 2000).

Para compreender as experiências vividas pelas mulheres no Amparo e seu significado, investiguei suas ações a partir do seu mundo-vida e suas interações dentro do mundo social, desvelando os motivos para e os motivos por que de suas ações. As ações sociais dessas mulheres não estão só vinculadas a um passado, mas direcionamse a um futuro, e o significado atribuído por elas às suas ações está baseado na situação biográfica de cada uma, ou seja, em sua bagagem de conhecimento 
disponível. Portanto, compreender as ações destas mulheres, só será possível mediante o significado que elas conferirem a suas ações.

A ação é definida como uma conduta que é prevista, isto é, baseada em um projeto preconcebido pelo ator de maneira consciente. Toda ação manifestada é ao mesmo tempo projetada e dotada de propósito (Schütz, 1974a; Wagner, 1979).

Todo projetar consiste na antecipação do comportamento futuro, ao fantasiar uma ação visualizo antecipadamente o ato que estou projetando, como se já tivesse sido efetuado, ou seja, completado (Schütz, 1974a).

Wagner (1979) esclarece ser preciso distinguir se há ou não no projeto uma intenção de realizá-lo, pois a intenção transforma a previsão e um objetivo e o projeto em propósito. Se faltar uma intenção de realização, a ação projetada permanece uma fantasia.

A caracterização do grupo social das mulheres estudadas, que Schütz denominou de tipificação, irá emergir da descrição do comportamento social das mulheres que vivenciaram o processo gravídico no contexto de uma situação social morando no Alojamento Social do Amparo.

\subsection{REGIÃO DE INQUÉRITO}

Antes, de definir melhor o objeto da pesquisa e a metodologia a ser utilizada, senti a necessidade de explorar um pouco mais o cenário da pesquisa, pois acreditava que poderiam surgir outras questões. Diante desta necessidade, contatei uma das assistentes sociais da instituição, para acompanhar mais de perto o cotidiano das mulheres acolhidas, como também tomar ciência de seus direitos e deveres, suas 
atividades diárias, e a relação que outros profissionais e voluntários estabelecem com elas.

Este contato facilitou descrever o cenário da pesquisa, definir o objeto do estudo, como também a entrada no campo de pesquisa e conhecer os locais a serem observados na coleta de dados.

O objeto ou o caso da pesquisa foi definido como sendo a experiência vivida por mulheres gestantes morando, temporariamente, em uma instituição social.

O Amparo Maternal, instituição filantrópica, foi fundado por representante da igreja católica em 20 de agosto de 1939, teve como personagem principal Madre Marie Domineuc. O objetivo da fundação da instituição era atender as mulheres gestantes sem teto, moradoras nas ruas de São Paulo. No início, o Amparo existia na própria Clínica Obstétrica do Hospital São Paulo e, já em seu primeiro ano, 400 gestantes foram abrigadas em casas alugadas próximo ao hospital, No momento do parto as gestantes eram encaminhadas às maternidades próximas, principalmente ao Hospital São Paulo. Como o número de mulheres que necessitavam de amparo, aumentava, em consonância ao crescimento da cidade, iniciaram-se as gestões na prefeitura que, em vista da obra inédita, resolveu construir o prédio com a única finalidade de servir como alojamento social, que demorou 20 anos para ser construído. No início da década de 1960, o Amparo Maternal encontrava dificuldade para conseguir atendimento para suas gestantes, pois elas não possuíam direito previdenciário, sendo assim as instalações do prédio em construção foram adaptadas para iniciar o funcionamento do serviço hospitalar de obstetrícia. A partir de 1964, o Amparo Maternal tornou-se, então, a única entidade médica social existente no Brasil (Bonadio, 1996). 
A seguir os dados foram obtidos por meio de informação das assistentes sociais e de voluntárias, e pela minha vivência profissional e como aluna da pósgraduação, atuando no pré-natal da instituição, desde 2001.

As gestantes que procuram a instituição são encaminhadas ao alojamento social que, atualmente, tem capacidade para abrigar 100 mulheres entre gestantes e puérperas e 24 recém-nascidos, que receberão assistência à saúde durante a gravidez, parto e puerpério.

Quando as gestantes procuram o alojamento social do Amparo, sozinhas ou acompanhadas, passam por uma triagem com a assistente social cujo objetivo é identificar os motivos para a procura do mesmo. Em seguida, é preenchido um formulário para obtenção de dados pessoais como nome, idade, endereço, grau de instrução, breve histórico sobre gestações anteriores destacando o número de filhos e a responsabilidade sobre os mesmos. Dando continuidade a este primeiro contato, as mulheres gestantes recebem explicações sobre as normas gerais, obrigações e direitos. Dentre as normas gerais as gestantes ficam cientes dos horários estabelecidos pela instituição no que diz respeito às visitas; ao momento de maior silêncio nos quartos; à possibilidade de saídas rápidas; ligações telefônicas; horário do banho e refeições; exigência de saída do quarto pela manhã. Entre as obrigações, é estabelecido que as gestantes cumpram com o uso obrigatório do crachá de identificação; tenham sempre consigo documentos e o cartão do pré-natal; participem na escala para a limpeza dos quartos, não levam comida para os quartos, nem circulem na área da maternidade, participarem da organização do quarto, não usem telefone celular, preparem os pertences de uso pessoal e para o recém-nascido para a internação para o parto, efetuem o registro do recém-nascido por ocasião da alta hospitalar. Em relação a seus 
direitos, as mulheres gestantes recebem abrigo, apoio afetivo, emocional, social, material, alimentação adequada; assistência à saúde durante o pré-natal, parto e puerpério; atividades de lazer, capacitação profissional e suporte religioso.

Após a leitura e orientações das normas e rotinas, a gestante assina o documento no qual afirma estar ciente das informações. Em seguida, é encaminhada para confecção do crachá de identificação e para o quarto, onde recebe um Kit de higiene pessoal e complemento do vestuário, caso seja necessário.

Durante a permanência na instituição, as gestantes exercem atividades com atuação na lavanderia, na cozinha, no lactário, na loja de roupa infantil, no carrinho de lanche, no laboratório, na secretaria, entre outros. Para a distribuição de atividades entre as mulheres, são consideradas suas habilidades. As atividades nos diversos setores são desenvolvidas de segunda à sexta-feira, das $8 \mathrm{~h}$ às $15 \mathrm{~h}$, com intervalo para lanche após o desjejum e também para o almoço. Antes de iniciarem as atividades, as mulheres recebem treinamento específico nos diversos setores. Para incentivar a permanência no abrigo, são oferecidos pontos semanais, baseados no comportamento social entre as mulheres, participação da consulta do pré-natal, participação das atividades diárias, objetivando o recebimento do enxoval completo para o bebê, que é retirado no bazar mantido pelas voluntárias, no próprio Alojamento Social.

O Amparo Maternal, há 36 anos mantém um grupo de voluntárias que trabalham no bazar, como também na organização das doações e na capacitação profissional. Preocupada com a oportunidade de trabalho, uma equipe de profissionais oferece às mulheres capacitação profissional em corte e costura, computação, culinária, serviço doméstico, overloque, bordado, tricô, alfabetização, contribuindo, assim, com maiores oportunidades quando voltarem ao convívio social anterior. Tais 
atividades são realizadas logo após o lanche da tarde, no horário das 15 h e 30 min às 18h, de segunda a sexta-feira. Assim, todo período diurno é ocupado com atividades não havendo tempo ocioso.

Além das atividades para a capacitação profissional as voluntárias trabalham no bazar, na organização e na venda de mercadorias doadas por pessoas físicas como também por empresas. Todo dinheiro arrecadado é revertido para o hospital.

Entre outras atividades realizadas pelas voluntárias encontra-se a orientação quanto aos cuidados com o recém-nascido.

O primeiro contato da mulher grávida abrigada no Alojamento Social do Amparo com a assistência à saúde, geralmente, ocorre no pré-natal, sendo então, acompanhadas até o término da gestação. Após o nascimento, mãe e filho permanecem internados no alojamento conjunto da maternidade, por aproximadamente, 24 horas para aquelas que tiveram parto normal e 48 horas aos casos de parto operatório. A sua alta da maternidade favorece o retorno ao Alojamento Social, onde permanecem até surgir possibilidade de retorno para o local de origem ou para aquele que se viabilizar.

Neste período, a mulher assume integralmente o cuidado de seu filho dandolhe suporte emocional e nutricional. São estimuladas ao aleitamento materno, higiene e conforto. Não só a interação mãe e filho estão presentes nesta fase, pois as puérperas do alojamento social interagem entre si trocando experiências a respeito da saúde de seus filhos e delas próprias, como também das expectativas futuras de cada uma.

O tempo de permanência das mulheres na instituição, após o parto, depende de cada situação a ser avaliada pela assistente social. Mas em situação de extrema 
necessidade social, é possível que a permanência na instituição dure até um ano ou mais.

\subsection{SUJEITOS DA PESQUISA}

Os sujeitos deste estudo são mulheres que vivenciaram o processo gravídico, de forma singular, como moradoras no Alojamento Social do Amparo Maternal.

No estudo, foram incluídas as mulheres que estavam vivendo a experiência do processo gravídico, morando na instituição, no mínimo, há um mês. Julguei este tempo suficiente para que as mulheres tivessem vivenciado a situação e interagido socialmente entre elas e todos aqueles que fazem parte desse grupo social.

Para selecionar os sujeitos do estudo, observei as mulheres nas atividades que desenvolvem na lavanderia, na copa, nas aulas de costura, bijuteria, na alfabetização, no período da tarde, geralmente, às quartas-feiras. Fiz observações, ainda, às terçasfeiras de manhã, no grupo de gestantes coordenado pela psicóloga e, aos sábados, no horário em que recebem visitas. $\mathrm{O}$ ambiente de realização da atenção pré-natal também foi utilizado para seleção das mulheres.

A observação permitiu identificar quais gestantes estavam vivendo na instituição, pelo menos, há um mês e iniciar uma relação a fim de facilitar o convite para participar na pesquisa. Permitiu ainda identificar aquelas que apresentavam condições satisfatórias na comunicação. Em uma situação particular uma gestante ofereceu-se para ser entrevistada, pois ao ficar sabendo que sua companheira de quarto havia sido convidada, manifestou o desejo de contribuir com o estudo. 
O número de mulheres não foi estabelecido a priori, mas definido em função da qualidade do conteúdo que respondia a meus objetivos. Assim, as colaboradoras do estudo foram dez mulheres, entre gestantes e puérperas.

\subsection{ASPECTOS ÉTICOS}

A realização do estudo foi autorizada pela Diretoria da Instituição, após o encaminhamento do projeto de pesquisa à Presidente Executiva do Amparo (Anexo A). O projeto foi aprovado pelo Comitê de Ética em Pesquisa da Escola de Enfermagem da Universidade de São Paulo, como consta no processo $\mathrm{n}^{\mathrm{o}}$ 561/2006/CEP-EEUSP (Anexo B).

A inclusão das mulheres na pesquisa ocorreu após a assinatura do Termo de Consentimento Livre e Esclarecido (Anexo C), conforme previsto pela Resolução CNS 196/96, que dá as diretrizes e normas regimentais de pesquisa, envolvendo seres humanos (Brasil, 1996).

Em um segundo momento, foi solicitada à direção do Amparo Maternal a liberação para fotografar outras mulheres em atividades no processo gravídico e também, na execução de outras atividades.

\subsection{COLETA DOS DEPOIMENTOS}

No método fenomenológico, segundo Moreira (2004), as principais estratégias de coleta de dados são:

Entrevista: os participantes descrevem verbalmente suas experiências. 
$\checkmark$ Descrição de experiência escrita pelo próprio participante.

$\checkmark$ Relatos autobiográficos em forma escrita ou oral.

$\checkmark$ Observação participante: o pesquisador parte das observações do comportamento verbal e não verbal dos participantes.

A entrevista não diretiva permite obter dos sujeitos entrevistados, suas idéias, opiniões e maneira de sentir em nível mais aprofundado (Carvalho, 1991).

$\mathrm{Na}$ entrevista semi-estruturada, o entrevistador faz algumas questões em uma ordem predeterminada, porém com liberdade; outras questões podem ser formuladas conforme a necessidade de entendimento para o pesquisador (Moreira, 2002).

A entrevista é uma das técnicas de coleta de dados, ou seja, uma ferramenta imprescindível para buscar o comportamento dos sujeitos em relação a seus sentimentos, crenças, valores e permite, sobretudo, que se obtenham dados sobre o seu passado recente e longínquo, de maneira clara (Rosa, Arnoldi, 2006).

O entrevistador deverá transmitir atitudes de confiabilidade, pois as informações dadas pelos sujeitos podem ser inteiramente afetadas quando a natureza da relação com o entrevistado não for adequada (Minayo, 1998).

Esta técnica de coleta de dados proporcionou a obtenção do significado subjetivo da ação humana pelos sujeitos deste estudo.

Para a obtenção dos depoimentos referentes à experiência vivida por mulheres no processo gravídico, sendo moradoras de uma instituição social e de saúde, realizei entrevistas, seguindo roteiro com questões abertas. Para tal, as questões norteadoras foram:

- Qual era sua expectativa ao vir para cá?

- Como é viver aqui neste período, estando grávida? 
- Como está sendo o cuidado à saúde que você recebe? Foi como você esperava?

- O que você pretende fazer quando for embora?

Com a intenção de retratar as mulheres colaboradoras deste estudo e compreender o contexto de vida de cada uma delas anteriormente à condição de moradora do Amparo Maternal, iniciei a entrevista realizando a questão: Como era o seu dia-a-dia antes de vir para cá?

A coleta de dados por meio de entrevistas iniciou-se no segundo semestre de 2006. As entrevistas foram realizadas na instituição, geralmente, no período da tarde e aos sábados, em um local que garantisse a privacidade das mulheres e tranqüilidade, para que a gravação não tivesse problemas técnicos.

Embora as mulheres já tivessem sido orientadas no momento da seleção, expliquei novamente os objetivos da pesquisa, propondo-me a outros esclarecimentos, caso fosse preciso. Solicitei, então, consentimento para a gravação dos depoimentos e sua utilização para a pesquisa e publicações científicas e, também, a assinatura do Termo de Consentimento Livre e Esclarecido (Anexo C).

As entrevistas foram gravadas em fita cassete, pois fornecem uma expressão mais acurada comparada com outros métodos de registros dos dados (Yin, 2001).

Procurei deixar o ambiente descontraído e propício, como também estabelecer uma relação empática com as mulheres. Tomei o cuidado de ficar atenta durante a entrevista, deixando de lado os preconceitos, observando as reações emocionais apresentadas por elas, que de certa forma subsidiam a compreensão do significado que aquele depoimento exercia na mulher que estava vivendo a situação. 
Em várias ocasiões, no decorrer das entrevistas, encontrei-me na situação de querer entender melhor a experiência vivida por elas, sendo assim, utilizei-me de estratégias para que as mulheres falassem mais sobre o assunto, porém tomando o cuidado de não influenciar nas respostas. Para isso, solicitava que falassem mais sobre aquilo que queria entender.

Os depoimentos foram transcritos na íntegra por mim, assim, evitando omissões e respeitando a integridade e a seqüência, como também a linguagem das mulheres, garantindo a fidedignidade dos dados. Inicialmente, as transcrições foram manuscritas e digitadas, logo em seguida para, posteriormente, serem lidas na íntegra. O fato de ter transcrito por duas vezes os discursos facilitou seu entendimento.

$\mathrm{Na}$ transcrição das entrevistas, com a finalidade de manter em sigilo as colaboradoras do estudo, elas foram identificadas pela composição da letra D (depoimento) e do algarismo romano na ordem de realização das entrevistas. Os depoimentos na íntegra constam no (Anexo D).

Com a finalidade de avaliar a qualidade e a transparência das questões para obtenção dos depoimentos, entrevistei uma gestante que participava do grupo com a psicóloga. Não houve dificuldade de entendimento das questões, porém foi prudente complementar uma das questões, objetivando maior clareza para o entendimento das mulheres. Sendo assim, a questão: Como é viver aqui neste período? Foi modificada para Como é viver aqui neste período, estando grávida? 


\subsection{PASSOS DA ANÁLISE}

Para a compreensão do significado da ação vivenciada pelas mulheres moradoras em uma instituição social e de saúde organizei e categorizei o material obtido percorrendo alguns caminhos. Utilizei-me dos apontados por Giorgi (1985) Fini (1994), e os modelos de Merighi (2000), Fustinoni (2000) e Campoy (2003) adequados a este estudo.

Após entrevistar as mulheres e transcrever na íntegra seus depoimentos, realizei leituras minuciosas do material bruto objetivando, em primeiro lugar, apreender o sentido geral das experiências vividas por elas. Ressalto aqui que, após ter realizado e transcrito cinco entrevistas com as gestantes, identifiquei as unidades de significado ou de sentido desses depoimentos. Notei que não havia experiências sobre todas as etapas do ciclo gravídico vividas no Amparo Maternal, o que me levou a selecionar e entrevistar algumas puérperas.

Moreira (2002) alerta que o pesquisador precisa sentir-se à vontade com o texto e ler quantas vezes for necessário, para obter uma base do conteúdo e poder passar para uma próxima etapa.

Nas leituras subseqüentes dos discursos, identifiquei os trechos das falas que tinham maior significado e que se relacionavam com os objetivos do estudo, ou seja, parte da descrição que é considerada essencial do fenômeno, na perspectiva do pesquisador, seja ela sociológica ou psicológica. Sendo assim, agrupei os aspectos em comum, isto é, as convergências ou invariantes, que possibilitaram o emergir das categorias concretas do vivido de mulheres que vivenciaram o processo gravídico, morando no Amparo Maternal, instituição social e de saúde. 
Após várias leituras e reestruturação das categorias iniciais, o agrupamento dos trechos identificados - unidades de sentido - resultou em várias subcategorias que emergiram para quatro categorias: Buscando soluções; o dia-a-dia no Alojamento Social do Amparo; o cuidado à saúde no Amparo Maternal e retornando ao cotidiano com novos projetos.

Simultaneamente à construção das categorias, dediquei atenção aos motivos por que e aos motivos para das ações das mulheres. Para isso foi de suma importância não me afastar das questões norteadoras do estudo como também de minhas indagações iniciais.

Após a organização e categorização do material, obtive a tipologia do vivido. O tipo vivido é a reflexão da vivência do sentido comum que ocorre em um determinado contexto, no cotidiano do mundo social. A tipificação desempenha um papel importante na compreensão do outro e na intenção social (Schütz, 1974a).

Nos depoimentos de gestantes e puérperas moradoras de uma instituição social e de saúde, busquei suas experiências bem como o significado que elas atribuem às suas ações, a partir de quando passaram a viver no Alojamento Social do Amparo Maternal. Estive atenta, também, para compreender seus projetos de vida futura, para quando deixarem essa condição, retomando seu cotidiano. Busquei, então, chegar à essência do fenômeno. 
4 AS MULHERES MORADORAS DO AMPARO MATERNAL 


\section{AS MULHERES MORADORAS DO AMPARO MATERNAL}

A compreensão do outro depende de conhecer os motivos por que de seus atos, portanto, senti a necessidade de investigar um pouco a história de vida das mulheres antes de serem moradoras do Alojamento Social. Fundamentei-me em Schütz (1974b) e Wagner (1979), que consideram a forma de agir dos indivíduos determinada por suas experiências passadas. A idéia e a concretização de projetos futuros são determinadas por sua história de vida, por sua situação ou circunstância pessoal. As experiências passadas são categorias objetivas, nas quais o sujeito reflete os acontecimentos.

Embora a experiência de vida de cada mulher seja única, suas histórias apresentam características comuns como:

- dificuldade financeira causada pelo desemprego ou subemprego;

- convívio familiar conflituoso que, muitas vezes, gerava violência física e emocional;

- convívio familiar harmonioso proporcionando condições de estudo sem necessidade de trabalhar, mas que não pôde ser aproveitada pelas mulheres;

- uso de drogas ou convívio com usuário de drogas, também, gerando conflitos, pois os familiares não aceitavam seus parceiros; e

- gravidez não planejada, porém aceita em certas circunstâncias e em outras não. Ora é a própria mulher que a rejeita outras vezes é o companheiro que nega sua participação no evento. Os familiares também rejeitam a gravidez por sua ocorrência fora do casamento ou 
porque não aceitavam o pai da criança, pois o julgavam-no de mau caráter.

As mulheres, ao contarem suas experiências passadas, fizeram uma reflexão sobre estes acontecimentos. Sentem-se culpadas por não terem aproveitado a oportunidade de estudarem, de terem entrado no mundo das drogas, avaliam o relacionamento familiar, a relação com o companheiro e a gestação. Nota-se que ao voltarem para o passado, tornaram-se observadoras de seus próprios atos (Wagner, 1979).

A seguir, retrato as mulheres moradoras do Alojamento do Amparo Maternal, utilizando os seus depoimentos ao serem indagadas sobre como era o seu dia-a-dia, antes de vir para cá.

DI tem 23 anos de idade, é solteira e possui o ensino médio completo, quando realizei a entrevista estava com 28 semanas de gestação, morava na instituição há dois meses e descreveu assim seu cotidiano:

Às vezes, era bom, às vezes, era ruim né? Às vezes, eu estava em casa bem, tinha hora que estava apanhando. Às vezes, eu tinha o que comer, às vezes, eu não tinha o que comer, entendeu? Mesmo passando por o que eu passei, mesmo ele falando que ia me matar. Eu não consegui tirar ele da minha cabeça, ainda, entendeu? ... Ele já arrumou outra, já está com outra, então! ... A semana passada, ele veio aqui. Eu gosto dele, mas se fosse para voltar com ele, não sei se voltaria não ... Antes de vir para cá, eu não trabalhava, só ficava em casa mesmo. Eu tinha uma filha, tinha não, eu tenho. Mas minha mãe sumiu com a minha filha, por um relacionamento que eu tive. Minha mãe não gostava desta pessoa. Não queria que eu fosse morar com esta pessoa, tinha medo que eu levasse minha filha. Então, o que 
minha mãe fez, pegou minha filha, e sumiu com a minha filha. Faz um ano que eu não vejo a minha mãe e nem minha filha, entendeu? Foi aí que conheci o pai deste, me envolvi. Quando eu morava com a minha mãe, eu não trabalhava, só estudava, quando fui morar com ele eu acabei de estudar e estava tentando entrar na faculdade. Mas como a minha mãe sumiu com a minha filha, resolvi procurar a minha filha. Fui para Minas, procurei em tudo que era lugar, mas não achei. Então, não tenho nem idéia aonde ela está. São Paulo é grande, ela está em São Paulo, mas, aonde? (DI)

DII tem 27 anos é casada com separação de corpos e possui o ensino fundamental incompleto. Quando a entrevistei, estava na $36^{\mathbf{a}}$ semana da gestação e morava na instituição, há seis meses.

Bom, minha vida antes de vir para cá era, ... Ah! Eu morava com a minha sogra, cuidava de meus dois filho, né? Era muito difícil, o meu marido estava preso, ficou paraplégico (tomou um tiro), e acabei ficando na casa dela com os dois filhos, mas era muita briga (pausa). ... eu fiquei grávida, escondi dois meses. Minha sogra descobriu e me pôs para fora, foi onde me indicaram aqui. Me pôs para fora em ambas as partes: primeiro, eu fiz uma besteira (ri). Aconteceu lá, fui visitar o meu marido e engravidei de outro lá.... E os meus filho ficou com ela, com minha sogra e minha cunhada, e estou aqui há seis meses, ... Ela me mandou embora, porque não é do meu marido. Eu engravidei de uma pessoa, porque o meu marido estava paraplégico. Então, ele não faz mais nada ... como não é dele ... ele não faz mais nada. E o pai do nenê, como era uma pessoa que também vivia nas droga, acabou não sei que diacho, acabaram matando ele também. A família dele queria o neném, mas toda a família mexe com droga. Então, eu tenho medo, não deixo. No caso se não tenho condições de cuidar do nenê, eu deixo ele aqui ... Então, já que o pai faleceu! O 
pai também não era (pausa). Eu prefiro o pai dos meus dois filhos, do que deste aqui ... Eu fui lá esta semana, fui levar os meus filhos para ele vê. O meu filho mais velho tem cinco anos e o outro quatro; então, eles precisam ver o pai, ... Nós decidimos ficar na maior amizade, pelo menos, por causa das crianças ... Já a minha sogra não, ela é osso duro de roer ... Mas é o seguinte, a minha cunhada me apóia, ela não me discrimina, ficou chateada, mas quer que eu volte para cuidar dos meninos ... O mais velho fica mexendo na barriga e perguntando. Eu não sei como explicar para eles, estou totalmente perdida. O pai fala que, quando eles crescerem, eles vão saber o que eu fiz, mas isto não tem como esconder, mas filho não perde amor da mãe! ... Ele pergunta o que eu vou fazer com a criança, perguntou quem é o pai, eu falei. Contei o que aconteceu. ... Ninguém sabe sobre isto, só uma assistente social. ... Se eu tivesse, pelo menos um lugar. Porque ir para a minha sogra eu não vou. A minha mãe não vive uma vida muito boa com o meu pai, ele não aceita. Ele só aceita eu sozinha sem nenhuma criança. ... Se eu não tivesse engravidado ninguém ia saber. Minha sogra ficou magoada porque eu engravidei. Só que quando ele resolvia sair, ele saia, ele saiu com uma amiga minha e não me respeitou. Eu não estou pagando com a mesma moeda. A minha sogra sabia e escondeu de mim. (DII)

DIII tem 17 anos de idade, é solteira com companheiro, possui o ensino médio completo. Quando a entrevistei estava no nono dia pós-parto e morava na instituição por três meses.

Antes de vir para cá, eu saía demais, todo o final de semana estava saindo. Ficava direto fora de casa ... Mas aí uma vez, a última vez, eu descobri que estava grávida. Fiz exame, a minha mãe estava com raiva de mim, e como a minha tia ganhou os três filhos dela aqui. Aí minha tia me trouxe para cá. A minha mãe estava 
com raiva e me mandou para cá. Antes eu ia na igreja, era evangélica. Aí depois eu quis sair, ia para baile, mas a minha mãe não deixava. Aí eu saía do mesmo jeito, saía dormia fora, bebia demais, usava droga. Mas graças a Deus! Não fiquei dependente, depois a minha mãe descobriu. Eu sempre tive um bom relacionamento com a minha família. Mas eles começaram a se distanciar. Contei para a minha mãe a verdade e ela me levou no Caps de Pirituba, para fazer o tratamento de droga, fiquei dois dias. Aí descobri que estava grávida. Aí minha tia me trouxe para cá ... fiquei vinte dias só saindo. Eu não voltava para casa, eu pedia para o meu tio me buscar, fiz isso três vezes. Aí minha mãe foi me buscar, eu estava na casa de uma colega, era tipo uma favela. ... Eu tenho um irmão de dois anos, é como se ele fosse meu filho, quando eu trabalhava comprava coisa para ele. Eu sou muito apegada a ele, e ele também, às vezes, até demais. Às vezes, eu tinha vontade de voltar pelo meu irmão, mas tinha vergonha, porque ficava muito tempo fora. Meu pai é separado da minha mãe, eu não me dou bem com ele. Ele é alcoólatra e fica agressivo, bate na minha mãe. Quando ele bebia, ele vinha em cima de mim. Ele mora lá em Itaquera. Ele vinha, ficava uma semana e depois ia embora. Toda vez que ele bebe, ele desconta em mim. Ele me bateu grávida. Ele queria que eu tratasse como pai, e eu não trato como pai, ele fica bravo. Eu trabalhava, fui trabalhar com 14 anos, trabalhava na padaria, acordava às cinco e meia da manhã, eu era a que trabalhava mais e que ganhava menos. Trabalhava como babá. (DIII)

DIV tem 26 anos, é solteira com companheiro, possui o ensino médio completo. Quando entrevistei estava com 32 semanas de gestação e morava na instituição há quatro meses. 
Eu não me dava muito bem com os meus pais adotivos, eu acabei indo morar com ele (o pai da criança). Foi um pouco difícil, porque ele começou a entrar com as drogas, influência dos amigos, foi bem difícil ... A minha convivência na minha casa não era boa, sempre o problema era comigo porque sempre tinha um motivo para brigar ... com o meu irmão era mais calmo. Eu sempre tive de tudo, só estudava, mas eles jogavam na cara. Eu não ficava muito em casa, ia para a casa de algum amigo, na escola era tudo bem, tudo normal. Em casa, cada um pensa de um jeito, meio diferente de pensar. Então, acabava saindo conflitos. Os meus pais biológicos, eu queria conhecer ... O relacionamento com o meu irmão, não era muito bom. A gente não se fala muito não, era só o básico, também, só o necessário. O meu pai era mais aberto, mas, não totalmente. Eles não dão espaço para a gente poder conversar. Eles já são de idade, então, tudo para eles parece estar errado, pessoas bem antigas. Não tinha diálogo, então, eu conversava com a amiga, com parente também não, madrinha ... Eu tenho uma amiga que mora ao lado do prédio do meu pai, praticamente, nós crescemos juntos. Então, a gente conversa muito, sempre ela me dá força, ela vem me ver, me visitar. Atualmente, ela não está vindo, ela tem os compromissos dela. Mas ela me dá conselhos, ela já conhece os meus pais. Então, ela pode falar, dar conselhos. (DIV)

DV tem 22 anos, é solteira, possui o ensino fundamental incompleto. Quando entrevistei, estava com 38 semanas de gestação e morava na instituição há três meses.

Era bom, não trabalhava. Ficava em casa com minha filha, minha mãe nunca mandou eu ir trabalhar, tinha de tudo. A minha vida era assim, tudo que eu pedia para ela, ela me dava, ela sempre me ajudou ... Eu morava com o pai dela (primeira filha), aí eu engravidei, mas eu não gostava da mãe dele. Aí ele ficou comigo cinco 
meses, aí fui para casa e minha mãe ficou comigo. Eu conheci o pai dela (filho em gestação), ele é peruano ... eu conheci no centro da cidade. Aí começamos a namorar, aí engravidei dele, ..., e ele falou que não era dele. Aí a minha mãe ficou atrás dele, e ele falou para não ir atrás dele, se não ele ia fazer alguma coisa com a gente. Aí minha mãe me colocou para fora de casa e eu vim para o Amparo Maternal. A minha família não queria que eu ficasse com ele. ... A família falou para mim tirar a criança, deve tomar remédio. Aí eu falei que não ia tirar o neném. Vou ficar com o meu filho ... Aí o meu padrasto me colocou na rua e a minha mãe também ... Eu estava chorando na praça da Sé. Aí veio uma moça perguntou se eu estava passando mal. Eu falei tudo para ela, e ela me encaminhou para o Amparo. Eu antes estudava, ... comecei a faltar, abandonei a escola, comecei para a balada, saia na terça voltava só no domingo. Minha mãe ficava preocupada comigo, então, eu mesmo me prejudiquei. Quando conheci ele (pai da criança), não queria mais ficar com a minha mãe e comecei a fumar cigarro. Eu andava com o pai da minha filha e comecei a fumar crack ... e minha mãe viu que eu estava muito estranha. Minha mãe disse: você não fumou cigarro! Fumou outra coisa. Aí minha prima disse nós usamo droga. Minha mãe me bateu e colocou para fora, fui para a casa de minha vó, e continuei usando droga. Eles queriam me internar, eu disse não, não sou viciada! O pai da criança foi atrás de mim e falou pra trabalhar com ele. Ele roubava e colocava a mercadoria no carro e nós vendia celular roubado. Mas a polícia viu ele roubando e prenderam ele. Aí aparecen a mulher dele e perguntou se en estava com o marido dela, eu disse que não! (DV) 
DVI tem 20 anos, é solteira, possui o ensino fundamental incompleto. Quando entrevistei, estava com 40 semanas de gestação e morava na instituição, há quatro meses.

Não era muito bom porque eu usava drogas. Na época, até os seis meses, usei drogas, vivia na rua, usando drogas. Estava na clínica para não usar drogas, aí eu fugi e vim para cá. Agora estou melhor, não estou usando droga, coloquei na minha cabeça que eu quero mudar mesmo. Eu saí de casa nova, eu tinha 15 anos. Aí a minha mãe falou ou você vai para a igreja Testemunho de Jeová, ou para casa. Aí eu vim para a rua, ficava na rua usava droga, fiquei três anos na Bahia, tive um filho. Vim para São Paulo, comecei a usar o crack e engravidei de minha outra filha. Depois um ano e pouco, engravidei de novo na rua de um cara, mataram o cara, eu perdi o neném, e engravidei deste. A minha família perdeu a confiança. Acredito, agora que eles estão vendo que eu estou querendo mudar, estão me dando voto de confiança. (DVI)

DVII tem 36 anos, é solteira, possui o ensino fundamental incompleto. Quando a entrevistei, estava com 17 dias de pós-parto e morava na instituição há dois meses.

Bom, o meu dia-a-dia eu trabalhava em uma casa de família. Tomava conta da casa, eu não era de sair não. Era normal, eu morava no serviço, eu fazia tudo, depois que eu fiquei grávida eu sai de lá. No final de semana, eu ia ver o meu filho que mora com uma prima. Eu não tenho marido, aqui em São Paulo, eu não tenho família não, porque meu pai mora na Bahia. Tem esta prima minha que é prima de meu pai que é aqui de São Paulo. Os meus irmãos também moram na Bahia, eu fui criada pela minha vó. Quando ela morreu, eu fui morar com a minha tia, e depois ela mandou eu morar com o meu pai, quando eu tinha 14 anos. Aí eu fiquei um tempo lá na Bahia, 
quando eu tinha 19 anos, eu vim para cá, estou até agora aqui, só trabalhando na casa de família. E, nesta, eu conheci o pai da minha filha, ele trabalha perto da loja de minha patroa. Eu conheci ele lá, comecei sair com ele e aí engravidei. Aí eu pensei em abortar, aí ele foi contra. Aí eu acabei aceitando, né? Aí eu tipo assim, eu estava trabalhando, aí minha patroa estava em situação financeira ruim e eu não pude ficar lá. Não podia me pagar. Ela nem sabia que eu estava grávida porque eu escondi. Aí eu falei para ela e ela disse, eu não vou ficar contigo. Aí eu me informei na igreja e eles falaram que tinha esta instituição que ajudam mulheres grávidas, aí eu vim para cá, eu estava com sete meses de gestação. (DVII)

DVIII tem 18 anos, é solteira, possui o ensino fundamental incompleto. Quando a entrevistei, estava com 30 dias de pós-parto e morava na instituição há três meses.

Eu trabalhava, estudava. Era amigada, aí me separei e fui morar com a minha avó. Aí fiquei sabendo que estava grávida, voltei para o meu marido. Aí a gente brigamo e a minha madrasta não me aceitou em casa. A vida dela é só ela o meu pai e meu irmão. Aí eu tive que vir para cá. O pai do meu filho não sabe que ele nasceu, não ficou sabendo que estava grávida. A relação com a minha família não era muito boa, eu era a ovelha negra da família, porque saia para as baladas e só voltava aos domingos. Estudava à noite e todo dia era a mesma coisa. A minha família achava que tudo que eu fazia, era errado. (DVIII)

DIX tem 28 anos, é solteira, possui o ensino fundamental completo. Estava com 30 dias de pós-parto e morava na instituição, há dois meses quando forneceu o depoimento. 
Eu morava com o pai da minha filha há dois anos. Engravidei e com cinco meses começaram as brigas. Começou brigar muito e nossa vida ficou difícil, ele mudou ficou agressivo. Minha família mora longe no interior do Nordeste. O meu filho de 12 anos ficou com a minha mãe. O pai deste filho chegou me agrediu. Aí eu descobri aqui com uma amiga e resolvi ver como é. (DIX)

DX tem 27 anos, é solteira, possui o ensino fundamental incompleto. Quando entrevistei estava com 30 dias de pós-parto e morando na instituição há dois meses.

Minha vida antes era turbulenta, eu não sabia o que eu queria, confusa. Quando eu fiquei grávida eu não aceitei, porque não foi planejada. Perdi emprego, curso. Era uma pessoa depressiva sem saber o que eu queria, em qualquer lugar que eu ficasse, poderia ser um palácio ou uma roça. Eu queria me esconder de todo mundo, ficar sozinha eu e meu filho. O Amparo Maternal me deu assim uma certeza psicológica, porque abalou o meu psicológico, tive muitas mudanças, fiquei muito inchada, acho que eu fiquei uma pessoa estranha, esquisita, antes de eu vir para cá estava bastante complicado. Posso dizer morta espiritualmente. O Amparo me trouxe uma alegria profunda, uma vontade de viver. Eu mal me olhava no espelho e, hoje, eu me encontrei, me sinto resolvida, concentrada. Quando eu fiquei grávida, eu não sabia se ia ficar com os meus pais, com o meu namorado, se ia procurar minha antiga patroa. Fiquei com vergonha de voltar para a minha família, porque eu era independente. Eu já morava fora há sete anos, fiquei com vergonha de procurar o meu pai e minha mãe. Eu queria enfrentar sozinha, mas não estava em condições, primeiro estava desempregada. Fiquei na casa de amigos, mas eu sentia que era um peso a mais. Por eu não estar trabalhando afetou o meu psicológico, eu joguei dinheiro fora, eu gastava muito. (DX) 
5 ANÁLISE COMPREENSIVA 


\section{ANÁLISE COMPREENSIVA}

Este capítulo contém o esquema das categorias concretas do vivido, a análise destas categorias e a construção do tipo vivido de mulheres que vivenciaram o processo gravídico, morando no Amparo Maternal, instituição social e de saúde.

\subsection{ESQUEMA DAS CATEGORIAS CONCRETAS DO VIVIDO}

- Em busca de acolhimento

- Querendo mudança na condição de vida

- Convivendo positivamente com a experiência do outro

- Sentindo-se em casa

- Convivendo negativamente com a experiência do outro

- Sentindo falta dos familiares

- Sentindo solidão

- Sentindo-se privada de liberdade

- Percebendo receber apoio

- Percebendo a possibilidade de aprendizado

- Vivenciando positivamente a atenção à saúde

- O cuidado à saúde durante a gravidez superando expectativas

- Qualificando a atenção recebida no parto

- Criticando o cuidado à saúde oferecido

Buscando soluções

O dia-a-dia no Alojamento Social do Amparo

O cuidado à saúde no Amparo Maternal
Mulheres que vivenciam

o processo gravídico, morando em uma Instituição social e de saúde 


\subsection{CATEgORIAS CONCRETAS DO VIVIDO}

\subsubsection{Categoria 1: Buscando soluções}

As experiências vividas por mulheres moradoras temporárias em uma instituição social e de saúde, anteriormente a essa condição, fazem parte de sua situação biográfica. Cada mulher ocupa seu espaço de maneira específica, possui uma bagagem de conhecimento disponível adquirida ao longo de sua vida. Desde a infância o indivíduo armazena uma grande quantidade de conhecimento, que é utilizado como técnica para compreender aspectos de suas experiências. A bagagem de conhecimento é adquirida por intermédio dos familiares, mestres, que vivem o mesmo tempo e espaço, como também por seus predecessores. Este conhecimento e experiência do sujeito servirão como base de suas ações futuras (Schütz, 1974b).

O estoque de conhecimento que o homem tem à mão, serve como código de interpretação de suas experiências passadas e presentes, como também determina sua antecipação das coisas futuras que virão. O estoque de conhecimento é constituído de e por atividades anteriores as nossas vivências. A experiência em curso pode ser identificada com uma anterior que se repete ou com uma experiência anterior igual, mas modificada ou então a experiência em curso aparece como estranha (Wagner, 1979).

Na vida das mulheres moradoras temporárias na instituição social e de saúde, cenário do estudo, independente de suas experiências anteriores serem boas ou ruins, sob nosso olhar, a gravidez simplesmente aconteceu, porém, em contexto de relação de significado para elas. Diante do conhecimento adquirido no decorrer da vida, cada uma delas posicionou-se para uma ação futura. 
A Fenomenologia Social permitiu desvelar os motivos para que as impulsionaram na busca de soluções para os problemas ocasionados pela ocorrência da gravidez. Diante de poucas possibilidades de continuarem no mesmo ambiente social após a descoberta de que estavam grávidas, as mulheres buscaram uma maneira para solucionarem o problema e para isso empreenderam ações que beneficiassem a elas e a seus filhos. As subcategorias que compõem a categoria "buscando soluções," estão repletas de motivos para, como pode ser visto nos discursos.

Diante da atitude natural, as mulheres enfrentaram esta situação lançando mão da bagagem de conhecimento adquirido no decorrer de suas vidas. Na busca de soluções a seus problemas, depositaram no Amparo Maternal esperança de serem acolhidas, mesmo para aquelas que foram orientadas a procurarem a instituição. A vivência da gravidez associada à perda do seu convívio social habitual e da moradia gerou nas mulheres várias preocupações, destacando-se como recuperar abrigo, deixar de usar drogas e ter nutrição adequada para uma gravidez mais tranqüila. Frente a estas preocupações as mulheres demonstram vínculo afetivo com seus filhos. Ficar na rua grávida impede que as mulheres obtenham qualquer tipo de assistência à saúde, comprometendo o equilíbrio biopsicossocial necessário para que a gravidez evolua normalmente.

Buscaram também o Amparo com a intenção de mudança de vida que, de certa forma, estava sendo projetada por elas.

Ir viver no Alojamento Social serviu de incentivo para mudança de postura de vida, tanto às mulheres que faziam uso de drogas como àquelas que permaneciam fora de casa por muito tempo, quer por lazer ou fuga. $\mathrm{O}$ fato de estarem submetidas às normas e regras possibilitou, deixarem de usar drogas lícitas e ilícitas 
temporariamente, como também não permanecerem na rua durante a gravidez garantindo, assim, uma vida melhor nessa condição.

É evidente que deixar o uso das drogas, requer ações sociais e de saúde mais efetivas, porém, ao tomarem conhecimento dos efeitos nocivos à saúde, as mulheres acreditam que sua permanência na instituição facilitará a não continuidade do vício.

\section{Subcategoria: Em busca de acolhimento}

A minha prima já cuida do meu filho, então ela não queria que eu fosse para lá (na casa da prima). A casa dela era pequena, o marido dela sustenta ela. Aí, eu vim, ... (DVII)

Eu estava morando com o pai desse aqui, ele me agrediu, né? Fui parar no hospital ... Ele falou para eu ir embora, ele tinha arrumado outra. Ia colocar outra dentro de casa, e que era para eu sair de dentro de casa, ... . Sabe, quando você sai de casa sem rumo? Eu saí sem rumo. Aí uma mulher me encontrou chorando na rua, perguntou o que aconteceu, eu falei. Aí ela me falou daqui. Eu nem sabia que existia este lugar, ...

Ah, antes de vir para cá, eu achava que era até bom para mim! Porque aqui dá a morada, se não tiver condições de ficar com o bebê também pode deixar o neném. Eu fiquei assim, não fiquei muito feliz de vir para cá,...vou tentar, não posso ficar na rua... (DII)

Atingir aos meus objetivos, o objetivo que eu tinha era vir para cá, era de não ficar na rua, ficar por ai andando grávida, né? Então, eu vim pedir ajuda na igreja e 
eles me indicaram para cá. Tudo para mim não ficar na rua, né? Tudo para eu ter um lugar por enquanto, ... (DIV)

... descobri aqui com uma amiga e resolvi ver como é. Eu achei que aqui era o lugar para ter o meu filho ... queria ter minha alimentação, tranqüilidade... (DIX)

Eu espero ter uma gestação boa, ... (DVIII)

... a minha expectativa é que ia me ajudar, mas por tudo que estava passando minha última opção era aqui. Mesmo que falasse positivo ou negativo. (DX)

Quando eu falei para a mulher que eu estava mal, ela falou do Amparo, se eu queria ir para lá, fica um monte de mulheres grávidas. Aí ela me colocou no carro, falou que aqui era bom, tinha maternidade. Eles davam o enxoval. No começo, eu fiquei chorando, porque nunca tinha passado por isso ... (DV)

\section{Subcategoria: Querendo mudança na condição de vida}

Minha expectativa era de mudar, né? Aqui têm as regras, não ia poder beber, não ter contato com as drogas, não poderia sair, sabia que eu não ia pode fazer toda as coisa. (DIII)

Bom, a expectativa de vim para cá é de ter uma vida diferente de vida, melhor, e de parar de usar drogas. Se eu continuasse com esta vida que eu estava, eu ia morrer e matar o meu filho. (DVI) 


\subsubsection{Categoria 2: O dia-a-dia no Alojamento Social do Amparo}

No mundo da vida diária, o homem não vive de forma alguma em um mundo privado, ele vive, desde o início, em um mundo intersubjetivo, compartilhado com os seus semelhantes, é um mundo comum a todos (Wagner, 1979).

Nessa categoria, "o dia-a-dia no Alojamento do Amparo Social", relembro duas de minhas indagações iniciais: qual é o sentido que as mulheres atribuem às suas vidas diante desta experiência neste contexto temporário? Como vivenciam a maternidade neste particular cenário institucional? Isto porque o foco deste estudo está centrado nestas questões.

As mulheres moradoras no Alojamento Social estão unidas e relacionam-se em um ambiente em comum. Percebem umas as outras e estabelecem uma relação social. Esta percepção só é possível quando compartilham experiências em comum.

As mulheres viveram suas experiências no processo gravídico juntamente com os outros de forma direta. A relação com o outro se fez no mesmo tempo e espaço, enfrentaram problemas e posicionaram-se diante deles. Neste convívio, perceberam as diferenças sociais e tiveram como resposta desta percepção a aceitação ou não das diferenças. O mundo natural sendo comum a todos nós, é o mundo das experiências, no qual as pessoas relacionam-se seu cotidiano, travando, assim, uma relação social (Schütz, 1974b).

Nesta relação social, as mulheres não só perceberam as diferenças entre os seus semelhantes como procuraram aprender com estas diferenças, respeitando a opinião do outro mesmo na diversidade. Compreenderam que cada mulher tem e mostra a sua história que é compartilhada naquela situação em comum entre elas. 
Vivenciaram juntas algumas situações semelhantes, como a falta dos familiares, a solidão, a privação da liberdade, a percepção do apoio durante a gestação e a possibilidade de aprendizagem. Nesta situação perceberam que o seu semelhante faz parte de seu mundo de experiência, mesmo nas relações não favoráveis.

Reconheço a situação vivida pelas mulheres nesse contexto, como sendo de ganhos e perdas, pois elas sentiram-se privadas da liberdade social, mas têm consciência do apoio que receberam durante a gestação e da possibilidade de aprendizado.

A situação face a face entre as mulheres moradoras no Amparo Maternal favoreceu uma relação nas quais suas ações foram realizadas consciente e claramente, porém nem tudo foi explicitado. Pode ser percebida pelas mulheres na relação social, diante dos gestos, olhares, entonação de voz, possibilitando, assim, o conhecimento consciente que a mulher tem do outro.

Bello (2004), estudiosa da fenomenologia social, comenta a situação empática entre os homens nada mais é do que o reconhecimento que se tem do outro. Eu reconheço o outro e o outro me reconhece, independente de ser uma relação de simpatia ou antipatia.

\section{Subcategoria: Convivendo positivamente com a experiência do outro}

A gente aprende a conviver com pessoas diferentes da gente. ... você aprende ter paciência, aprende conversar. (DI). 
Viver aqui você aprende muita coisa, porque você convive com muitas pessoas. ... Você acaba aprendendo a respeitar, cada um tem uma opinião, então, para mim foi bom. (DVII)

... então, várias histórias que a gente escuta. Cada uma com uma educação diferente sabe! Então, há quatro meses que estou aqui. Eu nuca tive inimizade com ninguém, sempre escutei, sempre. (DIV)

\section{Subcategoria: Sentindo-se em casa}

Gostaria de ressaltar que esta categoria está repleta de significado, pois no depoimento a mulher considerou que viver no Amparo é semelhante ao convívio familiar. Recebe carinho como se estivesse no colo da mãe e, também, ocorrem divergências com os seus semelhantes como em seu lar. No entanto, o que fica explicito, é o ambiente acolhedor que encontrou no Amparo, que se compara ao de um lar.

Aqui é como eu estivesse em casa, com um monte de irmãos, cada um com uma natureza, cada uma tem uma religião, cada um vê a vida com um sentido, cada um com um exemplo de vida. Depois tudo passa, a rivalidade passa depois que tem o filho ... Na calada da noite, aquele horário que você está com a sua mãe, aqui a gente parece que está em casa, mas só vê gente barriguda. (DX) 
Subcategoria: Convivendo negativamente com a experiência do outro

Podemos perceber as dificuldades para o convívio social entre as mulheres que vivem o processo gravídico morando no Alojamento do Amparo. As diferenças de comportamento entre as pessoas são apontadas por elas como geradoras de conflitos que surgem das conversas que trocam entre si. Mesmo experienciando esse convívio conflituoso, não responsabilizam o Amparo Maternal, mas, a relação entre as pessoas.

É bom, fora as conversas, as fofocas, eu gosto. Têm meninas que ficam falando da vida do outro, em vez de se preocupar com sua própria vida. ... Eu não gosto de fofoca e não tenho paciência, também. ... Têm meninas que querem ser mais que as outras ... tem muita fofoquinha ... (DI)

As meninas parece tudo louca ... mas a convivência, tem muita exigência ... O lugar não é ruim, mas a convivência, as meninas vão embora, que você já conhecia, ai você fica mais triste, às vezes, eu desconto na criança. (DII)

Está sendo bom e está sendo ruim, porque as meninas, às vezes, arrumam encrenca, fofoca ... (DVI)

É difícil, porque tem muita menina! Aí é difícil conviver com pessoas diferentes. (DVIII)

\section{Subcategoria: Sentindo falta dos familiares}

Independente das mulheres terem ou não boas relações com os seus familiares antes de morarem no Alojamento Social, sentem falta da família e têm a oportunidade de refletirem a respeito da relação social que mantinham com seus familiares. 
Culpam-se por algumas atitudes cometidas e que levaram ao arrependimento. É notória a importância do convívio familiar às mulheres.

As mulheres têm na memória as relações face a face que estabeleciam com os seus familiares, lembram-se das experiências diretas com eles e por estarem no Alojamento Social esta relação passa a ser retrospectiva. Mesmo depois da situação face a face já ser passado, ela ainda retém as suas características essenciais (Wagner, 1979).

Desde que eu cheguei aqui, é mágoa. Quando vou na minha mãe, fico nervosa, quando vejo os meus filho, e venho para cá, fico triste. A única coisa boa é a missa, que a gente reza e tenta acalmar a gente. E agora que estou no final da gravidez, aí sim que você está mais ansiosa. .... no dia da visita, a minha mãe não pode vir me visitar ... minha cunhada não pode trazer os meus filhos aqui. Então, você fica o quê? O primeiro dia que cheguei aqui era um inferno. ... chorava muito ... com saudades dos meninos ... não posso ficar na rua ... É muito duro quando vou visitar, saio $e$ deixo eles ... É bom, mas não tem a família, não está com ninguém. (DII)

... mas à noite sempre batia uma angústia, de tudo o que você fez ... ficava lembrando que fiz a minha mãe sofrer... chorava toda a noite, não por causa do lugar, mas porque eu lembrava o que tinha feito para a minha mãe. Ficava com saudades... (DIII)

Tinha dias que a gente ficava triste, porque estava longe de todos, todo mundo, da família, pai, do meu filho. (DVII)

Eu sinto muita saudades de minha família ... é difícil ficar aqui. (DVIII) Aqui dá saudades da família. (DIX) 
... está longe da família é muito dolorido, dá muita dor no coração, tremores. (DX).

\section{Subcategoria: Sentindo solidão}

A solidão acontece pela sensibilidade emocional própria da gestação, associada também à falta de liberdade, a não aceitação de precisar estar na instituição e a saudade de seus familiares. É interessante notar que, ao mesmo tempo, que as mulheres referem que permanecer no Amparo Maternal traz solidão, logo em seguida mencionam que não é pelo lugar, justificando que o mesmo é bom. Reconhecem, portanto, que a instituição traz benefícios, porém não impede o sentimento de solidão. Eu fiquei uma semana com depressão ... fiquei com medo dela voltar. ... Viver aqui com a gestação fica com depressão, neste lugar, ... porque você não tem direito de sair. Agora, viver aqui, eu vivo na solidão ... no fundo eu não queria estar aqui ... mas vai fazer o que, não tenho outro lugar para ir ... não é pelo lugar, o lugar é bom, mas tem coisa que eu não concordo ... esta criança vai nascer revoltada ... sou revoltada ... fico nervosa aqui dentro ... mas é muito bom por um lado; e assim estou até hoje aqui (DII)

Ficar aqui grávida não é bom, a gente fica muito carente ... (DVI)

\section{Subcategoria: Sentindo-se privada de liberdade}

As mulheres relatam a falta de liberdade que sentem por estarem morando na instituição, comparando-a com um presídio. Embora para viver fora da instituição 
também haja regras e as mulheres estão submetidas a elas, não percebem a necessidade de adoção de algumas rotinas para a própria organização e funcionamento da instituição. É natural, no entanto, as mulheres sentirem-se aprisionadas, pois a falsa sensação de liberdade da rua é comparada ao modo de viver no Alojamento do Amparo Maternal, como viver tendo muitas regras e atividades a serem cumpridas.

E tem mais, não pode dormir fora, perde a vaga também. Acho errado também, não é porque você dorme fora é que tem um lugar... e se você dormir em um hospital?...isto é pior que uma cadeia, não quero ficar aqui... Aqui a gente trabalha... e é impedido de sair...você tem direito a uma saída por semana... isto é contra a lei, impedir da pessoa sair... Aqui é o fim do mundo, eu só estou aqui por causa desta criança... (DII)

Viver aqui não é fácil para ninguém. A gente fica presa, parece um tipo presídio... Para mim, no começo não estava agüentando... (DV)

\section{Subcategoria: Percebendo receber apoio durante a gestação}

As mulheres perceberam receber apoio durante a gestação, que foi oferecido de forma direta e indireta, pois o fato de exercerem atividades diárias nos diversos setores da Maternidade faz com que a mulher volte-se só para o seu filho, desviando pensamentos que podem influenciar negativamente na gestação, como a própria solidão citada por elas. Receber ajuda dos profissionais em suas necessidades propiciou, para as mulheres, condição de vivenciar a gestação com mais tranqüilidade e maior sossego, favorecendo uma gestação mais saudável, sem muitos conflitos e incertezas, já que a gravidez é um período no qual a mulher se encontra mais 
vulnerável emocionalmente. O Amparo Maternal recebeu as mulheres que não tinham onde morar, possibilitando a sobrevivência de seus filhos e delas próprias. Forneceu alimentação e moradia, livrando-as de terem seus filhos na rua. Com os braços abertos o Amparo acolheu estas mulheres e possibilitou-lhes a elas perceberem o apoio oferecido durante a gestação. As mulheres abrigadas vêem a existência da instituição como positiva, uma luz no final do túnel.

No mundo da vida cotidiana encontramos barreiras, dificuldades e diante delas devemos agir para poder vencê-las ou nos conformarmos (Wagner, 1979). Neste sentido, ao procurarem resolver seus conflitos, estando grávidas e não tendo onde morar, as mulheres agiram, indo morar no Amparo Maternal temporariamente.

A expectativa das mulheres de serem acolhidas vem ao encontro da filosofia do Amparo Maternal que é "atender a todos que dela necessitem". Filosofia praticada e defendida por sua fundadora, Madre Marie Domineuc, no sentido de promoção da pessoa humana visando a sua reintegração social.

...de dia eu fazia amizade com as pessoas... De dia eu conversava com as outras me desabafava. Não tinha medo do parto, porque aqui todo mundo estava grávida, então não sente medo... Aqui ainda a gente trabalha, não tem tempo de parar...pensar outras coisas, só pensa em bebê, o dia todo em bebê... (DIII)

É bom porque você recebe comida, cobertor e banho. (DII)

Agora aqui está sossegado... Bom, viver aqui, ah, é muito bom! A gente tem ajuda... tudo que a gente precisa a gente tem. Têm os médicos do pré-natal, falam que está tudo bem com o bebê... O meu espírito está mais calmo do que se estivesse lá fora. Se eu estivesse lá fora eu ia passar uma gestação muito nervosa... mas não. Aqui a minha gestação está sendo bem calma, estou bem tranqüila em tudo. O meu 
relacionamento está tudo bem. Eu não tenho o que reclamar, eles não têm o que reclamar... Aqui é muito bom, tem ajuda de tudo, tudo que a gente precisa, a gente tem. (DIV)

...mas agora eu tenho que agradecer o Amparo, porque ele me recebeu de braços abertos. Tudo o que eu fiz aqui dentro, eles estavam do meu lado... Eu acho aqui bom, a gente não tem para onde ir ... Se não fosse eles o meu filho não estava mais vivo, se estivesse na rua não tinha o que comer e aqui no Amparo tem, não ia ter como tomar banho, me cobrir, como comer, a criança quando a mãe não come, ela não come, eu ia ter ela na rua. (DV)

Se eu continuasse com esta vida que eu estava, eu ia morrer e matar o meu filho. Aqui está sendo muito melhor... Está sendo bom, porque não falta nada para mim, para o meu filho... Quando está gestante é uma coisa, quando vira mãe fica mais fácil, separa das meninas, fica só em contato com o filho, não fica pensando em outra coisa. (DVI)

...mas sempre tem alguém para conversar. As assistentes sociais dão atenção, as irmãs, as pessoas do pré-natal, as enfermeiras dão toda atenção... tem sempre alguém para te guiar, sendo que lá fora não tem isso e aqui tem o cuidado, já que a gente está gestante. (DVII)

... é legal porque as assistentes sociais ajudam a gente. E elas ajudam a falar com o meu pai, porque eu achava que não tinha para onde ir. Aí o meu pai conversou com a madrasta e vai me assumir. (DVIII).

...eu não tenho o que falar. Eu gostei, tem as roupinhas, o médico, alimentação, remédio. A minha gravidez aqui foi tranqüila... não ficava ansiosa... 
aqui foi o melhor, aqui apareceu como uma luz. Sse não existisse este lugar, eu não sei o que teria feito. (DIX).

O Amparo Maternal me deu assim uma certeza psicológica... O Amparo me trouxe uma alegria profunda, uma vontade de viver. Eu mal me olhava no espelho e, hoje, eu me encontrei, me sinto resolvida, concentrada. ... um lugar que tem todas as atividades... (DX).

\section{Subcategoria: Percebendo a possibilidade de aprendizado}

Da mesma maneira que as regras e rotinas tolhem a liberdade, viver no Amparo apareceu também como um aprendizado de vida, pois tiveram de respeitar os limites de suas ações como acordar cedo, ter horário para o banho e ter responsabilidade, aspectos que não eram cobrados no contexto social anterior.

Para as mulheres, o que foi apreendido neste contexto social será levado como uma lição de vida. As experiências vividas farão parte de seus conhecimentos, de suas memórias e as acompanharão na trajetória de suas vidas. O conhecimento técnico adquirido nos cursos foi destacado como favorável a elas, possibilitando-lhes que obtivessem habilidades manuais que podem levar ao desempenho de alguma atividade remunerada, quando saírem da instituição propiciando, assim, melhores condições econômicas e de reintegração social.

Por uma parte é bom... Tem o curso,eu gosto do curso, eu gosto daqui, entendeu? ... aqui você aprende coisas, que não aprende lá fora, tipo regras, acordar cedo, ir para a cozinha, tem que ter responsabilidade. Tal hora tem que tomar banho, 
tal hora apagar a luz do quarto, tal hora tem que dormir ... aqui aprende regras, coisa que não aprende lá fora. (DI)

Eu acho assim, aqui é um aprendizado de vida. (DIV)

Viver aqui você aprende muita coisa, porque você convive com muitas pessoas. ... Tudo para mim foi bom, foi uma lição de vida, porque eu mesma não achava que ia conseguir viver no meio de muitas mulheres .... (DVII)

\subsubsection{Categoria 3: O Cuidado à saúde no Amparo Maternal}

As mulheres preocupam-se com a recuperação física, valorizando a compra da medicação como forma de atenção à saúde. O fato de estarem no Alojamento possibilitou que fossem tratadas de outras enfermidades que não estavam relacionadas com a gestação.

As mulheres avaliam o atendimento à saúde que receberam no Amparo como bom quando comparam aos oferecidos por outras instituições de atenção à saúde. Relatam que quando a instituição não consegue solucionar seu problema de saúde, os profissionais encaminham para outro hospital, dando continuidade e resolução a seus problemas de saúde.

No atendimento à saúde, as mulheres moradoras no Alojamento Social encontram-se em uma relação face a face com os profissionais que atuam na instituição, estabelecendo uma relação social que é intersubjetiva de motivos (Schütz, 1974b). A mulher percebe o profissional, como este também a percebe e ao compartilharem a experiência mostram-se como de fato são. Estabelecendo-se, desta forma, uma relação concreta e de significado. Neste sentido, as experiências das 
mulheres e dos profissionais estão ao alcance um do outro. Sujeitos que estão ao alcance da experiência um do outro estão na situação face a face com reciprocidade de intenções (Wagner, 1979).

Como pesquisadora, percebo na relação face a face entre as mulheres moradoras no Amparo e os profissionais que o mundo da vida diária não é um mundo particular, mas compartilhado com aqueles que vivem no mesmo espaço e tempo. Neste ambiente em comum, as mulheres perceberam o atendimento oferecido pelos profissionais e posicionaram-se em relação aos cuidados revelados nas subcategorias, como positivos que superaram suas expectativas e foram descritos como qualificados.

Na situação face a face, pensando no ponto de vista de um participante, este precisa tornar-se intencionalmente consciente da pessoa que o confronta, necessitando assumir uma orientação para o Outro, que podemos chamar de orientação para o Tu, isto é, estar consciente do outro ser humano como indivíduo (Wagner, 1979).

Diante do conhecimento da importância da assistência pré-natal, as mulheres valorizam sua realização justificando que toda a semana os profissionais chamam para a consulta para ver como está o desenvolvimento do bebê e falam sobre o estado de seu desenvolvimento. Valorizam a realização dos exames laboratoriais e as consultas paralelas às do pré-natal, como também o tratamento das intercorrências clínicas encontradas durante a gestação e o número de consultas realizadas. Fazem uma comparação do atendimento realizado no pré-natal como se elas estivessem sendo atendidas em consultório particular e não se sentem discriminadas por serem do alojamento social.

Para algumas mulheres, a assistência à saúde superou as expectativas, foi além do que elas esperavam, talvez por não entenderem que é um direito do cidadão ter 
uma assistência digna e de qualidade. Perceber a possibilidade de um bom atendimento, ajudará a estas mulheres reivindicarem sempre um tratamento digno.

As mulheres que vivenciavam a fase do puerpério, sentiram-se calmas e protegidas no momento do trabalho de parto, pois foram ouvidas e receberam orientações dos profissionais e não se sentiram sozinhas, favorecendo um trabalho de parto com maior tranqüilidade e menos ansiedade. Sabemos que a ansiedade, solidão e medo são sentimentos comuns nos momentos que antecedem o parto. A mulher grávida, emocionalmente regredida, tem o ponto máximo da regressão na fase expulsiva do parto. Neste sentido, a comunicação adequada contribui com a relação de proximidade entre as mulheres e o profissional da saúde, minimizando, assim, as adaptações emocionais.

Por outro lado, na relação face a face, em algumas situações, as mulheres do Alojamento perceberam que os profissionais não corresponderam às suas expectativas. Criticaram a falta de atenção dos profissionais no que se refere às suas explicações sobre a saúde, o fato de não serem médicos e, sim, enfermeiras que acompanham o parto normal, não podendo fazer nada caso aconteça alguma coisa mais grave.

Talvez o fato de não conhecerem as funções da enfermeira obstétrica, possa causar insegurança em relação às condutas que podem ser tomadas por ela, em momentos decisivos. É de fundamental importância que a enfermeira obstétrica posicione-se diante daquele que busca o cuidado à saúde, orientando-o sobre sua categoria profissional, esclarecendo suas funções. De certa forma, as mulheres, também, perceberam-se discriminadas pelo profissional médico, por serem moradoras no Alojamento. Acreditam que suas queixas não são relevantes para ele, pelo fato de serem mulheres moradoras no Alojamento Social. 
Para Schütz (1974b), uma comunicação eficaz é possível quando as pessoas ou grupos sociais compartilham um sistema de significado similar, portanto, quanto maior for a diferença de significado entre as pessoas menores serão as probabilidades de sucesso na comunicação.

$\mathrm{Na}$ relação social "nós dois, eu e o outro", vivenciamos o processo de comunicação em curso, em um "presente vivido" (Wagner 1979). É, nesta relação social e no presente vivido, que as mulheres comunicam-se entre elas e com os profissionais que atuam direta ou indiretamente com elas.

\section{Subcategoria: Vivenciando positivamente a atenção à saúde}

Era a vontade que eu tinha de tomar o remédio, né? Aqui eu consegui. Antes quando eu estava lá fora, eu tinha ataque epilético, não estava tomando o meu remédio... Depois que entrei aqui, me levaram para o Hospital São Paulo, conversei com o médico e ele passou o remédio, não está dando mais crise. ... melhor porque eu voltei a tomar o meu remédio, não estava agüentando mais.(DI)

...pagaram um remédio para passar... Os médicos era muito bom, não pensei que tivesse tantas coisas. No Papanicolaou, deu um probleminha, aí mandaram para o IBCC... Fora que eu fazia fisioterapia, terapia ocupacional... psicóloga... pré-natal, tudo direitinho. (DIII)

Eu não esperava que ia ser assim, é muito boa! ... remédio se não tem eles compram, se tiver outros problemas a mais eles mandam para outro hospital. Outro lugar para fazer exame,... (DVI). 
Na saúde é bom, pelo menos, isto tem que ser. Estando grávida, tão frágil, você não sabe a hora que está para ganhar, pode ter dez filho, mas um é diferente do outro. (DII)

Lá fora, a gente não tem o tratamento que tem aqui. ... Lá demora, as pessoas não ligam, aqui dão atenção adequada, ... qualquer probleminha que surge eles te escutam, ouvem, já tomam providência. (DIV)

Eu tive um problema de estômago fui no Hospital São Paulo. Eles deram a medicação, me perguntavam sempre se estava bem, até sobre a alimentação eles perguntavam se eu queria mudar. Eu até mudei de alimentação, não tenho o que reclamar. Eles me tratam muito bem (olhos lagrimejando). (DVII)

Da saúde, só tenho a agradecer, principalmente, da saúde psicológica, ... Tive pressão alta. tive ajuda, boa alimentação. (DX)

\section{Subcategoria: $\mathbf{O}$ cuidado à saúde durante a gravidez superando expectativas}

Toda a semana chama para o pré-natal, para ver como está o bebê, se está bem, se tem algum problema, então! Lá fora não, lá fora é todo o mês, aqui é toda a semana, te chama para fazer alguma coisa, ultra-som, eu, pelo menos, eu gosto. Eu estou achando muito bom. (DI)

Tipo na parte do pré-natal, eu acho muito bom, você não precisa ficar marcando consulta, se a gente esquece, eles avisam, te analisa direitinho, é bem legal o pré-natal... Em relação ao pré-natal, é bem melhor, pelo menos, elas estão ali, elas explicam as coisas para você, que você não sabe, tiram as dúvidas. (DII) 
No pré-natal, é muito legal, tratam a gente muito bem, não tratam com diferença por ser do alojamento social ... é como se estivesse pagando. (DIII)

Tem os médicos do pré-natal (enfermeiras), falam que está tudo bem com o bebê. ... as pessoas que ouvem, são as estagiárias e as médicas (enfermeira obstétrica). (DIV)

Quando cheguei aqui, eles fizeram todos os exames, marcaram pré-natal, me deram remédio. ... Eles me cuidaram da minha anemia no pré-natal. ... Minha anemia está curada. (DV)

... aí tem o pré- natal uma vez por mês. No final, uma vez por semana. É muito bom. (DVI)

A saúde é nota dez! Porque dão muita atenção para a gente no pré-natal, a gente participava de muitas palestras, dúvidas que a gente tinha, eles esclareciam com a gente ... a estagiária do pré-natal, ela me tratou muito bem, me perguntava sobre o pai do bebê, sobre a minha filha. Eu não esperava que ia ser muito bom. (DVII).

Nossa! Muito mais do que esperava, temos muitas opções. No pré-natal, foi ótimo, conversava, não era só uma consulta, desabafava, não tenho o que reclamar, que Deus conserve este lugar! Que as pessoas continue contribuindo! (DIX)

Tive boas psicólogas, principalmente, uma me ajudou a encarar a gravidez como algo normal. Fui muito bem recebida. (DX) 


\section{Subcategoria: Qualificando a atenção recebida no parto}

... no centro obstétrico... tinha um monte de profissionais, monte de estudante, as médicas. Não deixam sozinhas, tinha um monte de doulas. Tinha três doulas comigo até ganhar o bebê, eu fiquei bem tranqüila ... não senti nada, ficava conversando, aí a gente se distrai, as médicas um amor de pessoa (enfermeiras obstétricas do Centro de Parto Normal) (DIII)

... no centro obstétrico, a enfermeira foi excelente, deu atenção. (DVII)

As doulas me ajudaram, a pastoral da escuta também me ajudou. Na clínica (Centro de Parto Normal), a médica (enfermeira obstetra) me atendeu com calma, conversou comigo me acalmando, aí foi bom. (DVIII)

Centro Obstétrico foi ótimo, estava tranqüila, fui muito bem atendida, tive ajuda de uma voluntária carinhosa, ficou o tempo todo comigo. No Alojamento (Alojamento Conjunto) foi bom os estagiários (chorando). Estou emocionada. Às vezes, nós pensamos que temos muitos problemas, mas outras pessoas têm mais. (DIX)

Mesmo a mulher tendo vivido recentemente a experiência do parto, situação que a predispõe à introspecção, é interessante ressaltar neste depoimento, que ela pode refletir sobre sua situação, sua realidade e perceber que outras mulheres encontravamse em situações mais delicadas, emocionando-se. 


\section{Subcategoria: Criticando o cuidado à saúde oferecido}

Agora muito, muito, o que me magoou foi no CO (Centro de Parto Normal). Pelo que fiquei sabendo, que as mães têm filho até no banheiro. Eu acho que não é bem assim, esperar para a criança coroar para depois colocar na maca. Dizem que não é médico, são enfermeiras, se acontecer alguma coisa não são médicos, são enfermeiras, não podem fazer nada. ... Às vezes, a gente não está muito bem, e eles acham que é frescura da gente. Eu estou seis meses aqui, e nunca subi lá em cima... Só subi uma vez, mas fui bem atendida, pela médica e pela enfermeira. Mas, às vezes, tem um estresse do médico. ... Ah, não gosto de ser atendida pela estagiária. Elas perguntam tudo de novo e machucam, não sabe o que falam. Elas ficam sozinhas com a gente, a enfermeira não fica junto, ela fala que tem outra coisa para fazer, e não dá para ficar o tempo todo. Eu não quero ser atendida mais pelas estagiárias. Mas de resto, o atendimento à saúde é bom. (DII)

Neste depoimento, é interessante notar que a mulher sentiu-se magoada com a experiência vivida por outra, entendendo ter sido uma experiência negativa, conseqüentemente, transferiu para si a possibilidade da mesma vivência. Assim, tomou consciência de seu semelhante como ser humano que viveu a experiência de quase dar à luz no banheiro, independente se quem viveu a experiência a tenha visto como semelhante, também. Diante disso, identifica-se a orientação para o Tu, unilateral, como referido por (Wagner, 1979).

O sentimento de mágoa em função da assistência refere-se, também, à experiência vivida diretamente por ela. Nesta situação, a mulher criticou a assistência, pontuando exatamente em qual momento sentiu não ter recebido um cuidado 
adequado. No entanto, em outras situações de atendimento à saúde, as mulheres demonstraram que foram bem atendidas.

Fora alguns errinhos ... O médico (admissão) não sabe explicar, o que a gestante tem, fizeram um monte de exame e não descobriram o que eu tinha.(DII)

...mas tipo assim, lá em cima (admissão) eles nem examinam direito. Eles sabem que a gente é do Alojamento, eles acham que a gente não tem nada, às vezes, porque uma vai por qualquer coisa, as outras pagam. (DVI)

\subsubsection{Categoria 4: Retornando ao cotidiano com novos projetos}

Nesta categoria, fica explícito o forte motivo para as mulheres moradoras da instituição social e de saúde, cenário deste estudo, retornarem a seu cotidiano, tendo uma expectativa de melhora de vida.

Percebi que as mulheres apresentaram projetos futuros em dois momentos; o primeiro, ao procurarem a instituição como forma de obter acolhimento e condições de mudança de vida; e o segundo, quando pretendem retomar seu cotidiano projetando uma vida melhor.

Ao retornarem ao cotidiano, as mulheres são estimuladas a projetarem atos futuros, que vêm ao encontro de seus propósitos, ou seja, obterem condições de uma vida melhor. Toda ação é a execução de um ato projetado e esta ação é espontânea e subjetiva orientada para os objetivos futuros, motivo para, ou seja, o que se pretende alcançar com uma determinada ação; os homens têm razões para suas ações e estas estão enraizadas em experiências passadas que são denominadas de motivos por que (Schütz, 1974b). 
Na minha compreensão, ao saírem da instituição, as mulheres esperam conseguir realizar seus sonhos, que se relacionam à mudança de vida e à busca da felicidade. Querem esquecer as coisas ruins pelas quais passaram, sonhando com um futuro brilhante tanto para elas como a seus filhos. A conquista do sonho depende de suas próprias ações e também de obter ajuda.

A princípio, o sonho foi sendo desenhado nos discursos como algo possível de ser realizado, porém sem nenhuma estratégia concreta ou efetiva para consegui-lo. Estava na fantasia, no imaginário, porém, as mulheres começaram a traçar a maneira que iriam conseguir este sonho de uma vida melhor, saindo da fantasia e passando para a intenção de realização. Pelos depoimentos, percebi um significado muito forte às mulheres, que é não retomarem o seu dia-a-dia como viviam antes, carregado de problemas sociais.

Cuidar do filho que nasceu proporciona força às mulheres para seguirem em frente. Pelos discursos, foi possível notar que o trabalho é a principal maneira vista por elas de darem os cuidados maternos necessários. Para que possam trabalhar, percebem a necessidade de ter um local para os seus filhos ficarem e vêem na creche a melhor opção.

Projetar um lugar para morar, "ter o seu cantinho, suas coisinhas", é obter de volta aquilo que perderam quando, diante da descoberta da gravidez, vivenciaram a sensação de estar sem rumo, sem um teto para se abrigar. Para as mulheres do Alojamento do Amparo, compreendo que sonhar com um futuro melhor, traçar planos para o futuro significa manterem-se vivas, determinadas a algo. As novas ações trarão outras experiências que serão vividas por elas e compartilhadas com seus semelhantes e, assim, cada uma seguirá seu caminho. 
As dificuldades socioeconômicas e os conflitos familiares dessas mulheres resultaram no afastamento de seus filhos, como também dos membros da família. Quando retornar ao cotidiano, este grupo social de mulheres estará motivado para recuperar a condição de mãe que tinham antes e, também, para resgatar o convívio com alguns familiares que tenham um significado de importância para elas.

Embora o projeto de obterem uma vida melhor tenha sido elaborado, de antemão as mulheres não sabem quais alternativas as levarão, com certeza, para o fim desejado. No entanto, podem imaginar quais caminhos consideram mais apropriados. Quando os motivos para foram elaborados, as mulheres fizeram uso de seu estoque de conhecimento, ou seja, de suas experiências anteriores. Wagner (1979) diz que só, retrospectivamente, o ator verá se o seu projeto resultou no que foi esperado por ele.

Ser alguém na vida, esquecer as coisas ruim que passou, coisa ruim fica para trás, pensar em coisa boa, pensar em cuidar do meu filho e ser alguém na vida. ... correr atrás de meu sonho. Não vou ficar esperando alguém me dar nada, ... Se você não correr atrás e conseguir por suas próprias mãos você não vai dar valor, ... (DI)

Quero ter minhas coisinhas, toda menina aqui dentro sonha em ter seu cantinho, suas coisinhas para poder cuidar. (DIV)

Tenho uma visão do meu futuro bem brilhante, bem mais brilhante do que antes. ... Agora os meus sonho é mais colorido do que antes. Para este menino tenho vários sonhos, ... (DX)

... cuidar do meu filho, e ser feliz... Agora quero pensar em meu filho e seguir para frente... Agora é pensar para frente, arrumar um emprego, fazer faculdade. Se Deus permitir alguma coisa boa, irá acontecer,... só Deus sabe (DI) 
...ver se conseguia um emprego, trabalhar para eles (filhos). Quando for embora, só eu, só eu, para eles. Trabalhar, ganhar alguma coisa, para morar, para ter eles de volta. Vou ter que caçar serviço, para depois cuidar deles. (DII)

...vou arrumar um serviço para mim. Vou trabalhar, cuidar de minhas filhas, ajudar a minha mãe... Vou ser pai e mãe dela. (DV)

Quando eu sair, eu quero arrumar um trabalho, casa, e os meus filhos de volta ... (DVI)

Procurar um serviço, ... ir embora com minha filha, cuidar de minha filha... volta a trabalhar como cabeleireira, alugar uma casa, viver individualmente eu e meu filho, fazer supletivo, tirar minha carta de motorista. Tenho que ter minha responsabilidade como cuidar, com quem deixar, meu futuro será muito brilhante (DX)

A primeira coisa, até quatro meses, vou ficar em casa, porque a minha mãe está desempregada. Ela faz faxina, tem que pagar aluguel. Depois, colocar na creche e procurar um serviço, para poder comprar as coisas para ela e para o meu irmão. Já que o meu pai não dá nada, vou cuidar do meu irmão e da minha filha. (DIII)

Continuar procurando a minha mãe e a minha filha é lógico, né? (DI)

Quando eu sair, eu quero arrumar um trabalho, casa. E os meus filhos de volta, sinto muita falta deles. Eles moram com a minha vó, quero arrumar uma casa e arrumar trabalho, porque senão vou voltar para esta vida de novo. (DVI)

Cuidar dos meus filhos, principalmente, do neném, por ele ser pequeno. ... ir pegar o meu filho que mora com a minha prima. Meu sonho é poder alugar uma casa e trabalhar. Eu pretendo ficar um tempo em São Paulo juntar alguma coisa, para eu poder ir embora, para perto do meu pai, dos meus irmãos... (DVII) 
Pretendo colocar na creche, voltar a trabalhar e construir uma família, já que eu não pude ter minha família lá atrás. Eu posso ter agora, e quero contar para o pai dela que eu estava grávida. Meu pai quer que eu vou atrás dele, para ele pagar a pensão. (DVIII)

Quando for embora com a minha filha, vou arrumar um serviço para mim. Vou pagar minha irmã para cuidar dela, e depois ela vai para a creche. Vou trabalhar, cuidar de minhas filhas, ajudar a minha mãe. Se minha filha perguntar do pai, vou dizer que ele morreu (sorri), vou ser pai e mãe dela. (DV)

Quando for embora, pretendo amamentar ... período certo... Vou colocar na creche, ir trabalhar ... Quero ter minhas coisinhas... e viver minha vida. Eu, o meu filho e meu marido. O pai do meu filho ... está em albergue ... Aí quando ele arrumar um lugar, eu vou morar com ele, com ele. (DIV) 
6 CONSTRUÇÃO DO TIPO VIVIDO 


\section{CONSTRUÇÃO DO TIPO VIVIDO}

A fenomenologia tem como tarefa analisar as vivências intencionais da consciência para aí perceber o sentido do fenômeno. Ao elaborar e examinar as categorias que emergiram neste estudo, foi possível construir o tipo vivido de mulheres que vivenciaram o processo gravídico morando no Amparo Maternal, instituição social e de saúde.

Capalbo (1979) refere que na vida do dia-a-dia realizamos tipificações, porém não somos tipos fixados. Existe uma margem de liberdade, é por isso que podemos cessar de desempenhar o papel que o tipo nos havia imposto. A tipologia deve sintetizar os traços típicos de um fenômeno social.

O tipo vivido dessas mulheres constitui um comportamento do grupo social que vivencia o mesmo fenômeno e não o comportamento individual, portanto, este comportamento social é constituído pela interação das pessoas que desenvolvem suas ações com intenção de alcançar um determinado objetivo.

Neste estudo, desvelou-se o tipo vivido "mulheres que vivenciam o processo gravídico morando em uma instituição social e de saúde", como aquele grupo social que, buscando soluções para os conflitos decorrentes da gravidez, procura ser acolhido e mudar sua condição de vida. No dia-a-dia no Alojamento Social, convive positiva e negativamente com a experiência do outro, sente-se em casa, mas também sente falta dos familiares e privação da liberdade, gerando solidão. Percebe receber apoio e a possibilidade de aprendizado. Vivencia positivamente o cuidado à saúde, considera que o cuidado durante a gravidez superou as expectativas, que a atenção recebida no parto é de qualidade, pôde avaliar e criticar o cuidado à saúde oferecido. 
Após o alcance da solução buscada e a experiência vivida no dia-a-dia no Alojamento do Amparo Maternal, este grupo social retorna ao cotidiano com novos projetos. 
7 INTERPRETANDO

O TIPO VIVIDO 


\section{INTERPRETANDO O TIPO VIVIDO}

\subsection{MULHERES QUE VIVENCIAM O PROCESSO GRAVÍDICO, MORANDO EM UMA INSTITUIÇÃO SOCIAL E DE SAÚDE}

As mulheres que vivenciaram o processo gravídico, morando em uma instituição social e de saúde apresentaram reciprocidade de intenção no cenário social em que compartilharam as mesmas experiências.

O tipo vivido mostra aquela mulher que percebe sua vivência no processo gravídico como moradora no Amparo Maternal com ganhos, quando manifestou que essa instituição recebeu as mulheres que não tinham para onde ir, tirando-as das ruas e oferecendo abrigo. Receberam apoio necessário durante a gestação, destacando-se a alimentação e a tranqüilidade, porque receberam cuidados para sua saúde, garantindo a sobrevida de ambos, mãe e filho. Tiveram esperança de que vivenciar a gravidez morando na instituição, possibilitasse mudança de vida, ou seja, que pudessem mudar suas atitudes diante das adversidades.

O sentido de perda está relacionado à dificuldade nas relações pessoais, demonstrando-se incomodadas com as diferentes maneiras de comportamento entre as mulheres. Sentem solidão, falta da família e da liberdade, apontam a necessidade de respeitar as normas da instituição como causa para sentirem-se aprisionadas.

Acreditam em um futuro melhor, tanto para elas como a seus filhos, projetam ações futuras para conseguirem seus objetivos. Demonstram preocupação com o bem-estar de seus filhos e com eles desejam a construção de uma nova família. 
A gravidez pode ser uma experiência marcante na vida da mulher, carregada de significados que podem ser positivos ou negativos. A priori, a gestação poderá ser vivenciada pela mulher de forma negativa, mas, com o passar do tempo começa a experienciá-la positivamente.

Ansiedade, angústia e solidão são sentimentos comuns durante a gestação, podendo ou não ser passageiros. As causas que levam as mulheres grávidas a estes sentimentos estão relacionadas à necessidade de proteção exagerada, percepção das modificações do organismo materno, o trabalho de parto prematuro, início do trabalho de parto, a morte no parto e criação do filho (Soifer, 1992). A ansiedade própria da gravidez, somada aos problemas sociais das mulheres podem intensificar o estado de ansiedade e angústia.

Neste sentido, acredito ser de fundamental importância para o profissional da saúde contextualizar a vivência da mulher no processo gravídico, para prestar uma assistência mais voltada às suas necessidades.

Embora o foco principal da pesquisa não fosse a experiência das mulheres antes de morarem no Alojamento Social, compreendi que elas vivenciavam, em alguns momentos, conflitos socioeconômicos e situação familiar desfavorável. Isto impossibilitou a permanência naquele contexto social e familiar no qual viviam, impulsionou-as a saírem de casa, muitas vezes, sem rumo, o que poderia influenciar negativamente no curso da gestação.

Vários autores concordam que a população de baixa renda e que não possui moradia fixa, é mais suscetível às doenças. O difícil acesso à saúde contribui para que o indivíduo abandone o tratamento ou nem consiga iniciá-lo (Killion, 1995; Weinreb, Goldberg, Perloff 1998). 
Diante desta situação, compreendi que as gestantes vieram de um contexto particular e procuraram a instituição buscando solucionar seus problemas sociais agravados pela gestação, “a minha expectativa é que ia me ajudar”. Na atitude natural, as mulheres buscam solucionar os seus problemas, que devem ser compreendidos pelos profissionais da área da saúde. A adoção desta atitude é um primeiro passo para o oferecimento de uma assistência digna a elas. Se as gestantes procuraram acolhimento, cabe aos profissionais acolhê-las de forma que seus problemas sejam minimizados e nossas ações estejam, de acordo as suas necessidades, inteirando-se e considerando o contexto social em que elas viviam. Devemos continuar oferecendo assistência às mulheres da mesma maneira como idealizada por Madre Domineuc, sem distinção de classe social e raça.

Madre Domineuc atendia a quem fosse procurá-la, tinha o interesse de ajudar as mulheres em suas necessidades reais, tais como: comer, vestir e hospedar-se, oferecendo a elas também oportunidade de recomeçarem uma nova vida (Largura, 2007).

Utilizar a fenomenologia sociológica possibilitou-me compreender que o diaa-dia das mulheres moradoras no Amparo Maternal tem forte significado de ganhos e perdas e que também deve ser compreendido pelos profissionais que as assistem. Viver com o outro, compartilhar as experiências vividas no mundo do dia-a-dia contribui com o aprendizado do indivíduo. Pensando, assim, as mulheres que vivenciaram juntas o processo gravídico aprenderam conviver com seus semelhantes, contribuindo com sua bagagem de conhecimento, como pode ser visto neste depoimento "a gente aprende a conviver com pessoas diferentes da gente". 
Consideram a experiência com o outro nessa relação social benéfica, pois aprenderam a conviver com a diversidade, tiveram "um aprendizado de vida". Ao vivenciarem o processo gravídico, morando em uma instituição social e de saúde, as mulheres colocaram-se de forma direta umas com as outras e também com os profissionais que as assistiram, ultrapassando a intersubjetividade, que é um "datum" do mundo da vida (Schütz, 1974b).

$\mathrm{Na}$ relação face a face entre elas e os profissionais, de um modo geral, vivenciaram positivamente suas experiências, justificando este ganho quando estabeleceram um relacionamento favorável com a experiência do outro, sentindo como se a instituição fosse a continuidade de sua casa, "aqui é como se estivesse em casa com um monte de irmão", recebendo apoio e cuidado necessário à saúde materna que, muitas vezes, superou as expectativas e proporcionou a tranqüilidade que passaram a ter diante da gestação.

Como pontos positivos do cuidado à saúde foram apontadas as orientações técnicas sobre o bem-estar do bebê, o esclarecimento das dúvidas, a resolução de problemas encontrados, a compra dos medicamentos, o número de consultas durante o pré-natal, a possibilidade de serem ouvidas e poderem falar. Valorizaram quando o profissional permaneceu ao lado "fui muito bem atendida, voluntária carinhosa, ficou o tempo todo comigo". Nesta relação social as mulheres compararam a assistência recebida no Amparo Maternal com outras instituições de saúde em que haviam sido atendidas anteriormente. Assim, fizeram por já terem refletido sobre as experiências passadas. Por sentirem dificuldade no cuidado à saúde recebido em outros contextos, valorizaram a assistência oferecida na Instituição. 
No estudo de Bonadio, Tsunechiro (2003), os pontos relevantes relatados pelas mulheres que receberam assistência durante o pré-natal no Amparo Maternal não apenas do contexto do Alojamento Social, foram semelhantes a esta pesquisa. A pesquisa revelou que o cuidado pré-natal transformou a vivência da gravidez com sentimentos predominantemente negativos em vivência positiva. Assim, proporcionou segurança e confiança, possibilitando crescimento emocional às mulheres. A comunicação contextualizada e personalizada utilizada pelas enfermeiras do pré-natal foi o que possibilitou o atendimento das necessidades das mulheres, que buscaram o cuidado profissional, reforçando a importância de uma equipe de saúde atenta às necessidades da clientela e envolvida com o atendimento da pessoa em todas as suas dimensões, integrando os aspectos técnicos e expressivos da assistência.

Compreendo que a vivência de cuidado de saúde das mulheres, não está somente relacionada aos procedimentos técnicos e ao âmbito biológico, mas também ao fato de serem tratadas como seres humanos. Nessa condição, necessitam de cuidados que ultrapassam os aspectos técnicos que, para mim, envolvem o oferecimento de calor humano. É possível perceber essa ação na fala das mulheres: “escutam...”, “ouvem...”, “tratam bem...”, “desabafo...”, “não tratam com diferença por ser do social...”, “me ajudou a encarar a gravidez como algo normal...".

As mulheres que recebem cuidado em saúde em hospitais públicos, de forma geral, não esperam receber tratamento individualizado ou uma atenção mais carinhosa mesmo no momento do parto (Dias, Deslandes, 2006). Neste estudo, pelo fato de não terem sofrido nenhuma situação de violência institucional, as mulheres 
consideraram bom o cuidado oferecido. Fica claro que, nesta situação, a mulher vivenciou a experiência de ser cuidada sem conhecer seus direitos à saúde.

Neste contexto social, as mulheres tiveram perdas, "viver aqui não é fácil para ninguém, a gente fica presa, parece um tipo de presídio”, "ficar aqui grávida não é bom, a gente fica muito carente”, pois em alguns momentos sentiram falta dos familiares, solidão, privação da liberdade e fizeram críticas ao cuidado à saúde que receberam.

Tendo compreendido que as mulheres moradoras do Amparo Maternal vivenciaram perdas, cabe aos profissionais de saúde fazer uma reflexão sobre os sentimentos e vivência do processo gravídico por mulheres nestas condições.

É necessário estabelecer uma maneira sistemática de integração de trabalho com outros profissionais que participam na assistência a estas mulheres, como os médicos, assistentes sociais, psicólogas e fisioterapeutas, tendo como objetivo a integralidade da assistência. Acredito que considerar e discutir, rotineiramente, com outros profissionais as condições sociais e as necessidades específicas demonstradas pelas mulheres em seu dia-a-dia contribuirão para diminuição das sensações e experiências de perda.

As mulheres mostraram que, ao vivenciarem o processo gravídico em contexto especial e repleto de significado e de motivos para, foram estimuladas a projetarem atos futuros que, de certa forma, foram motivados, mediante reflexão de suas experiências antes de serem moradoras no Alojamento Social. Sendo assim, não pretendem retomar o cotidiano, como era vivido anteriormente, mas retornarem ao cotidiano com novos projetos. Compreendo que, quando o indivíduo mantém ou recupera sua auto-estima, acredita ter possibilidade de mudança e, é neste sentido 
que, como profissionais da saúde devemos estimulá-las para que se viabilize a esperança de um futuro melhor.

Sabemos que ao retornarem ao cotidiano, embora outras experiências também tenham acontecido para aquelas pessoas que conviviam com as mulheres e que já não são exatamente como eram, muito provavelmente, os conflitos sociais ainda estejam presentes e, de certa forma, poderão representar para elas dificuldades na realização de seus sonhos. O importante é que este grupo social de mulheres conseguiu projetar novos caminhos para suas vidas. Estes novos projetos, desde que concretizados, darlhes-ão oportunidade de mudança de vida. Este é o primeiro passo para que de fato as mudanças ocorram e o "sonho de uma vida melhor" seja alcançado.

Desta forma, interpreto o tipo vivido, mulheres que vivenciam o processo gravídico, morando em uma instituição social e de saúde, desvelado neste estudo, como o daquele grupo social que "vivendo uma relação social de ganhos, de perdas e sonhando com um futuro melhor" poderá ter condição de reintegração social e lutar pela conquista de seus sonhos. 
8 CONSIDERAÇÕES 


\section{CONSIDERAÇÕES}

A fenomenologia social de Alfred Schütz permitiu que eu compreendesse as ações e os projetos das mulheres que vivenciaram a maternidade em um contexto particular, então, observo que este estudo respondeu às minhas indagações.

A possibilidade de compreender como as mulheres vivenciaram o processo gravídico morando em uma instituição social e de saúde, contribuiu para que eu tenha um novo olhar às relações sociais, às experiências do outro e aos motivos que os levam para a estas ações. Não só as mulheres do estudo, mas, a todas as que vivenciam o processo gravídico dentro de um contexto social específico. Mesmo que a experiência de outro grupo de mulheres não seja a mesma vivida pelas mulheres moradoras no Alojamento Social, posso encontrar semelhanças de necessidades sociais e de saúde que, também, demandam ações específicas. Se antes do estudo, eu compreendia a necessidade de ouvi-las, dar a liberdade de falar, estar perto, ajudando a solucionar seus problemas, a partir de agora o farei com muito mais propriedade, atenta para aquilo que elas vieram buscar.

Na relação social intersubjetiva de mulheres inseridas temporariamente em um espaço comum de experiência, foi relevante observar que, em certos momentos, eu também fiz parte daquele cotidiano e compartilhamos o mesmo ambiente. Conscientizei-me de que essas mulheres são elementos de minha própria situação biográfica e vice-versa (Wagner, 1979). Desta forma, percebo com muito mais propriedade, aquele ambiente como um espaço de compartilhamento com as mulheres, e que faço parte de suas experiências como elas das minhas. 
Sinto-me estimulada a oferecer cada vez mais o melhor de mim, para que as mulheres vivenciem esta experiência com muito mais ganhos e se houver perdas que estas sejam minimizadas. Entendo que na vida cotidiana do homem não só ganhamos, perdemos também e, sem dúvida nenhuma, aprendemos com as duas situações, mas se pudermos contribuir como profissional da saúde para que as perdas não tragam danos ao indivíduo estaremos cumprindo nosso papel.

A desigualdade social em nosso País, que gera problemas sociais e de saúde que são agravados quando acontece a gravidez, assim, o Amparo Maternal aparece na vida das mulheres, como uma alegria; esperança; ajuda; ser assistida com dignidade; uma luz no fim do túnel. E é exatamente essa luz que devemos manter acesa, para que possamos dar continuidade ao objetivo de Madre Domineuc: oferecer acolhimento a todas as mulheres que necessitarem da instituição. Esta é uma possibilidade de reintegração social.

Embora com todas as dificuldades financeiras que o Amparo Maternal enfrenta em sua trajetória assistencial, a filosofia de Madre Domineuc mantém-se viva pela existência de pessoas que acreditam e possibilitam o atendimento das mulheres dos quatro cantos do Pais, já que é a única instituição que oferece à mulher um atendimento que garante abrigo, alimentação, acolhimento espiritual, assistência à saúde para elas e seus filhos, além de cursos de capacitação profissional, contribuindo para sua reintegração social.

Diante da difícil manutenção desta instituição para atendimento às gestantes, as autoridades brasileiras poderiam olhar com mais carinho e contribuir mais efetivamente nessa ação social, para que ela nunca deixe de existir e possa continuar contribuindo com as questões sociais e de saúde de nossa população de mulheres 
grávidas em situação de risco social que escolhem, buscam e são encaminhadas para receberem a assistência durante a gestação.

Embora, existam políticas e programas de saúde voltados à saúde da mulher, sabemos que as necessidades das mulheres que vivenciam a gravidez em um contexto específico não são supridas.

Na qualidade de docente do Curso de Graduação em Enfermagem e PósGraduação em Enfermagem Obstétrica, reflito o quanto é importante para a formação do aluno e futuros profissionais da área da saúde da mulher, discutirmos os aspectos sociais, as experiências de vida trazidas pelas mulheres, como vivenciam a gestação dentro de seu contexto social, seus projetos futuros e não ficarmos presos, muitas vezes, aos conhecimentos biológicos e, sim, ir além, a fim de garantir uma formação acadêmica de melhor qualidade.

A pesquisa contribuiu para que aumentasse meu interesse em continuar estudando e aprofundando-me no referencial da fenomenologia social de Alfred Schütz, para utilização em novos trabalhos, pois o foco de maior interesse no cuidado com a saúde da mulher está voltado à compreensão de suas experiências, diante da saúde reprodutiva. Sendo assim, pretendo integrar-me a um grupo de pesquisa para continuar realizando estudos, por considerar que o doutorado proporcionou-me os primeiros passos rumo a um novo horizonte.

A fenomenologia social deu sentido na minha vida pessoal, pois fez com que voltasse a refletir sobre minhas próprias experiências passadas, o porquê de minhas ações, as relações sociais do meu cotidiano, os meus projetos de vida, a médio e longo prazo, enfim, fez-me questionar minha própria vida. 
9 REFERENNCIAS 


\section{REFERÊNCIAS}

Alves AM, Coura Filho P. Avaliação das ações de atenção às mulheres sob violência no espaço familiar, atendidas no centro de apoio à mulher (Belo Horizonte) entre 1996-1998. Cienc Saúde Coletiva. 2001;6(1):1-18.

Alvarado R, Medina E, Aranda W. El efecto de variables psicosociales durante el embarazo, em el peso y la edad gestacuinal del recien nascido. Rev Méd Chile. 2002;130(5):1-10.

Andrade CLT, Scwarcwald CL, Gama SGN, leal MC. Desigualdades sócioeconômicas do baixo peso ao nascer e da mortalidade perinatal no Município do Rio de Janeiro. Cad Saúde Pública. 2001;20(Supl 1):44-51.

Amazarray MR, Machado OS, Oliveira VZ, Gomes WB. A experiência de assumir a gestação na adolescência: um estudo fenomenológico. Psicol Reflex Crit [periódico na internet]. 1998 [citado 2006 mar. 02];11(3):431-40. Disponível em: http://www.scielo.br/scielo.php?script=sci_arttext\&pid=S0102-

$79721998000300004 \& \operatorname{lng}=\mathrm{en} \& \mathrm{nrm}=\mathrm{iso} /$.

Ávila AM. Socorro doutor: atrás da barriga tem gente. São Paulo: Atheneu; 1999.

Balcazar H, Hartner J. The effects of prenatal care utilization and maternal risk factores on pregnancy outcome between mexican american and non-hispanic white. $\mathrm{J}$ Natl Med Assoc. 1993;85(3):195-202.

Bassuk EL, Weinreb LF, Buckner JC, Browne A, Salomon A, Bassuk SS. The characteristics and need of sheltered homeless and low. Income housed mother. Jama. 1996;276(8):640-6.

Bello AA. Fenomenologia e ciências humanas. Bauru: Universidade do Sagrado Coração; 2004.

Bloom KC, Bednarzyk MS, Devitt DL, Renault RA, Teaman V, Loock DM. Barriers to prenatal. J Obstet Gynecol Neonatal Nurs. 2004;33(4):428-34.

Bogdan R, Taylor SJ. Introduction to qualitative research methods the search for meanings. $2^{\text {a }}$ ed. New York: John Wily \& Sons; 1984.

Bonadio IC. "Ser tratada como gente". A vivência de mulheres atendidas no serviço de pré-natal de uma instituição filantrópica [tese]. São Paulo: Escola de Enfermagem, Universidade de São Paulo; 1996.

Bonadio IC, Tsunechiro MA. A experiência vivenciada por mulheres grávidas no contexto de um serviço de pré-natal. In: Merighi MAB, Praça NS. Abordagens teórico-metodológicas qualitativas: a vivência da mulher no período reprodutivo. Rio de Janeiro: Guanabara-Koogan; 2003. p. 81-91. 
Bonadio IC, Tsunechiro MA. Diagnóstico de gravidez. In: Barros SMO. Enfermagem no ciclo gravídico-puerperal. São Paulo: Manole; 2006. p. 3-18.

Brasil. Ministério da Saúde. Parto, aborto e puerpério: assistência humanizada à mulher. Brasília; 2001.

Brasil. Ministério da Saúde. Conselho Nacional de Saúde. Resolução n. 196 de 10 de outubro de 1996. Diretrizes e normas regulamentadoras da pesquisa em seres humanos. Mundo Saúde. 1996;21(1):52-61.

Campoy MA. O ensino de enfermagem em saúde mental e psiquiátrica: uma visão fenomenológica social na perspectiva do professor e do aluno. [tese]. São Paulo: Escola de Enfermagem, Universidade de São Paulo; 2003.

Capalbo C. Metodologia das ciências sociais. A fenomenologia de Alfred Schütz. Rio de Janeiro: Antares Universitária; 1979.

Capalbo C. Metodologia das ciências sociais. A fenomenologia de Alfred Schütz. $2^{\mathrm{a}}$ ed. Londrina: UEL; 1998.

Caravantes L. Violência intrafamiliar em la reforma del sector salud. In: Costa AM, Merchán Hamann E, Tajer D, organizadores. Saúde, equidade e gênero: um desafio para as políticas públicas. Brasília: UnB; 2000. p. 18.

Carvalho A de S. Metodologia da entrevista: uma abordagem fenomenológica. $2^{\mathrm{a}}$ ed. Rio de Janeiro: Agir; 1991.

Castro R, Ruiz A. Prevalência y severedad de la violência contra mujer embarazadas México. Rev Saúde Pública. 2004;38(1):62-70.

Chizzotti A. Pesquisa em ciências humanas e sociais. 6ª ed. São Paulo: Cortez; 2003.

Curry MA. Factors associated with inadequate prenatal care. J Community Health Nurs. 1990;7(4):245-52.

Dartigues A. O que é a fenomenologia? 9a ed. São Paulo: Centauro; 2005.

Dias MAB, Deslandes SF. Expectativas sobre a assistência ao parto de mulher usuárias de uma de uma maternidade pública do Rio de Janeiro: os desafios de uma política pública de humanização da assistência. Cad Saúde Pública. 2006;22 (12):2647-55.

Demo P. Pesquisa e informação qualitativa. 2a ed. São Paulo: Papirus; 2004.

Dessen MA, Braz MP. Rede social de apoio durante transição familiares decorrentes do nascimento de filhos. Psicol Teor e Pesq [periódico na internet]. 2000 [citado 2005 set. 20];16(3):221-31. Disponível em: http://www.scielo.br/pdf/ptp/v16n3/4809.pdf 
Fini MI. Sobre a pesquisa qualitativa em educação, que tem a fenomenologia como suporte. In: Bicudo MAV, Espósito VHC. Pesquisa qualitativa em educação. Piracicaba (SP): UNIMEP; 1994.

Fustinoni SM. As necessidades de cuidado da parturiente: uma perspectiva compreensiva da ação social [tese]. São Paulo: Escola de Enfermagem, Universidade de São Paulo; 2000.

Giorgi A. Phenomenology and psychological research. Pittsburg: Duquesne University Press; 1985.

Godinho R A, Schelp JRB, Parada CMGL, Bertocello NMF. Adolescentes e grávidas: onde buscam apoio? Rev Latino-Am Enfermagem [periódico na internet]. 2000 [citado 2005 out. 19];8(2):25-32. Disponível em: http://www.scielo.br/pdf/rlae/v8n2/12414.pdf.

Gomes MA, Pereira MLD. Família em situação de vulnerabilidade social: uma questão de políticas públicas. Cienc Saúde Coletiva [periódico na internet]. 2005 [citado 2005 set. 20];10(2): 357-63. Disponível em: www.scielo.br/pdf/csc/v10n2/a13v10n2.pdf.

Gomes R. A violência enquanto agravo à saúde de meninos que vivem nas ruas. Cad Saúde Pública. 1994;10(Supl 1):1-16.

Guillermin I, Rieubland C, Fioretta G, Luisier V: Perfil de las usuárias de la casa materna de Matagalpa: investigación sobre lãs 149 mujeres albergadas em la casa materna de Matagalpa em mayo-junio 99. Matagalpa: Casas Maternas; 1999. 18 p.

Jeneral RBR. Vivendo um futuro incerto: a vivência da gravidez em uma comunidade [dissertação]. São Paulo: Escola de Enfermagem, Universidade São Paulo; 2000.

Killion CM. Special health care needs of homeless pregnant women. ANS Adv Nurs Sci. $1995 ; 18(2): 44-56$.

Largura M. Uma história de amor verdadeiro. São Paulo: Do Autor; 2007.

Lüdke M, André MEDA. Pesquisa em educação abordagens qualitativas. São Paulo: EPU; 1986.

Maldonado MT. Psicologia da gravidez. 15ª ed. São Paulo: Atheneu; 2000.

Merighi MAB. Enfermeiras obstétricas egressas da Escola de Enfermagem da Universidade de São Paulo: caracterização e trajetória profissional [tese de livre docência]. São Paulo: Escola de Enfermagem, Universidade de São Paulo; 2000.

Mikhail BI. Perceived impediments to prenatal care among low-icome women. West J Nurs Res.1999;21(3):335-55.

Minayo MCS. O desafio do conhecimento: pesquisa qualitativa em saúde. $5^{\mathrm{a}}$ ed. São Paulo: Hucitec; 1998. p. 105-58. 
Moreira DA. Algumas variantes do método fenomenológico na pesquisa empírica In: O método fenomenológico na pesquisa São Paulo: Thomson Pioneira; 2002. Cap 10.p. 117-125.

Organización Panamericana de La Salud (OPAS). La violência contra la mujer en las Américas. Washington; 1998. 13 p. (SPP31/6 (Esp).

Ovrebo B, Ryan M, Jackson K, Hutchinoon. The homeless prenatal program: a model for empowerring homeless pregnant women. Health Educ Q. 1994;21(2):187-98.

Paéz D. Salud mental y factores psicosociales. Madrid: Fundamentos; 1986.

Piccinini CA, Silva MR, Gonçalves TR, Lopes RS, Tudge J. O envolvimento paterno durante a gestação. Psicol Reflex Crit [periódico na internet]. 2004 [citado 2005 out. 19];17(3):303-14. Disponível em: http://www.scielo.br/pdf/prc/v17n3/a03v17n3.pdf.

Rocha DS, Netto MP, Priore SE, Lima NMM, Rosado LEFPL, Franceschini SCC. Estado nutricional e anemia ferropriva em gestantes: relação com o peso da criança ao nascer. Rev Nutr. 2005;18(4):481-9.

Rosa MVFRC, Arnoldi MAGC. A entrevista na pesquisa qualitativa; mecanismo para avaliação dos resultados. Belo Horizonte: Autêntica; 2006. p. 17-27.

Sabroza AR, Leal MC, Souza Junior PR, Gama SGN. Algumas repercussões emocionais negativas da gravidez precoce em adolescentes do município do Rio de Janeiro. Cad Saúde Pública [periódico na internet]. 2004 [citado 2005 nov. 09];20(Supl 1):5130-7. Disponível em: http://www.scielo.br/pdf/csp/v20s1/14.pdf.

Schütz A. El problema de la realidad social. Compilador Maurice Natasson. Trad.por Nestor Míquez. Buenos Aires: Amorrortu; 1974a.

Schütz A. Estudios sobre teoria social. Compilador Arvid Brodersen. Trad.por Nestor Míquez. Buenos Aires: Amorrortu; 1974b.

Silva LL, Coelho EBS, Caponi SNC. Violência silenciosa: violência psicológica como condição da violência física doméstica. Interface - Comunic, Saúde, Educ [periódico na internet]. 2007 [citado 2007 maio 30];11(21):93-103. Disponível em: http://www.scielo.br/pdf/icse/v11n21/v11n21a09.pdf.

Silva WV. Convivendo com obstáculos e fazendo o que se pode: a comunicação interpessoal na assistência pré-natal [tese]. São Paulo: Escola de Enfermagem, Universidade de São Paulo; 1999.

Soifer R. Psicologia da gravidez, parto e puerpério: 6 ed. Porto Alegre: Artes Médicas; 1992.

Stein A J, Lu MC, Gelberg L. Severity of homelessness and adverse Birth Outcomes. Health Psychol. 2000;19(6):524-34. 
Stein E. Mundo Vivido: das vicissitudes e dos usos de um conceito da fenomenologia. Porto Alegre: EDIPUCRS; 2004.

Strehlow AJ, Amos-Jones T. The homeless as a vulnerable population. Nurs Clin North Am. 1999;34(2):261-74.

Szejer M, Stewart R. Nove meses na vida da mulher: uma abordagem psicoanalítica da gravidez e do nascimento. São Paulo: Casa do Psicólogo; 1997. A pré-história da criança; p. 43-81.

Tuten M, Jones HE, Svikis DS. Comparing homelees and domiciled pregnant substance dependent women on psychosocial characteristics and treatment outcomes. Drug Alcohol Depend. 2003;69(1):95-9.

Valla VV. Apoio social e saúde: buscando compreender a fala das classes populares. In: Costa MV. Educação popular hoje. São Paulo: Loyola; 1998.

Velásquez AMQ. Câmbios en la dinâmica familiar durante la gestación y el posparto. Invest Educ Enferm [periódico na internet]. 1997 [citado 2005 dez. 19];15(1):109-19. Disponível em: http://tone.udea.edu.co/revista/html/modules.php?op=modload $\&$ name=Sections \&file= index \&req=downarticle $\&$ artid=147 (19 dez. 2005)

Wagner HR. Fenomenologia e relações sociais: textos escolhidos de Alfred Schütz. Rio de Janeiro: Zahar; 1979.

Weinreb L, Goldberg R, Perloff J. Health characteristcs and medical service use patterns of sheltered homeless and low-icome housed mothers. J Gen Intern Med. 1998;13(6):389-97.

Yin RK. Estudo de caso planejamento e métodos. 2aed. Porto Alegre: Bookman; 2001.

Zucchi M. Depressão na gravidez e prematuridade. Aspectos epistemológicos da investigação. Cad saúde pública. 1999;5:89-97. 
10 ANEXOS 


\section{ANEXOS}

ANEXO A

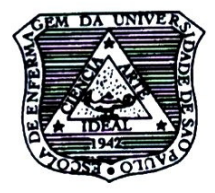

\section{UNIVERSIDADE DE SÃO PAULO} ESCOLA DE ENFERMAGEM

Av. Dr. Enéas de Carvalho Aguiar, 419 - CEP 05403-000 Tel.: (011) 3066.7602 - Fax: (011) 3066.7615

C.P. 41633 - CEP 05422-970 - São Paulo - SP - Brasil

São Paulo, 10 de julho de 2006.

IIma Sra Ir. Lydia Serrachioli Gomes

DD. Presidente Executiva do Amparo Maternal

São Paulo, SP

AVC

Sr. Emílio Ferranda

Diretor Administrativo

Encaminho à Vossa Senhoria, o Projeto de Pesquisa "A vivência de mulheres grávidas moradoras em uma instituição social e de saúde", solicitando autorização para a aluna de Pós-Graduação (doutorado) desta Escola, Soraya El Hakim Reis, sob minha orientação, realizar a coleta de dados junto às mulheres moradoras do alojamento social desta conceituada Instituição. A pesquisa tem o objetivo de "Compreender como as mulheres vivenciam o processo da maternidade afastadas de seus familiares, sendo moradoras temporárias de uma instituição social e de saúde e conhecer quais as necessidades de cuidados dessas mulheres nessa fase do ciclo vital" e faz parte do Projeto "Cuidando e Aprendendo com Gestantes", desenvolvido no Ambulatório de Pré-Natal.

Apresento o projeto de pesquisa para apreciação de Vossa Senhoria.

Agradecendo a atenção e colaboração, coloco-me à disposição para os esclarecimentos necessários.

Atenciosamente,
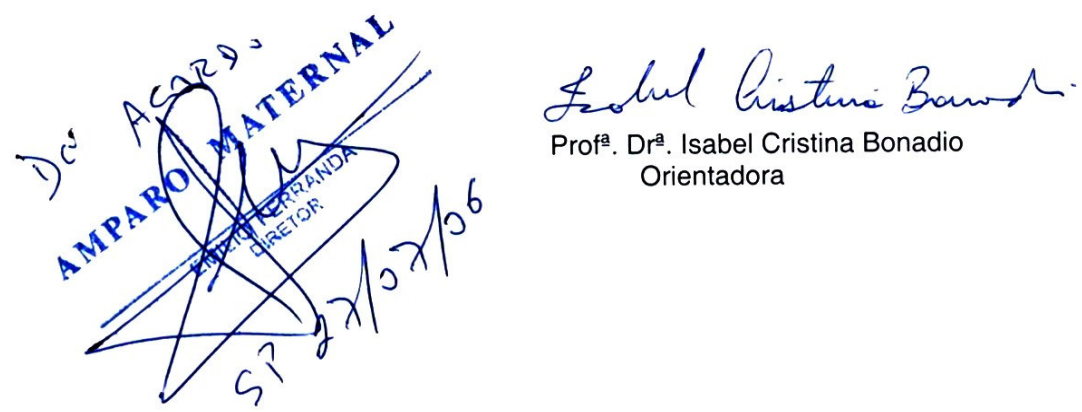

Prof $^{a}$. Dr ${ }^{\mathrm{a}}$. Isabel Cristina Bonadio Orientadora 
ANEXO B

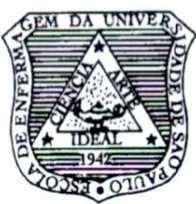

\section{UNIVERSIDADE DE SÃO PAULO ESCOLA DE ENFERMAGEM}

Av. Dr. Enéas de Carvalho Aguiar, 419 - CEP 05403-000

ori Fone.: 3066-7548 - Fax.: 280-8213

C.P. 41633 - CEP 05422-970 - e-mail.: edipesq@usp.br

São Paulo, 07 de julho de 2006.

Ilm. ${ }^{a} \mathrm{Sr}^{\mathrm{a}}$

Soraya El Hakim Reis

Ref.: Processo $n^{\circ}$ 561/2006/CEP-EEUSP

Prezada Senhora,

Em atenção à solicitação referente à análise do projeto "A VIVÊNCIA DE MULHERES GRÁVIDAS MORADORAS EM UMA INSTITUIÇÃO SOCIAL E DE SAÚDE", informamos que o mesmo foi considerado aprovado pelo Comitê de Ética em Pesquisa da Escola de Enfermagem da Universidade de São Paulo (CEP/EEUSP).

Analisado sob o aspecto ético-legal, atende às exigências da Resolução nº 196/96 do Conselho Nacional de Saúde.

Esclarecemos que após o término da pesquisa, os resultados obtidos deverão ser encaminhados ao CEP/EEUSP, para serem anexados ao processo.

Atenciosamente,

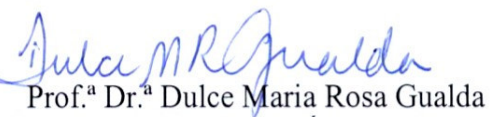

Coordenadora do Comitê de Ética em Pesquisa da Escola de Enfermagem da Universidade de São Paulo 


\begin{abstract}
ANEXO C
TERMO DE CONSENTIMENTO LIVRE E ESCLARECIDO

Pesquisa: A vivência de mulheres grávidas moradoras em uma instituição social e de saúde

\section{Registro das explicações da pesquisadora à participante da pesquisa}

Meu nome é Soraya El Hakim Reis, nº USP 3090139, sou aluna de Pós-Graduação do doutorado da Escola de Enfermagem da Universidade de São Paulo, estou fazendo uma pesquisa com mulheres moradoras do alojamento social do Amparo Maternal. O Objetivo a que me proponho neste estudo é "Compreender como as mulheres vivenciam o processo gravídico estando privadas do convívio familiar e residindo, temporariamente, em instituição social e de saúde e compreender a vivência de cuidados de saúde dessas mulheres durante este período de suas vidas".

Gostaria que você participasse desta pesquisa, caso não queira, isso não acarretará em prejuízo na continuidade do seu atendimento. Em caso positivo, irei realizar individualmente algumas perguntas, que serão gravadas para facilitar o registro das informações. Esclareço que você pode interromper a participação neste estudo em qualquer momento que julgar necessário. O que você me responder será transformado em trabalho científico, apresentado em congresso e publicado em revistas científicas da área da saúde. Assumo o compromisso de manter em segredo a sua identidade, seu nome não será revelado e você não sofrerá nenhum risco para sua saúde. Será assegurada, se assim o quiser, a sua exclusão da pesquisa a qualquer momento, por qualquer motivo e não terá nenhum prejuízo na continuidade do seu atendimento.
\end{abstract}

Agradeço a sua colaboração e para qualquer esclarecimento, poderei atendê-la no Serviço de pré-natal do Amparo Maternal, às sextas-feiras, das 7 às $12 \mathrm{hs} \mathrm{ou} \mathrm{no} \mathrm{telefone} \mathrm{(11)}$ 5573-62-03 ou (11) 30667548 USP Comitê de Ética.

\title{
II. Consentimento Pós-Informado
}

"Declaro que, após convenientemente esclarecida pela pesquisadora e ter entendido o que me foi explicado e estando ciente dos meus direitos, consinto em participar da presente pesquisa".

São Paulo, de de $200 \ldots$.

Assinatura da mulher Identidade $\mathrm{n}^{\mathrm{o}}$

Assinatura da pesquisadora: Coren - SP n 31641 


\section{ANEXO D}

\section{DEPOIMENTOS NA ÍNTEGRA}

\section{DEPOIMENTO I}

\section{- Como era o seu dia-a-dia antes de vir para cá?}

Às vezes, era bom, às vezes, era ruim, né? Às vezes, eu estava em casa bem, tinha hora que estava apanhando. Às vezes, eu tinha o que comer, às vezes, eu não tinha o que comer entendeu? Mas no fundo, no fundo, eu não queria estar aqui, né? Mas vai fazer o quê? Não tenho outro lugar para ir. Então o único jeito é ficar aqui (fica pensativa). Apesar de tudo que aconteceu, eu ainda gosto do pai desta criança, entendeu? Mesmo passando por o quê eu passei, mesmo ele falando que ia me mata. Eu não consegui tirar ele da minha cabeça, ainda, entendeu? Eu gosto dele, mas, né? Com tanta coisa ruim que aconteceu, não dá mais ... Ele já arrumou outra, já está com outra, então! Ah! Sei lá, sabe, quando você gosta muito de uma pessoa, e é capaz de fazer de tudo por aquela pessoa. Então, eu gosto dele. A semana passada, ele veio aqui. Eu gosto dele, mas se fosse para voltar com ele, não sei se voltaria, não. A pessoa não vai mudar de uma hora para outra, né? Então, se fosse para voltar com ele, não sei se voltaria, não! Sei que passaria tudo isto de novo, e é uma coisa que eu não quero. Agora quero pensar em meu filho e seguir para frente, o que foi, já foi. Agora é pensar para frente, arrumar um emprego, fazer faculdade e cuidar do meu filho, o que tiver que ser será. Se Deus permitir alguma coisa boa, irá acontecer, se não está na mão de Deus, só Deus sabe (fica pensativa). Antes de vir para cá, eu não trabalhava, só ficava em casa mesmo. Eu tinha uma filha, tinha não, eu tenho. Mas minha mãe sumiu com a minha filha, por um relacionamento que eu tive. Minha mãe não gostava desta pessoa. Não queria que eu fosse morar com esta pessoa, tinha medo que eu levasse minha filha. Então, o que minha mãe fez, pegou minha filha e sumiu com a minha filha. Faz um ano que eu não vejo a minha mãe e nem minha filha, entendeu? Foi ai que conheci o pai deste, me envolvi. Quando eu morava com a minha mãe, eu não trabalhava só estudava, quando fui morar com ele eu acabei de estudar e estava tentando entrar na faculdade. Mas como a minha mãe sumiu com a 
minha filha, resolvi procurar a minha filha. Fui para Minas, procurei em tudo que era lugar, mas não achei. Então não tenho nem idéia aonde ela está. São Paulo é grande, ela está em São Paulo, mas, aonde? Não tenho nem como procurar, não sei o que fazer (pausa).

\section{- Qual era a sua expectativa ao vir para cá?}

Para falar a verdade, nenhuma! Eu nunca vim aqui, não sabia como era, então! Eu estava morando com o pai desse aqui, ele me agrediu, né? Fui parar no hospital, tomei ponto na cabeça, certo. Ele falou para eu ir embora, ele tinha arrumado outra. Ia colocar outra dentro de casa, e que era para eu sair de dentro de casa. Aí, eu peguei e vim. Sabe quando você sai de casa sem rumo? Eu saí sem rumo. Aí uma mulher me encontrou chorando na rua, perguntou o que aconteceu, eu falei, e aí ela me falou daqui. Eu nem sabia que existia este lugar, então, não tive expectativa nenhuma, nenhuma entendeu?

\section{- Como é viver aqui neste período estando grávida?}

Por uma parte é bom, por outra não. Não é que é ruim, mais ou menos, né? Tem meninas que querem ser mais que as outras, se todo mundo está aqui é porque precisa, então! Tem muita fofoquinha, mas, de resto é bom. Porque aqui você aprende coisas, que não aprende lá fora, tipo regras, acordar cedo, ir para a cozinha, tem que ter responsabilidade. Tal hora tem que tomar banho, tal hora apagar a luz do quarto, tal hora tem que dormir, tem hora que fecha a sala de televisão. Então, quer dizer, tem hora para tudo, coisa que não tem lá fora. Lá fora a gente vê a televisão até à meia noite, duas horas da manhã e não está nem aí. Aqui não, aqui aprende regras, coisa que não aprende lá fora. A gente aprende a conviver com pessoas diferentes da gente. Assim, personalidade, né? Umas são nervosas, você aprende ter paciência, aprende conversar. Tem o curso, eu gosto do curso, eu gosto daqui, entendeu? Lógico, se eu pudesse sair daqui, tivesse um lugar para ir, lógico que eu ia. Todo mundo gosta daqui, mas se tivesse um lugar para ir, ia embora. Mas é bom, fora as conversas, as fofocas, eu gosto. Tem meninas que ficam falando da vida do outro, em vez de se preocupar com sua própria vida, se preocupa com a vida do outro. Em vez de se preocupar com que vai fazer, com o filho que vai nascer, se vai arrumar serviço. Eu não gosto de fofoca e não tenho paciência, também. Eu começo a ficar nervosa, 
então, vou para o meu quarto. Se eu ficar nervosa, não vai dá certo. E eu vou ser mandada embora daqui, então eu procuro não ficar nervosa.

\section{- O que você pretende fazer quando for embora?}

Ah, o que eu penso? Entendeu, é ir embora, arrumar um serviço, trabalhar, cuidar do meu filho, fazer uma faculdade e bola pra frente. Continuar procurando a minha mãe e a minha filha é lógico, né? Ser alguém na vida, esquecer as coisas ruins que passou, coisa ruim fica para trás, pensar em coisa boa, pensar em cuidar do meu filho e ser alguém na vida, correr atrás de meu sonho. Primeiro arrumar um serviço, faculdade não é barata, pagar alguém para cuidar de meu filho e lutar, correr atrás. Não vou ficar esperando alguém me dar nada, tudo que vem fácil, vai embora fácil, também. Se você não correr atrás e conseguir por suas próprias mãos você não vai dar valor, se os outros te der, você não vai dar valor! Você só vai dar valor naquilo que você correr atrás e lutar para conseguir. Quando você sua para conseguir você dá valor, então, tem que correr atrás, cuidar do meu filho e ser feliz. Se eu tiver que encontrar alguém, eи vou encontrar, se não tiver que encontrar, não vou encontrar. O que eu quero é ser alguém na vida!

- Como está sendo o cuidado à saúde que você recebe? Foi como você esperava?

De certa forma, é até melhor. Antes quando eu estava lá fora, eu tinha ataque epilético, não estava tomando o meu remédio, porque o médico falou que não era para mim tomar. Então, eu estava tendo ataque todos os dias, entendeu? Depois que entrei aqui, me levaram para o Hospital São Paulo, conversei com o médico e ele passou o remédio, não está dando mais crise. Toda a semana chama para o pré-natal, para ver como está o bebê, se está bem, se tem algum problema, então! Lá fora não, lá fora é todo o mês, aqui é toda a semana, te chama para fazer alguma coisa, ultrasom, eu, pelo menos eu gosto. Eu estou achando muito bom, melhor ainda porque eu voltei a tomar o meu remédio, não estava agüentando mais. Antes eu não saia na rua com medo de dar ataque. Não saia do portão de casa, não sabia o que ia acontecer. Agora eu saio, agora eu sei que não vou ter crise de novo, porque tomo o remédio. Era a vontade que eu tinha de tomar o remédio, né? Aqui eu consegui. Se eu estivesse lá fora, estava dando ataque até hoje. 


\section{DEPOIMENTO II}

\section{- Como era o seu dia-a-dia antes de vir para cá?}

Bom, minha vida antes de vir para cá era, ... Ah! Eu morava com a minha sogra, cuidava de meus dois filhos, né? Mais era muito difícil, o meu marido estava preso, ficou paraplégico (tomou um tiro), e acabei ficando na casa dela com os dois filhos, mas era muita briga (pausa). Mas não dava certo, eu estava muito cansada, aí aconteceu, eu fiquei grávida, escondi dois meses. Minha sogra descobriu e me pôs para fora, foi onde me indicaram aqui. Me pôs para fora em ambas as partes: primeiro, eu fiz uma besteira (ri). Aconteceu lá, fui visitar o meu marido e engravidei de outro lá. Eu tinha usado remédio para poder tirar a criança (permanganato), fui levada para o Hospital do Mandaqui e de lá vim para cá, onde as pessoas não têm aonde ir. E os meus filhos ficou com ela, com minha sogra e minha cunhada, e estou aqui há seis meses, quase seis meses. Ela me mandou embora, porque não é do meu marido. Eu engravidei de uma pessoa, porque o meu marido estava paraplégico. Então, ele não faz mais nada, aí como não é dele, ela me pôs para fora. E o pai do nenê, como era uma pessoa que também vivia nas droga, acabou não sei que diacho, acabaram matando ele também. A família dele queria o neném, mas toda a família mexe com droga. Então, eu tenho medo, não deixo. No caso se não tenho condiçães de cuidar do nenê, eu deixo ele aqui do que deixar com a família. Se fosse gente que tinha condição, eu não ia deixar aqui. Aí eu estou nesta sem destino, não sei o que eu faço, quando sai daqui não tenho como criar este menino lá fora. Então, o único jeito é deixar para adoção, é contra a minha vontade. Então, já que o pai faleceu! O pai também não era (pausa). Eu prefiro o pai dos meus dois filhos, do que deste aqui. Aconteceu por acaso, é que nós era ex-namorado, então, aconteceu. Não foi para prejudicar o meu marido lá dentro, a gente se fala. Eu fui lá esta semana, fui levar os meus filhos para ele vê. O meu filho mais velho tem cinco anos e o outro quatro; então, eles precisam ver o pai, ele não me xingou também, são coisas da vida. Nós decidimos ficar na maior amizade, pelo menos, por causa das crianças, nós tem duas criança. Já a minha sogra, não, ela é osso duro de roer, ela não gosta. Está magoada com razão, o filho dela do jeito que está e eu aprontei ... . Mas é o seguinte, a minha cunhada me apóia, ela não me discrimina, ficou chateada, mas quer que eu volte para 
cuidar dos meninos. É muito duro quando vou visitar, saio e deixo eles. Eles perguntam do bebê, se está na minha barriga, ficam perguntando. O que vou fazer quando eu voltar sem o bebê? Eles vão querer saber (ri). O pequeno, menor meu, está um pouco enciumado, é um grude! $O$ mais velho fica mexendo na barriga e perguntando. Eu não sei como explicar para eles, estou totalmente perdida. O pai fala que, quando eles crescerem, eles vão saber o que eu fiz, mas isto não tem como esconder, mas filho não perde amor da mãe! Eu falo não adianta nada, você jogar eles contra mim. Aí depois nós começou a se entender, acho melhor pelas crianças. Ele pergunta o que eu vou fazer com a criança, perguntou quem é o pai, eu falei. Contei o que aconteceu. Para esta criança não tem lugar, vou deixar para quem pode dar um futuro melhor, porque eu não vou ficar na rua com a criança. Eu vou sofrer se for para a rua e passar fome, deixar a criança num canto passando fome e frio ou na lata do lixo. Ninguém sabe sobre isto, só uma assistente social. Eu já dei as roupinhas para não ficar balançada, porque balança na hora. E outra, se fica aqui vai para o albergue e criança não é para ir para o albergue, albergue não é lugar de criar o filho. Se eu tivesse, pelo menos, um lugar. Porque ir para a minha sogra, eu não vou. A minha mãe não vive uma vida muito boa com o meu pai, ele não aceita. Ele só aceita eu sozinha sem nenhuma criança. Minha mãe não queria que eu fizesse isto, dar o neném. Achar gente que quer acha, mas estando aqui não pode, tem que deixar aqui. A pessoa acha que é fácil, né? Vai lá e pega o neném, mas não é assim. Eu não vou para a casa do meu pai, ele não quer os meus filhos, não aceita eu dentro de casa, eu não me rebaixo. A minha cunhada falou que vai falar com o pai dos meus filhos, para falar com a mãe cuidar do bebê. A minha sogra podia olhar até eu dar um jeito na minha vida. O pai deles fala, quem nunca errou que atire a primeira pedra, se ele não tivesse errado, não estaria na cadeira de rodas, com 22 anos condenado para o resto da vida. Se eu não tivesse engravidado ninguém ia saber. Minha sogra ficou magoada porque eu engravidei. Só que quando ele resolvia sair, ele saia, ele saiu com uma amiga minha e não me respeitou. Eu não estou pagando coma mesma moeda. A minha sogra sabia e escondeu de mim.

\section{- Qual era a sua expectativa ao vir para cá?}

Ah, antes de vir para cá, eu achava que era até bom para mim! Porque aqui dá a morada, se não tiver condições de ficar com o bebê, também, pode deixar o neném. 
Eu fiquei assim, não fiquei muito feliz de vir para cá. Eu fiquei sabendo algumas coisas pela minha irmã que teve o bebê aqui, que as coisas não era muito bom. As meninas aqui trabalha demais, as gestantes, sei lá, os outros humilhava elas. Era muita menina de rua, elas trabalhava até nove meses de gestação, então, eu ficava cismada, não tinha outro lugar. Não tem outro lugar, vou para lá, vou tentar, não posso ficar na rua, falavam que aqui pegavam as criança, não era legalizado, mas, neste ponto era legalizado.

\section{- Como é viver aqui neste período estando grávida?}

O primeiro dia que cheguei aqui era um inferno. Eu mesma não gostei, chorava muito com saudades dos meninos. Eu achei um absurdo, liguei para a minha mãe ... isto é pior que uma cadeia, não quero ficar aqui. As meninas aqui parece tudo louca, na época as meninas era meio chatinha. Aqui a gente trabalha, e tem coisa que gestante não quer é trabalhar. Até concordo, mas, de sábado e de domingo, (pausa) não tem descanso jamais. E outra, você é impedido de sair para a rua, você tem direito a uma saída por semana, isto aí não pode é contra a lei, impedir da pessoa sair. Aqui eu saio duas, três vezes por semana, porque eu tenho que levar o meu filho ao médico, as vezes, também se não deixarem eu faço um escândalo. Eu fiquei uma semana com depressão. Eu já tive depressão antes, fiquei com medo dela voltar. Eu não gosto de ficar falando de minha vida para os psicólogos, principalmente, para as assistentes sociais. Eu já falei com uma assistente social, mas falei mentira, às vezes, era verdade (ri). Eu não gosto de falar. Aqui é o fim do mundo! Eu só estou aqui por causa desta criança, se não eu já teria saído, como está perto, eu já estou aqui há quase seis meses, é, seis meses! Então, faço o possível de ficar no meu setor, mais sei lá. Você quer uma ajuda, conversar com alguém, e elas falam que não te ajuda. Eu acho que a assistente social é para ajudar a pessoa, só converso com uma, com as outras não. Conversei porque o meu filho ia ser operado e eu precisei sair. E tem mais, não pode dormir fora, perde a vaga também. Acho errado também, não é porque você dorme fora é que tem um lugar ... e se você dormir em um hospital? O médico dele é lá na Santa Casa, às vezes, ele atende quase às cinco horas da tarde, e até que eu levo embora para a casa. A favela é perigosa, tenho medo! Então, durmo na casa da comadre. Aqui é bom, porque tira as pessoas da rua, mas tem coisa que eu não concordo. Mas é muito bom por um lado; e, assim, estou até hoje aqui, mas vou fazer 
o que! Tenho vontade, de sair daqui o mais breve possível. Viver aqui com a gestação, neste lugar, fica com depressão, porque você não tem direito de sair. Não é pelo lugar, o lugar é bom, mas a convivência, tem muita exigência. Agora, viver aqui, eu vivo na solidão, porque no dia da visita, a minha mãe não pode vir me visitar. Minha cunhada não pode trazer os meus filhos aqui. Então, você fica o quê? Às vezes, a gente não está boa para trabalhar, e vem a monitora e coloca a gente para trabalhar. Os quartos abrem mais cedo, televisão eu não assisto, não consigo dormir. Esta criança minha vai nascer revoltada, porque eu sou muito revoltada aqui dentro. Eu acho que tudo que a gente sente, a gente passa para a criança. Eu fico mais nervosa aqui dentro do que lá fora. O lugar não é ruim, mas a convivência, as meninas vão embora, que você já conhecia. Aí você fica mais triste, da minha época só sobrou duas. Aí elas têm aonde ir, e aí, você sente vontade de ir embora. Eu fico doidinha para ir. Por que eu não ganho logo esta criança? Às vezes, eu desconto na criança (como assim?). Eu fico nervosa e ponho a culpa na criança, ele deve sentir, se você chora, ele chora também. Desde que eu cheguei aqui, é mágoa. Quando vou na minha mãe, fico nervosa, quando vejo os meus filho, e venho para cá, fico triste. A única coisa boa é a missa, que a gente reza e tenta acalmar a gente. E agora que estou no final da gravidez, aí sim que você está mais ansiosa. Tinha duas psicólogas que fazia atendimento, mas eu não gosto. Era em grupo, não gosto de estar falando de mim, as meninas comentam, e eu não vou mais. Ah, tem o individual, não sei como ninguém me colocou ... A gente tenta ir na assistente social, mas ela diz que não tem tempo. Então, pronto você fica isolada. É bom porque você tem comida, cobertor e banho, mas não está com a família, não está com ninguém. Aí tem os cursos, né? Curso é bom para distrair a mente, se não tivesse nada para distrair aqui, você ficava louca. Eu fiquei quatro meses no curso de culinária, porque eu quis. Eu gostei, tive o certificado e passei para o overloque, né? A não ser isto que a gente sente aqui, o lugar não é ruim, mas a gente se sente só, frágil neste período.

\section{- O que você pretende fazer quando você for embora?}

Quando eu for embora, eu queria ficar perto dos meus filhos, ver se conseguia um emprego, trabalhar para eles. Quando for embora, só eu, só eu, para eles. O pai deles não vai ter mais como trabalhar mais. Trabalhar, ganhar alguma coisa, comprar alguma coisa para morar, para ter eles de volta. A minha sogra tem aonde morar e eu 
não. Vou ter que caçar serviço, para depois cuidar deles. Se eu não tivesse os meus filhos, ficava em outro lugar, dormia no emprego. Vou ver se alguém me ajuda, porque é muito difícil arrumar um emprego, e se de repente eu sair daqui e não consegui nada, para a casa dos meus pais eu não volto.

- Como está sendo o cuidado à saúde que você recebe? Foi como você esperava?

Em relação ao tratamento de saúde aqui, eu acho bom. Tipo na parte do pré-natal eu acho muito bom, você não precisa ficar marcando consulta, se a gente esquece eles avisam, te analisa direitinho, é bem legal o pré-natal. Agora muito, muito, o que me magoou foi no CO (Centro de Parto Normal). Pelo que fiquei sabendo, que as mães têm filho até no banheiro. Eu acho que não é bem assim, esperar para a criança coroar para depois colocar na maca. Dizem que não é médico, são enfermeiras, se acontecer alguma coisa não são médicos, são enfermeiras, não podem fazer nada. Essa pessoa que teve o neném no banheiro, achei um absurdo! Você vai em outro hospital, ele fica em cima, se estiver pronto para nascer ele vai direto, aqui não, você ganha antes de ir. Alguns dias atrás uma ganhou no alojamento e aí? Às vezes, a gente não está muito bem, e eles acham que é frescura da gente. Eu estou seis meses aqui, e nunca subi lá em cima ... . Só subi uma vez, mas fui bem atendida, pela médica e pela enfermeira. Mas, às vezes, tem um estresse do médico. Em relação ao prénatal, é bem melhor. Pelo menos, elas estão ali, elas explicam as coisas para você, que você não sabe, tiram as dúvidas. Em relação às assistentes sociais, elas passam o remédio, para isso elas são boas. Na saúde é bom, pelo menos, isto tem que ser. Estando grávida, tão frágil, você não sabe a hora que está para ganhar, pode ter dez. filho, mas um é diferente do outro. Fora alguns errinhos ... (como assim?). O médico não sabe explicar o que a gestante tem (admissão), fizeram um monte de exame e não descobriram o que eu tinha. O médico do ultra-som me atendeu bem. Ah, não gosto de ser atendida pela estagiária. Elas perguntam tudo de novo, e machucam, não sabe o que falam. Elas ficam sozinhas com a gente, a enfermeira não fica junto, ela fala que tem outra coisa para fazer, e não dá para ficar o tempo todo. Eu não quero ser atendida mais pelas estagiárias. Mas de resto, o atendimento à saúde é bom. 


\section{DEPOIMENTO III}

\section{- Como era o seu dia-a-dia antes de vir para cá?}

Antes de vir para cá, eu saía demais, todo o final de semana estava saindo. Ficava direto fora de casa, ficava três dias fora de casa, mas aí uma vez, a última vez, eu descobri que estava grávida. Fiz exame, a minha mãe estava com raiva de mim, $e$ como a minha tia ganhou os três filhos dela aqui. Aí minha tia me trouxe para cá. A minha mãe estava com raiva e me mandou para cá. Antes eu ia na igreja, era evangélica. Aí depois eu quis sair, ia para baile, mas a minha mãe não deixava. Aí eu saía do mesmo jeito, saía dormia fora, bebia demais, usava droga. Mas graças a Deus! Não fiquei dependente, depois a minha mãe descobriu. Eu sempre tive um bom relacionamento com a minha família. Mas eles começaram a se distanciar. Contei para a minha mãe a verdade e ela me levou no Caps de Pirituba, para fazer o tratamento de droga, fiquei dois dias. Aí descobri que estava grávida. Aí minha tia me trouxe para cá. Eu ficava dois dias fora, fiquei vinte dias só saindo, eu não voltava para casa. Eu pedia para o meu tio me buscar, fiz isso três vezes. Aí minha mãe foi me buscar, eu estava na casa de uma colega, era tipo uma favela. Eu estava bebendo demais, ela me trouxe para casa para eu me tratar. Eu tenho um irmão de dois anos, é como se ele fosse meu filho, quando eu trabalhava comprava coisa para ele. Eu sou muito apegada a ele, e ele também, às vezes, até demais. Às vezes, eu tinha vontade de voltar pelo meu irmão, mas tinha vergonha, porque ficava muito tempo fora. Meu pai é separado da minha mãe, eu não me dou bem com ele. Ele é alcoólatra e fica agressivo, bate na minha mãe. Quando ele bebia, ele vinha em cima de mim. Ele mora lá em Itaquera. Ele vinha ficava uma semana e depois ia embora. Toda vez que ele bebe, ele desconta em mim. Ele me bateu grávida. Ele queria que eu tratasse como pai, e eu não trato como pai, ele fica bravo. Eu trabalhava, fui trabalhar com 14 anos, trabalhava na padaria, acordava às cinco e meia da manhã. Eu era a que trabalhava mais e que ganhava menos. Trabalhava como babá.

\section{- Qual era a sua expectativa ao vir para cá?}

Minha expectativa era de mudar, né? Aqui têm as regras, não ia poder beber, não ter contato com as drogas, não poderia sair, sabia que eu não ia pode fazer toda as coisa. 


\section{- Como é viver aqui neste período estando grávida?}

Logo que eu cheguei, de dia eu fazia amizade com as pessoas, cada um tem um jeito. Mas à noite sempre batia uma angústia, de tudo o que você fez. Minha mãe ficava me procurando na favela, ficava lembrando que fiz a minha mãe sofrer. Não era para ter acontecido isto comigo, do jeito que a minha mãe me criou. À noite ficava angustiada, chorava toda a noite, não por causa do lugar, mas porque eu lembrava o que tinha feito para a minha mãe. Ficava com saudades, só que não vou voltar, porque a minha mãe não vai acreditar em mim. Então, eu vou ficar aqui. Então, de dia eu conversava com as outras me desabafava, não tinha medo do parto, porque aqui todo mundo estava grávida. Então, não sente medo, tudo o que acontece com você, não sente medo. E aqui ainda a gente trabalha, não tem tempo de parar, assim não dá tempo de pensar outras coisas. Só pensa em bebê, o dia todo em bebê. Só a noite quando deito a cabeça no travesseiro fico triste pensando no meu irmão. Eu ganhava as fraldas aqui, e guardava para o meu irmão. Todo sábado a minha mãe vem me visitar, ela fala que está chateada, mas ela vem me visitar, um dia que ela não veio no sábado, eu comecei a chorar. Por mais que eu achava que ela tinha largado mão, ela vinha me visitar, aí eu ficava melhor. Aí teve o dia primeiro de maio, teve um show na Avenida Paulista, só que acabou tarde para eu voltar. Aí fui dormir na casa de uma amiga em São Miguel. Cheguei no dia seguinte cedo, e aqui não pode dormir fora. Aí mandaram a gente embora, aí eu fui na minha casa. Só que a minha mãe ficou com medo que eu fizesse a mesma coisa. Aí quando estava de oito para nove meses, aí liguei para a assistente social, para ela deixar eu voltar. Quando estava na minha casa, eu já não tinha vontade de beber, estava melhor, nem de sair, fiquei três meses fora, ficava com a minha mãe.

\section{- O que você pretende fazer quando for embora?}

A primeira coisa, até quatro meses, vou ficar em casa, porque a minha mãe está desempregada. Ela faz faxina, tem que pagar aluguel. Depois, colocar na creche e procurar um serviço, para poder comprar as coisas para ela e para o meu irmão. Já que o meu pai não dá nada, vou cuidar do meu irmão e da minha filha. 


\section{- Como está sendo o cuidado à saúde que você recebe? Foi como você esperava?}

Os médicos era muito bom, mas eu não pensei que tivesse tantas coisas, aqui tem muitas coisas. Desde que cheguei já fizeram minha carteirinha do pré-natal, aí eu já passei no pré-natal. Fora que eu fazia fisioterapia, terapia ocupacional, passava com a psicóloga, pré-natal, tudo direitinho. No Papanicolaou, deu um probleminha, aí mandaram para o IBCC (Instituto Brasileiro de Controle do Câncer). Me tratei no IBCC, pagaram um remédio para passar, tudo que precisei fora, eles mandaram comprar. Quando subi no CO (Centro de Parto Normal) estava com três dedos de dilatação. Aí eu fiquei, tinha um monte de profissionais, monte de estudante, as médicas. Não deixam sozinhas, tinha um monte de doulas. Tinha três doulas comigo até ganhar o bebê, eu fiquei bem tranqüila. Eu só senti contração quando estava com sete centímetros de dilatação, não senti nada, ficava conversando, aí a gente se distrai, as médicas um amor de pessoa (Enfermeiras Obstétricas do Centro de Parto Normal). No pré-natal, é muito legal, tratam a gente muito bem, não tratam com diferença por ser do alojamento social, tem pessoal que pode tratar com diferença por ser do social, é como se estivesse pagando.

\section{DEPOIMENTO IV}

\section{- Como era o seu dia-a-dia antes de vir para cá?}

Eu não me dava muito bem com os meus pais adotivos, eu acabei indo morar com ele (pai da criança). Foi um pouco difícil, porque ele começou a entrar com as drogas, influência de amigos. Foi bem difícil, bem difíci! Agora aqui está bem sossegado. Lá fora estava bem complicado mesmo. A minha convivência na minha casa não era boa, o problema era comigo, porque sempre tinha um motivo para brigar, com o meu irmão não, com o meu irmão era sempre mais calmo. Aí eu não ficava muito em casa; eu ia para a casa de alguns amigos, na escola era tudo bem, tudo normal. Em casa, cada um pensa de um jeito, meio diferente de pensar. Então, acabava saindo conflito. Os meus pais biológicos eu queria conhecer. Tenho muita vontade de conhecer. $O$ meu relacionamento com o meu irmão, não era muito bom. A gente não se fala muito não, era só o básico, também, só o necessário. O pai era mais aberto, mas, não 
totalmente. Eles não dão espaço para a gente conversar. Eles já são de idade, então, tudo para ele parece estar errado, pessoa bem antiga mesmo. Não tinha muito diálogo, então, eu conversava mais com uma amiga, com parente também não, madrinha, tia são muito ocupado sabe! Trabalham, os filhos fazem faculdade, então, com a família não tenho diálogo. Eu tenho uma amiga que mora do lado do prédio do meu pai, praticamente nós crescemos juntas. Então, a gente conversa muito, sempre ela me dá força, ela vem me ver, me visitar. Atualmente ela não está vindo, ela tem o compromisso dela. Mas ela me dá conselhos, ela já conhece os meus pais tudo. Então, ela pode falar, dá conselhos. O pai da criança começou a usar drogas, eu não sabia. Percebi quando fiquei grávida. Acho que ele começou a usar drogas só depois da gravidez, ele ficava agressivo comigo, mas ele não era, foi depois da gravidez, então não dá para ficar com ele.

\section{- Qual era a sua expectativa ao vir para cá?}

Atingir aos meus objetivos, o objetivo que eu tinha era vir para cá, era de não ficar na rua, ficar por ai andando grávida, né? Então, eu vim pedir ajuda na igreja e eles me indicaram para cá. Tudo para mim não ficar na rua, né? Tudo para eu ter um lugar por enquanto, para arrumar um serviço.

\section{- Como é viver aqui neste período estando grávida?}

Bom, viver aqui, ah, é muito bom! A gente tem ajuda da assistente social, do pessoal da pastoral da escuta, das doulas. Aqui é muito bom, aqui ajuda bastante. Eu acho assim, aqui é um aprendizado de vida. É a primeira vez que eu estou precisando, então, várias histórias que a gente escuta. Cada uma com uma educação diferente sabe! Então, há quatro meses que estou aqui, eu nuca tive inimizade com ninguém, sempre escutei, sempre. Aqui é muito bom, tem ajuda de tudo. Tudo que a gente precisa a gente tem. Eu não conhecia, primeira vez que eu estou aqui, precisando. Por ser minha primeira gestação, eu estou muito bem, graças a Deus! Tem os médicos do pré-natal, falam que está tudo bem com o bebê. O meu espírito está mais calmo, do que se estivesse lá fora. Se eu estivesse lá fora, eu ia passar uma gestação muito nervosa. Ah! Como eu ia fazer, estaria pensando mil coisas, mas não. Aqui a minha gestação está sendo bem calma, estou bem tranqüila em tudo. O pessoal está tudo bem! O meu relacionamento está tudo bem, eu não tenho o que reclamar, eles 
não têm o que reclamar. Graças a Deus quando eu passo no pré-natal a médica (enfermeira obstétrica) fala, a paciente que não tem reclamação.

- O que você pretende fazer quando for embora?

Quando for embora, eu pretendo amamentar, né? Dar o período certo, depois de amamentar vou deixar na creche e ir trabalhar. Porque eu já estou acostumada a ir trabalhar. Então, ficar parada, eu não vou conseguir. Quero ter minhas coisinhas, toda a menina aqui dentro sonha em ter seu cantinho, suas coisinhas para poder cuidar. Muitas meninas acham que com o filho não pode fazer mais nada. Não, não acabou. Na minha maneira de pensar, é bem próprio. Eu vou colocar na creche, trabalhar e viver a minha vida. Eu, o meu filho e o meu marido. O pai do meu filho, eu estou com ele. Ele veio me visitar, ele ficou internado por droga, foi por causa dos amigos ou família dele, que não dão apoio. Então, ele estava sem serviço, mas ele é muito atencioso. Ele vem, ele quer saber do pré-natal, como eu estou, como está o neném. Ele está em albergue, está procurando serviço. Aí quando ele arrumar um lugar, eu vou morar com ele, eu vou morar com ele, com ele.

- Como está sendo o cuidado à saúde que você recebe? Foi como você esperava?

A assistência de saúde aqui, eles são bem atenciosos, é como eu esperava. Lá fora a gente não tem o tratamento que tem aqui. A gente não tem como usar o hospital particular, é público. Lá demora, as pessoas não ligam, aqui dão atenção adequada. Eu acho, bem adequado, bem atencioso, qualquer probleminha que surge, eles te escutam, ouvem, já tomam providência. As pessoas que ouvem, são as estagiárias, as médicas.

\section{DEPOIMENTO V}

\section{- Como era o seu dia-a-dia antes de vir para cá?}

Era bom, não trabalhava. Ficava em casa com minha filha, minha mãe nunca mandou eu ir trabalhar, tinha de tudo. A minha vida era assim, tudo que eu pedia para ela, ela me dava. Ela sempre me ajudou, não mandava eu trabalhar. Eu morava com o pai dela, aí eu engravidei, mas eu não gostava da mãe dele. Aí ele ficou comigo cinco meses, aí fui para casa e minha mãe ficou comigo. Eu conheci o pai dela (filho em gestação), ele é peruano, gringo, eu conheci no centro da cidade. Aí começamos a 
namorar, aí engravidei dele. Aí falei que estava grávida, e ele falou que não era dele. Aí a minha mãe ficou atrás dele, e ele falou para não ir atrás dele, se não ele ia fazer alguma coisa com a gente. Aí minha mãe me colocou para fora de casa, e eu vim para o Amparo Maternal. A minha família não queria que eu ficasse com ele, aí a minha mãe falou, não fica com ele e a minha vó falou não fica com ele. Este homem não presta, aí eu vi que não estava dando jeito. A família falou para mim tirar a criança, deve tomar remédio. Aí eu falei que não ia tirar o neném. Vou ficar com o meu filho. Eu falei para ele que ia ficar com o meu filho, e ele falou que não queria, que não era dele, que eu estava mentindo para segurar ele. Aí o meu padrasto me colocou na rua e a minha mãe, também. Aí eu fui atrás dele e ele falou que eu não ia morar com ele nada, que eu estava enganada que poderia ser de um monte de gente. Aí fiquei chateada e fui embora. Eu estava chorando na praça da Sé. Aí veio uma moça perguntou se eu estava passando mal. Eu falei tudo para ela, e ela me encaminhou para o Amparo. Eu antes estudava, fazia o supletivo na Lapa, mas aí eu comecei a faltar. Abandonei a escola, comecei para a balada, saia na terça voltava só no domingo. Minha mãe ficava preocupada comigo, então, eu mesmo me prejudiquei. Quando conheci ele (pai da criança), não queria mais ficar com a minha mãe $e$ comecei a fumar cigarro. Eu andava com o pai da minha filha e comecei a fumar crack. Aí eu estava com a minha prima e os peruanos, aí nós começamo a fumar e a beber. Aí neste dia, eu cheguei na minha casa, e minha mãe viu que eu estava muito estranha. Minha mãe disse: você não fumou cigarro! Fumou outra coisa. Aí minha prima disse nós usamo droga. Minha mãe me bateu e colocou para fora, fui para a casa de minha vó, e continuei usando droga. Eles queriam me internar, eu disse não, não sou viciada! O pai da criança foi atrás de mim e falou pra trabalhar com ele. Ele roubava e colocava a mercadoria no carro e nós vendia celular roubado. Mas a polícia viu ele roubando e prenderam ele. Aí apareceu a mulher dele e perguntou se eu estava com o marido dela, eu disse que não! O pai desse filho disse que queria ter um filho aqui no Brasil, para poder ficar no Brasil. Aí como eu estava muito apaixonada, eu engravidei aí ele falou que não era dele.

\section{- Qual era a sua expectativa ao vir para cá?}

Quando eu falei para a mulher que eu estava mal, ela falou do Amparo, se eu queria ir para lá, fica um monte de mulheres grávidas. Aí ela me colocou no carro, falou que 
aqui era bom, tinha maternidade. Eles davam o enxoval. No começo, eu fiquei chorando, porque nunca tinha passado por isso, passava mal direto. Eu subia e as assistente social falava comigo que aqui tem que se acostumar, que era muito bom. Agora eu gosto já me acostumei.

\section{- Como é viver aqui neste período estando grávida?}

Viver aqui não é fácil para ninguém. A gente fica presa, parece um tipo presídio. Mas tem muitas meninas que não pode falar nada, se brigar a gente vai embora. Para mim, no começo não estava agüentando, mas agora eu tenho que agradecer o Amparo, porque ele me recebeu de braços aberto. Tudo o que eu fiz aqui dentro, eles estavam do meu lado (profissionais), ganhei muitas coisa, eles falavam que iam me ajudar. Eu acho aqui bom, a gente não tem para onde ir. No começo eu brigava mais, a assistente social dizia que eu ia embora. Se não fosse eles o meu filho não estava mais vivo, se estivesse na rua não tinha o que comer, e aqui no Amparo tem. Não ia ter como tomar banho, me cobrir, como comer, a criança quando a mãe não como ela não come, eu ia ter ela na rua.

\section{- O que você pretende fazer quando for embora?}

Quando for embora com a minha filha, vou arrumar um serviço para mim. Vou pagar minha irmã para cuidar dela, e depois ela vai para a creche. Vou trabalhar, cuidar de minhas filhas, ajudar a minha mãe. Se minha filha perguntar do pai vou dizer que ele morreu (sorri). Vou ser pai e mãe dela.

- Como está sendo o cuidado à saúde que você recebe? Foi como você esperava?

Quando cheguei aqui, eles fizeram todos os exames, marcaram pré-natal, me deram remédio. Não precisei comprar, eles me trataram bem. Eles viram que eu estava com anemia profunda, eles me cuidaram da minha anemia no pré-natal, me deram um remédio bom. Se eu estivesse na rua não ia fazer o pré-natal, n?, Minha anemia está curada. 


\section{DEPOIMENTO VI}

\section{- Como era o seu dia-a-dia antes de vir para cá?}

Não era muito bom, porque eu usava drogas. Na época, até os seis meses usei drogas, vivia na rua, usando drogas, estava na clínica para não usar drogas. Aí eu fugi e vim para cá. Agora estou melhor, não estou usando droga, coloquei na minha cabeça que eu quero mudar mesmo. Eu saí de casa nova, eu tinha 15 anos. Aí a minha mãe falou ou você vai para a igreja Testemunho de Jeová, ou para casa. Aí eu vim para a rua, ficava na rua usava droga, fiquei três anos na Bahia, tive um filho. Vim para São Paulo, comecei a usar o crack e engravidei de minha outra filha. Depois um ano e pouco, engravidei de novo na rua de um cara, mataram o cara, eu perdi o neném, e engravidei deste. A minha família perdeu a confiança. Acredito, agora que eles estão vendo que eu estou querendo mudar, estão me dando voto de confiança.

\section{- Qual era a sua expectativa ao vir para cá?}

Bom, a expectativa de vim para cá é de ter uma vida diferente de vida, melhor, e de parar de usar droga. Se eu continuasse com esta vida que eu estava, eu ia morrer e matar o meu filho. Então, aqui tem ajuda para mudar, aqui tem bastante coisa para fazer, na clínica onde eu estava, só tinha Deus. Só falavam em Deus, aqui está sendo muito melhor.

\section{- Como é viver aqui neste período estando grávida?}

Está sendo bom e está sendo ruim, porque as meninas, às vezes, arrumam encrenca, fofoca. Está sendo bom, porque não falta nada para mim, para o meu filho. Fora as encrencas e as fofocas, é ótimo. Ficar aqui grávida não é bom, a gente fica muito carente, e eles tratam todo mundo igual. Então, qualquer dor que a gente sente é ignorado, acham que é fingimento. Quando está gestante é uma coisa, quando vira mãe fica mais fácil, separa das meninas, fica só em contato com o filho, não fica pensando em outra coisa.

\section{- O que você pretende fazer quando for embora?}

Quando eu sair, eu quero arrumar um trabalho, casa, e os meus filhos de volta, sinto muita falta deles. Eles moram com a minha vó, quero arrumar uma casa e arrumar trabalho, porque senão vou voltar para esta vida de novo. 


\section{- Como está sendo o cuidado à saúde que você recebe? Foi como você esperava?}

Eu não esperava que ia ser assim, é muito boa! Lá fora passa uma vez por mês, aqui deixa o remédio se não tem eles compram, se tiver outros problemas a mais eles mandam para outro hospital. Outro lugar para fazer exame, aí tem o pré-natal uma vez por mês. No final, uma vez por semana. É muito bom, mas tipo assim, lá em cima eles nem examinam direito. Eles sabem que a gente é do alojamento, eles acham que a gente não tem nada, às vezes, porque uma vai por qualquer coisa, as outras pagam.

\section{DEPOIMENTO VII}

\section{- Como era o seu dia-a-dia antes de vir para cá?}

Bom, o meu dia-a-dia, eu trabalhava em uma casa de família, tomava conta da casa, eu não era de sair não. Era normal, eu morava no serviço, eu fazia tudo, depois que eu fiquei grávida eu sai de lá. No final de semana, eu ia ver o meu filho que mora com uma prima. Eu não tenho marido, aqui em São Paulo, eu não tenho família não, porque meu pai mora na Bahia. Tem esta prima minha que é prima de meu pai que é aqui de São Paulo. Os meus irmãos também moram na Bahia, eu fui criada pela minha vó. Quando ela morreu, eu fui morar com a minha tia, e depois ela mandou eu morar com o meu pai, quando eu tinha 14 anos. Aí eu fiquei um tempo lá na Bahia, e quando eu tinha 19 anos eu vim para cá. Estou até agora aqui, só trabalhando na casa de família. E, nesta, eu conheci o pai da minha filha (gestando), ele trabalha perto da loja de minha patroa. Eu conheci ele lá, comecei sair com ele e aí engravidei. Aí eu pensei em abortar, aí ele foi contra. Aí eu acabei aceitando, né? Aí eu tipo assim, eu estava trabalhando, aí minha patroa estava em situação financeira ruim e eu não pude ficar lá. Não podia me pagar. Ela nem sabia que eu estava grávida porque eu escondi. Aí eu falei para ela e ela disse, eu não vou ficar contigo. Aí eu me informei na igreja e eles falaram que tinha esta instituição que ajudam mulheres grávidas, aí eu vim para cá, eu estava com sete meses de gestação.

\section{- Qual era a sua expectativa ao vir para cá?}

A minha prima já cuida do meu filho, então, ela não queria que eu fosse para lá (na casa da prima). A casa dela era pequena, o marido dela sustenta ela. Aí eu vim, 
conheci aqui, conversei com a assistente social e vim para cá, eu gostei muito daqui, agora eu vou embora dia vinte, então, vou continuar minha vida.

\section{- Como é viver aqui neste período estando grávida?}

Viver aqui você aprende muita coisa, porque você convive com muitas pessoas. Eu não era acostumada a viver com muitas pessoas, muitas mulheres, dividir banheiro tudo mais. Para mim, foi muito bom assim, é bom aqui, os cursos! Tinha dias que a gente ficava triste, porque estava longe de todos. Todo mundo, da família, pai, do meu filho, mas sempre tem alguém para conversar. As assistentes sociais dão atenção, as irmãs, as pessoas do pré-natal, as enfermeiras dão toda atenção. Tudo para mim foi bom, foi uma lição de vida, porque eu mesma não achava que ia conseguir viver no meio de muitas mulheres, porque eu tenho o gênio meio forte. Então, você acaba aceitando o que não estava acostumada aceitar. Você acaba aprendendo a respeitar, cada um tem uma opinião, então, para mim foi bom. Só que estando aqui, eu vejo o meu filho uma vez por semana. E lá fora, a hora que eu quiser ver o meu filho, eu posso. Aqui tem hora para tudo, tem hora para chegar e para sair. Eu sinto saudades do meu filho, do meu filho! Tudo que a gente precisa, tem sempre alguém para te guiar, sendo que lá fora não tem isso e aqui tem o cuidado, já que a gente está gestante.

\section{- O que você pretende fazer quando for embora?}

A minha expectativa agora que eu vou embora, né, dia 20, é trabalhar, cuidar dos meus filhos, principalmente, do neném, por ele ser pequeno. Eu pretendo ficar um tempo em São Paulo juntar alguma coisa, para eu poder ir embora, para perto do meu pai, dos meus irmãos, e ir pegar o meu filho que mora com a minha prima. Meu sonho é poder alugar uma casa e trabalhar de manhã e pegar ele à noite, porque eu vou voltar a trabalhar no serviço que eu estava. A minha patroa me chamou de volta, estava até triste, porque eu ia te que deixar com uma senhora. Então, minha patroa aceitou eu voltar e lá ficar com o bebê até ela mamar e estar maior. Aí vou arrumar um lugar para ela ficar ou deixar com esta senhora mesmo para tomar conta dela.

- Como está sendo o cuidado à saúde que você recebe? Foi como você esperava?

A saúde é nota dez! Porque dão muita atenção para a gente no pré-natal, a gente participava de muitas palestras, dúvidas que a gente tinha, eles esclareciam com a 
gente. Eu tive um problema de estômago, fui no Hospital São Paulo. Eles deram a medicação, me perguntavam sempre se estava bem, até sobre a alimentação eles perguntavam se eu queria mudar. Eu até mudei de alimentação, não tenho o que reclamar. Eles me tratam muito bem (olho lagrimejando). A estagiária do pré-natal, ela me tratou muito bem, me perguntava sobre o pai do bebê, sobre a minha filha. Eu não esperava que ia ser muito bom. Quando tive o meu primeiro filho, eu não tive esta assistência toda e aqui é bem melhor, no centro obstétrico (Centro de Parto Normal) a enfermeira foi excelente, deu atenção.

\section{DEPOIMENTO VIII}

\section{- Como era o seu dia-a-dia antes de vir para cá?}

Eu trabalhava, estudava. Era amigada, aí me separei e fui morar com a minha avó. Aí fique sabendo que estava grávida, voltei para o meu marido. Aí a gente brigamo e a minha madrasta não me aceitou em casa. A vida dela é só ela, o meu pai e meu irmão. Aí eu tive que vir para cá. O pai do meu filho não sabe que ele nasceu, não ficou sabendo que eu estava grávida. A relação com a minha família não era muito boa, eu era a ovelha negra da família, porque saia para as baladas e só voltava aos domingos, estudava à noite e todo dia era a mesma coisa. A minha família achava que tudo que eu fazia, era errado.

\section{- Qual era a sua expectativa ao vir para cá?}

Eu espero ter uma gestação boa, que o meu pai possa me ajudar, aí poder sustentar a minha filha.

\section{- Como é viver aqui neste período estando grávida?}

É difícil, porque tem muita menina! Aí é difícil conviver com pessoas diferentes. Acho que é legal, porque as assistentes sociais ajudam a gente. Elas ajudam a falar com o meu pai, porque eu achava que não tinha para aonde ir. Aí o meu pai conversou com a madrasta e vai me assumir. Eu sinto muita saudades de minha família. Eu gosto muito do meu irmão e do meu pai, são as duas pessoas que eu mais gosto, é difícil ficar aqui. 


\section{- O que você pretende fazer quando for embora?}

Pretendo colocar na creche, voltar a trabalhar e construir uma família, já que eu não pude ter minha família lá atrás. Eu posso ter agora, e quero contar para o pai dela que eu estava grávida, meu pai quer que eu vou atrás dele, para ele pagar a pensão.

- Como está sendo o cuidado à saúde que você recebeu? Foi como você esperava?

Foi bom, porque quando eu vim para o pré-natal, eu tinha medo de ter nenê. Recebi orientação da enfermeira, recebi ajuda. Quando subi na clínica (Centro de Parto Normal) a médica (enfermeira obstétrica) me atendeu com calma, conversou comigo me acalmando, aí foi bom! As doulas me ajudaram, a pastoral da escuta também me ajudou. Ajuda até agora, tinha um grupo de estagiários no pré-natal que orientava.

\section{DEPOIMENTO IX}

\section{- Como era o seu dia-a-dia antes de vir para cá?}

Eu morava com o pai da minha filha há dois anos. Engravidei e com cinco meses começaram as brigas. Começou brigar muito e nossa vida ficou difícil, ele mudou, ficou agressivo. Minha família mora longe no interior do Nordeste. O meu filho de 12 anos ficou com a minha mãe. O pai deste filho chegou me agrediu. Aí eu descobri aqui com uma amiga e resolvi ver como é.

\section{- Qual era a sua expectativa ao vir para cá?}

Eu achei que aqui era o lugar para ter o meu filho, queria ter minha alimentação, tranqüilidade.

\section{- Como é viver aqui neste período estando grávida?}

Embora algumas meninas acham que aqui tem que ter liberdade, eu não tenho o que falar. Eu gostei, tem as roupinhas, o médico, alimentação, remédio. Aqui dá saudades da família. A minha gravidez aqui foi tranqüila, fazia minhas tarefas, não ficava ansiosa, aqui foi o melhor, aqui apareceu como uma luz. Se não existisse este lugar, eu não sei o que teria feito.

- O que você pretende fazer quando for embora?

Procurar um serviço, pretendo ir embora com minha filha, cuidar de minha filha só. 


\section{- Como está sendo o cuidado à saúde que você recebe? Foi como você esperava?}

Nossa! Muito mais do que esperava, temos muitas opções. No pré-natal, foi ótimo, conversava, não era só uma consulta, desabafava, não tenho o que reclamar, que Deus conserve este lugar! Que as pessoas continue contribuindo!. O Centro Obstétrico foi ótimo, estava tranqüila, fui muito bem atendida, tive ajuda de uma voluntária carinhosa, ficou o tempo todo comigo. No Alojamento (Alojamento Conjunto) foi bom os estagiários (chorando). Estou emocionada. Às vezes, nós pensamos que temos muitos problemas, mas outras pessoas têm mais.

\section{DEPOIMENTO $\mathrm{X}$}

\section{- Como era o seu dia-a-dia antes de vir para cá?}

Minha vida antes era turbulenta, eu não sabia o que eu queria, confusa. Quando eu fiquei grávida eu não aceitei, porque não foi planejada, perdi emprego, curso. Era uma pessoa depressiva sem saber o que eu queria, em qualquer lugar que eu ficasse, poderia ser um palácio ou uma roça. Eu queria me esconder de todo mundo, ficar sozinha eu e meu filho. O Amparo Maternal me deu assim uma certeza psicológica, porque abalou o meu psicológico, tive muitas mudanças, fiquei muito inchada, acho que eu fiquei uma pessoa estranha, esquisita, antes de eu vir para cá estava bastante complicado. Posso dizer morta espiritualmente. O Amparo me trouxe uma alegria profunda, uma vontade de viver. Eu mal me olhava no espelho e, hoje, eu me encontrei, me sinto resolvida, concentrada. Quando eu fiquei grávida, eu não sabia se ia ficar com os meus pais, com o meu namorado, se ia procurar minha antiga patroa. Fiquei com vergonha de voltar para a minha família, porque eu era independente. Eu já morava fora há sete anos, fiquei com vergonha de procurar o meu pai e minha mãe. Eu queria enfrentar sozinha, mas não estava em condições, primeiro estava desempregada. Fiquei na casa de amigos, mas eu sentia que era um peso a mais. Por eu não estar trabalhando afetou o meu psicológico, eu joguei dinheiro fora, eu gastava muito. 


\section{- Qual era a sua expectativa ao vir para cá?}

Eu tinha trauma de hospital, depois comentavam que o Amparo maltratava as mãezinhas, gestantes. Tinha mal impressão, mas a minha expectativa é que ia me ajudar, mas por tudo que estava passando minha última opção era aqui. Mesmo que falasse positivo ou negativo. O que me dava mais medo é que estando aqui, eu ia passar nas mãos dos médicos. Minha maior expectativa era o medo dos médicos, expectativa das alojadas, mas resumindo, tive um bom atendimento, abriu muito a minha mente.

- Como é viver aqui neste período estando grávida?

Viver aqui grávida para mim não foi muito bom, porque estava inchada. Não conseguia fazer as atividades direito, nos cursos me complicava. Meu psicológico não estava bom, mas o lugar é muito bom, um lugar que tem todas as atividades, cursos. Aqui é como eu estivesse em casa, com um monte de irmãos, cada um com uma natureza, cada uma tem uma religião, cada um vê a vida com um sentido, cada um com um exemplo de vida. Depois tudo passa, a rivalidade passa depois que tem o filho. O centro de tudo é o seu filho. Eu queria o pai do meu filho para vir me visitar, está longe da família é muito dolorido, dá muita dor no coração, tremores. A partir do momento que você é mãe, dá muita coragem de mostrar para o pai que você é suficiente de lidar com a sua situação. Na calada da noite, aquele horário que você está com a sua mãe, aqui a gente parece que está em casa, mas só vê gente barriguda. Aqui teve uma eleição e a barriga mais bonita foi a minha, e eu me considerava a mais feia. Aqui, do lado religioso é como eu estivesse sendo lapidada.

\section{- O que você pretende fazer quando for embora?}

Pretendo voltar a trabalhar como cabeleireira, alugar uma casa, viver individualmente eи е meu filho, fazer supletivo, tirar minha carta de motorista. Tenho uma visão do meu futuro bem brilhante, bem mais brilhante do que antes. Eu sempre traçava os meus objetivos e nunca concluía. Agora, os meus sonho é mais colorido do que antes. Para este menino tenho vários sonhos, não dá para falar, me arrependi de ter tido pensamento negativo durante a gestação. Tenho que ter minha responsabilidade como cuidar, com quem deixar, meu futuro será muito brilhante. 
- Como está sendo o cuidado à saúde que você recebe? Foi como você esperava?

Da saúde, só tenho a agradecer, principalmente, da saúde psicológica, que é uma parte muito importante do nosso corpo, porque se o psicológico não estiver bom, o resto não vai estar bom. Tive pressão alta, tive ajuda, boa alimentação. Tive boas psicólogas, principalmente, uma me ajudou a encarar a gravidez como algo normal. Fui muito bem recebida e acho que abusei um pouco, comia três pães de manhã. Meu filho nasceu bem grande. Chorei um pouco quando vi o meu corpo, mas o meu filho está com saúde, então, estou feliz, choro de emoção. 